\title{
ELECTORAL REFORM AND THE CENTRALISATION OF THE NEW ZEALAND NATIONAL PARTY.
}

\author{
GREGORY R. STEPHENS
}

A thesis submitted in fulfilment of the requirements for the degree of Master of Arts in Political Science at Victoria University of Wellington.

May 2008 


\begin{abstract}
Political party organisations respond to the challenges of their environments. Different organisational structures have different capabilities and capacities and, therefore, some organisations are better suited to some environments. What happened to party organisations when New Zealand changed from a first-past-the-post to a mixed member proportional electoral system? Did all parties have the same capacities to meet the challenges raised by this new environment?
\end{abstract}

This paper addresses these questions by examining the organisational responses of the New Zealand National Party to the introduction of the mixed member proportional electoral system after 1993. The National Party was constructed to operate in a firstpast-the-post electoral system and it did so successfully, winning twelve of the nineteen elections it contested. In response to the challenges of the first-past-the-post environment, National decentralised both candidate selection and campaign structure. National's decentralised organisation proved to be a liability for National under the new mixed member proportional environment however. Mixed member proportional demanded the construction of a nationwide list and a coherent campaign for the nationwide party vote. With its existing organisational structure, National was unable to meet either of these demands and suffered the electoral repercussions of that failure. After four consecutive elections in which National lost vote share, the National Party centralised its organisation in 2003.

This paper analyses the centralisation of the National Party organisation - and the reasons for it - by examining the Party's efforts to reform candidate selection and management of campaigns. The two organisational structures which National used for 
selecting candidates and managing campaigns under mixed member proportional produced different results. The candidate pools for 1996, 1999 and 2002 failed to provide nationwide appeal and produced incentive for electorate candidates to ignore the party vote element. Further, the campaign structure for these three elections allowed electorate committees significant control and the ability to undermine the nationwide party vote campaign. In the 2005 election, however, candidate selection and campaign management showed significant changes. The candidate selection process provided incentives for electorate candidates to seek both electorate and party votes, although it arguably still failed to produce a nationally appealing party list. The management of the campaign was also significantly different. It demonstrated the benefit of central campaign control in a mixed member proportional electoral system. The 2003 centralisation gave National elites significant control and allowed National to almost double its 2002 result in the 2005 election. This thesis demonstrates that a mixed member proportional electoral system gave National strong incentives to centralise its party organisation. 


\section{Acknowledgements}

There are many people to whom I need to thank for their contribution to this thesis. They have all contributed in their own way and for any person to whom I miss out I thus apologise.

I extend a sincere thank you to my three interview subjects, for both their time and knowledge. I have kept their names and views anonymous in this thesis in order to allow them to say whatever they wanted on the internal politics of the National Party without fear of any repercussion or media analysis. Needless to say, they are all members of the National Party elite. Their insights are found throughout this thesis. I hope that none feels that their words were misconstrued, and if so, I apologise.

My two thesis supervisors deserve much credit for what they have brought to the table. Professor Elizabeth McLeay has shared her substantial knowledge of New Zealand politics and parties as well as pulling many source documents out of her filing cabinet and books of her shelves. Dr. John Leslie was able to provide his knowledge of the international and theoretical political party literature and also raised interesting questions from an outsider's perspective. The synergy of two thesis supervisors has worked well and has meant lively discussion on a regular basis. I am very thankful for the hard work of John and Elizabeth.

Other staff in Victoria University of Wellington's Political Science and International Relations Programme also deserve thanks. Professor Nigel S. Roberts kindly provided pictures of billboards and advice on electoral systems. Dr. Jon Johansson has been

willing to talk about National Party events and history. Dr. Margaret Hayward has 
discussed some of the insights she gained from her PhD thesis. Professor Margaret Clark, Dr. Pat Maloney and Dr. Chris Eichbaum (the latter of the School of Government) all deserve thanks for providing tutoring and/or research work and hence money in my bank account - Margaret and Chris have also provided insights into New Zealand politics and political parties.

Isaac Newton noted that "if I have seen further it is by standing on the shoulders of Giants." Two works in particular have eased the writing of this thesis - although many others have as well. Barry Gustafson's The First 50 Years: A History of the New Zealand National Party (Auckland: Reed Methuen, 1986) provided many insightful tips on National's organisation and history. Nicky Hager's The Hollow Men: A Study in the Politics of Deception (Nelson: Craig Potton Publishing, 2006) also helped by providing an unprecedented insight into the operation of the National Party. These two works have provided many useful insights into the National Party and have eased the writing of this thesis.

Finally, I would like to thank those that have kept me sane while I write this thesis. My partner, Nicky Scott, has been wonderful and supportive - she has ensured I take breaks and also read through each and every chapter making sure the spelling, grammar and style are all correct. My parents, Bob and Alison Stephens, have provided food parcels as well as reading this work and paying for the university fees. My sisters, Andréa and Cielle Stephens, set the way for doing my thesis as both have done theirs previously so I knew what I was getting in for. Many thanks to my friends, who are too numerous to list, for getting me out of my office and for accepting that sometimes I was not in the mood to party. My fellow thesis students have been a great help in discussing my 
work, having regular lunches and drinks together and for providing endless entertainment - some have also contributed to a chapter editing exchange programme. While the contributions do vary, all of these people deserve thanks for their support.

It is a standard academic convention to state that while these people have provided help and information, all faults are of my own. While I would like to transfer all responsibility for mistakes to someone else, unfortunately they do lie with myself. The facts presented in this thesis are, to the best of my knowledge, indeed the truth. Any mistakes are regretted and accidental.

And thanks must also be extended to you, the reader. I hope that the following helps you in your own research. Enjoy! 


\section{$\underline{\text { Table of Contents }}$}

Chapter One: Introduction

Knowledge Gained

Layout of Thesis

Chapter Two: The Impact of Electoral Reform on Party Organisation

The Impact of Electoral Systems on Party Organisation

Candidate Selection

Campaign Structure

Challenges for Analysis

Centralisation as a Response to Decline 21

Centralisation as a Response to Internal Instability 22

Centralisation as a Movement towards the Cartel Model 23

Parties Undergoing Electoral Reform 25

Chapter Three: The New Zealand National Party $\quad 27$

History

Formation

The Natural Party of Government, 1949-1984 30

Liberalisation and Realignment, 1984-1993 32

Ideological Factionalism

Organisation 39

Party Executive $\quad 39$

Regional Divisions $\quad 41$

Social Divisions $\quad 43$

Membership $\quad 45$

Caucus Separation $\quad 47$

Electorate Candidate Selection $\quad 49$

Preparations for MMP 51

The New Zealand National Party under FPP 53

Chapter Four: Defeat and Decline Under MMP $\quad \mathbf{5 6}$

Decline, 1996-2002 56

Explaining the Decline $\quad 61$

MMP Factors $\quad 61$

Concurrent Factors $\quad 64$

Organisational Factors $\quad 71$

Reviews of Organisation 78

1997 Review and Minor Re-Organisation $\quad 79$

2003 Review and Centralisation $\quad 82$

Decline and Re-Organisation $\quad 86$

Chapter Five: Candidate Selection $\quad \mathbf{8 8}$

1996, 1999 and 2002 Candidate Selection Outcomes $\quad 89$

2003 Changes 95

Candidate's Club 95

List Nomination Process

List Selectorate $\quad 99$

2005 Candidate Selection 101

Candidates' College 101

No Māori Seat Candidates 104

List Outcome 106

Unfinished Business in Candidate Selection 111 
Chapter Six: Campaigning

Decentralised Campaigning in an MMP Environment 115

Financing Campaigns 116

Rejection of Professionalisation $\quad 118$

Lack of Strategy 120

Un-Coordinated Advertising $\quad 122$

Re-Organisation 126

Finance 126

$\begin{array}{ll}\text { Professionalisation } & 127\end{array}$

$\begin{array}{ll}\text { Control Over Strategy } & 129\end{array}$

Control over Advertising 131

2005 Election Campaign 132

$\begin{array}{lr}\text { Corporate Finance } & 132\end{array}$

Professional Advisers 134

Multiple Strategies for the Party Vote 136

Consistent Advertising 146

The 2005 Election 153

Chapter Seven: Conclusion $\quad 158$

\begin{tabular}{ll}
\hline Electoral Systems and Party Organisation & 159
\end{tabular}

$\begin{array}{ll}\text { Future Challenges for National } & 161\end{array}$

Conclusion 163

Appendix One: Organisation and Candidate Selection Charts $\quad \mathbf{1 6 4}$

1985-1997 Organisation 165

1997-2003 Organisation 166

2003- Organisation 167

1973-1995 Candidate Selection 168

1995-2003 Candidate Selection 169

2003- Candidate Selection 170

Appendix Two: National Party Candidates 1996-2005 171

\begin{tabular}{ll}
1996 Election & 171 \\
\hline
\end{tabular}

1999 Election 173

2002 Election $\quad 175$

2005 Election 177

Appendix Three: Estimated Number of Party Members $\quad 179$

$\begin{array}{ll}\text { Sources } & 180\end{array}$

$\begin{array}{lc}\text { Bibliography } & 182\end{array}$ 


\section{List of Tables and Figures}

Figure 3.1 National Party Valid Vote Share under FPP, 1938-1993 34

Table 3.1 The Factional/Ideological position of National's Leaders 37

Table 3.2 The Factional/Ideological position of Leader and Deputy Leader $\quad 38$

Table 3.3 Women Candidates in National and Labour, 1946 to 1993

Figure 4.1 National Party Valid Vote Share 1990-2002 60

Figure 4.2 Labour Party Valid Vote Share 1935-2005 63

Figure 4.3 Public Trust in the New Zealand National Party 66

Figure 4.4 Indexed Declining Vote Share of Governments $\quad 70$

Figure 4.5 New Zealand Political Spectrum (post-2002 election) 77

Table 5.1 1996 National Candidate Pool 91

Table 5.2 1999 National Candidate Pool 92

Table 5.32002 National Candidate Pool 93

$\begin{array}{ll}\text { Table 5.4 2005 National Candidate Pool } & 109\end{array}$

Figure 6.12002 National Electorate Billboards 123

$\begin{array}{ll}\text { Figure 6.2 National Party 'Iwi/Kiwi’ Billboard } & 143\end{array}$

$\begin{array}{ll}\text { Figure 6.3 National Party 'Tax/Cut' Billboard } & 147\end{array}$

$\begin{array}{ll}\text { Figure 6.4 National 2005 Electorates Billboards } & 148\end{array}$

$\begin{array}{ll}\text { Figure 6.5 National 'Taxathon' Pamphlet } & 150\end{array}$

Figure 6.6 Screenshots of National 'Taxathon' Television Advertisement 151

Figure 6.7 Straight-Ticket Voting for the National Party, 1996-2005 154

Figure 6.8 National Valid Vote Share 1990-2005 155

Figure 7.1 New Zealand Political Spectrum with National Split into Separate Liberal

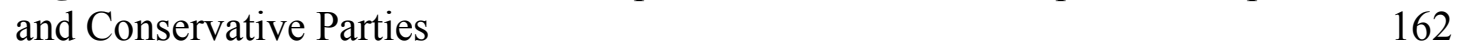




\section{Chapter One: Introduction}

The New Zealand National Party was formed in 1936 to bring the centre-Right into one political entity to fight the New Zealand Labour Party under first-past-the-post electoral rules. In that aim, it was successful. National has spent more time in government than any other political party in New Zealand. However, the environment in which National was shaped was dramatically changed with the introduction of a new electoral system mixed member proportional - at the 1996 election.

In the 1993, 1996, 1999 and 2002 elections National suffered a significant vote share decline from each previous result and ended up barely above twenty percent in 2002 . National undertook an internal review of its organisation in 2002-3 and found its organisation wanting. The Party centralised its organisational structure substantially in 2003. In 2005 National was able to raise its vote share dramatically - indeed it was the largest leap in support National had ever received.

The story of electoral reform in New Zealand is told elsewhere. ${ }^{1}$ Previously New Zealand used a simple plurality electoral formula in multiple single-member seats - or what is commonly referred to as first-past-the-post (FPP). FPP tends to create twoparty systems and one-party governments. After the electoral reform, New Zealand used mixed member proportional (MMP). MMP is a two-tiered electoral system: the upper tier is a nationwide tally of votes which proportionally determines the overall

\footnotetext{
${ }^{1}$ David Denemark, "Choosing MMP in New Zealand: Explaining the 1993 Electoral Reform," in Matthew Soberg Shugart and Martin P. Wattenberg (eds.), Mixed-Member Electoral Systems: The Best of Both Worlds?, (Oxford: Oxford University Press, 2001); Keith Jackson and Alan McRobie, New Zealand Adopts Proportional Representation: Accident? Design? Evolution? (Aldershot: Ashgate, 1998); Jack Nagel, "New Zealand: Reform by (Nearly) Immaculate Design," in Josep M. Colomer (ed.), Handbook of Electoral System Choice, (London: Palgrave-Macmillan, 2004).
} 
share of seats in the House of Representatives; while in the lower tier multiple districts elect a single representative using plurality rules. For parties which receive five percent of the upper tier vote (or the party vote as it is common known) or one electorate seat, list seats are allocated to ensure proportionality so that the upper tier over-rides that of the lower tier. Hence MMP produces an almost proportional result and is thus likely to produce a multi-party system and coalition governments.

National's decline and subsequent rise are, at least partially, organisational stories. Party organisation is both a mixture of formal rules and informal cultural norms. The formal rules are contained in a constitutional document, whereas the informal rules are expected actions and behaviours for various actors. The opportunities and challenges provided by an organisational structure act as a filter on party behaviour. An organisational rule or culture may create veto players who prevent certain behaviours and agenda setting players who push for certain behaviours and outcomes. A political party's organisational structure should be designed to help win elections; if not, they may face a vote share decline. Party behaviour sends signals to voters and influences their decision on who to elect.

The New Zealand National Party provides a useful case study of these phenomena. Under one electoral system, which required one form of campaigning and candidate, National succeeded. National brought that same organisational structure into a new environment, with a different form of campaigning and candidate required, which saw National falter. National changed its organisational structure by bringing power into the centre in two key areas. The new centralised organisation worked well in the new environment. National's experience affirms the theory that there is a relationship 
between the environment and political party organisation capability to attract votes. Some structures are more suited to some environments than others.

This thesis is primarily not the story of how the re-organisation was implemented or who implemented it or a list of rule changes, although there are stories to be told there. Rather, this thesis looks at why the changes were needed and what impact the changes had. To do so, this thesis looks at what impact party organisation has on party behaviour in two key areas - candidate selection and campaigning. These two areas are both key elements that parties play within a democracy and are two of the most important elements and clash points within political parties. Furthermore, they provide external evidence as to whether party behaviour changed. Candidate selection determines the public face of the party and is one of the most significant battlegrounds for control within a party. Campaigning needs to target certain voters depending on the electoral environment and different elements within a party may seek different groups of voters, hence who controls the campaign is internally important.

\section{Knowledge Gained}

Significant academic knowledge can be gained from researching the National Party. It is hard to discern the influence of one environmental factor across parties in multiple countries. No political party operates in two countries. Comparative studies of the impact of one institution on party organisation come up against other differences between countries and parties. However, the National Party provides a clear and unique opportunity to study the impact of the electoral system change on party organisation. The differences to New Zealand during this period are minimal when 
compared to the differences between the archetypical home of the two electoral systems - the United Kingdom (FPP) and Germany (MMP).

Furthermore, the fact that the effectiveness of political party organisation is environmentally-contingent brings into question the assumption that party organisations have evolved according to universal trends. The study of parties needs to move beyond that of labelling political parties as being 'elite', 'mass', 'catch-all' or 'cartel', and instead understand the individual complexity of each party and why parties take certain forms in certain environments.

The case study of the New Zealand National Party provides insights about political parties more generally. Pressure for electoral reform has grown in other modern democracies. Political parties which formed their organisation in one electoral environment may find themselves confronted by challenges in a new electoral environment which their organisation is ill-suited. What happened to National may give cause for despair, in that significant decline may occur as a result of electoral system change, or hope, as it is possible to change and revitalise organisational structure. Other parties may learn from what happened to National and be better prepared to face the challenges of electoral reform.

\section{Layout of Thesis}

This thesis is structured to seek out the insights from National's experience. First of all, a theoretical framework is built. Some previous work has been undertaken on the influence of the electoral system on political party organisation - most notably in candidate selection methods and campaigning - and these are expanded on. Specific 
organisational structures may be 'appropriate' for different environments and organisational ideals are looked at for three electoral systems - FPP, party-list proportional representation and their hybrid, MMP. It is argued that political parties operating in an MMP environment require a more centralised organisation than political parties operating in a FPP environment. The challenges to analysing whether centralisation is due to electoral reform are also identified.

Chapter Three analyses National's political, ideological and organisational history. The history demonstrates the advantages of a decentralised structure within an FPP environment. Decentralisation permitted potentially conflicting interests to remain within a single organisation. Furthermore, decentralisation allowed National's campaigning to focus on winning the plurality of votes in electorates. National became the 'natural party of government' in part due to its decentralised organisation.

The decline that National entered into from 1993 to 2002 is then explored in Chapter Four. The introduction of MMP raised a challenge for National - the need to campaign to maximise votes in a single nationwide electorate. National's organisation was unsuited to doing so and was the primary cause of National's decline - especially as other potential factors are ruled out. The Party elites understood that organisation was the primary cause of decline and tried to change it. The attempted centralisation of 1997 failed but hinted at many of the reforms undertaken in the 2003 centralisation, which was indeed a success as demonstrated by candidate selection and campaign structure. 
MMP requires a different form of candidate than FPP which needs to focus on the nationwide electorate. Decentralised candidate selection methods meant that the 1996, 1999 and 2002 candidate pools were unsatisfactory and hindered the Party from campaigning successfully under the new electoral rules. The 2003 review centralised candidate selection even though formally it became more decentralised. These changes are then analysed in National's candidate selection operation for the 2005 election. Ultimately institutional inertia prevented the complete centralisation of candidate selection and thus left 'unfinished business'.

One of the major problems of the old organisation was that National was not campaigning properly for a nationwide campaign as the new electoral system required. The decentralised organisation allowed electorates too much control to run their own campaign at the cost of a central campaign strategy. The changes to National resulted in greater central flexibility and control over the campaign. The 2005 election campaign is analysed to see how the centralisation enabled the party to run a better nationwide campaign. The new organisation enabled National to reverse the decline it had been in for the previous four elections.

Finally, the conclusion analyses whether the theorised relationship between electoral system and party organisation is correct. While National provides one single case study, it does point to a casual relationship which needs to be explored further through a large-scale comparative project. There is also speculation on long-term structural issues and challenges that National may need to deal with. 


\section{Chapter Two: The Impact of Electoral Reform on Party Organisation}

Two different areas of study within political science - electoral systems and political parties - overlap in a number of different ways. The study of both areas is well established, but the study of the area of overlap contains several holes. They are of course understandable - for an academic to study the overlap would require comprehensive understanding of two different areas which may not both be of interest to a researcher. Broadly, there are four main areas of research that overlap between electoral systems and political parties. The most obvious, and best researched, is the campaign period and elections - in which political parties operate within a set electoral system environment and compete for policy, office and/or votes. Secondly, the impact of the electoral system on the party system is also well documented and indeed has well established 'laws'. The next area of study is the impact political parties have on the electoral system; although studies are not common, the research on this subject is expanding. The final area of study is the impact electoral systems have on how political parties organise themselves. This area is most in need of more academic attention and is the focus of this thesis.

The experience of the New Zealand National Party provides a unique case study for the impact of electoral systems on party organisation. New Zealand changed its electoral system in a referendum in 1993, and the new system was first used in 1996. Previously, New Zealand used first-past-the-post (FPP), afterwards New Zealand used mixed member proportional (MMP). As MMP is a two-tiered system and a hybrid of different electoral systems - predominately party-list proportional representation 
(PLPR) but with some elements from FPP - it presents unique party organisation challenges and hence provides a perfect example of the impact of electoral systems.

Two areas highlight the key aspects of the impact of different electoral systems on party organisational rules. Candidate selection mechanisms strongly influence who becomes a legislator and hence shape the public face of the party. Campaign structure is the other key aspect as it impacts on how the party contests elections, what voters it targets and where it targets resources. While analysing party organisation could simply focus upon governance, these two roles are vital to parties and provide external clues as to whether a re-organisation is purely administrative or has significant impact upon party behaviour and hence the politics of the polity. There are challenges to analysing the impact electoral reform has had on party organisation (such as international trends in party organisation and oligarchic tendencies) as these may provide alternative explanations for centralisations within parties.

Richard Katz argued that, when considering party organisation ideals, the question to be asked is:

If rational candidates were designing a party with no aim in mind other than maximising their own chances of election and reelection, what would it be like? ${ }^{1}$

A similar approach will be taken here, but will also consider the party-as-a-whole. While political party goals often extend to being more than just seeking election and reelection, ideal party structures do exist as Weberian ideal types. However, what is ideal in one environment may not be in another.

\footnotetext{
${ }^{1}$ Richard S. Katz, A Theory of Parties and Electoral Systems (Baltimore and London: The Johns Hopkins University Press, 1980), 17.
} 


\section{The Impact of Electoral Systems on Party Organisation}

Different environments have different impacts upon political party organisation. Each polity has different laws and rules, peoples, political cultures and histories - all of these impact upon the citizenry and the political elites. Party organisation is not independent of these impacts, but is shaped by the legal framework, by the party leaders and members, and the voters whom they seek out. Hence environmental features are significant determinates of how a party organises itself.

In a 1981 study Robert Harmel found that a country's physical size, sectionalism, the strength of the legislature, federalism and decentralisation all have an impact upon the degree of centralisation within a political party; Harmel found no evidence that social heterogeneity or presidentialism affected party centralisation. ${ }^{2}$ A year later, Harmel and Kenneth Janda found that modernity, restrictions on suffrage, age of democracy, party competition and the electoral system all impact upon the degree of party complexity. ${ }^{3}$ However, neither of these works provides a suitable framework for the analysis of the impact of electoral reform within New Zealand on party organisation because they are too general and do not address the details of the formal and informal rules of political party organisation.

There are some other academic works dealing with the impact of the electoral system on party organisation. Japan's electoral reform affected the nature of factionalism and

\footnotetext{
${ }^{2}$ Robert Harmel, "Environment and Party Decentralization: A Cross-National Analysis," Comparative Political Studies 14, no. 1 (1981).

${ }^{3}$ Robert Harmel and Kenneth Janda, Parties and their Environments: Limits to Reform? (New York: Longman, 1982), 49.
} 
campaign practices within the Liberal Democratic Party. ${ }^{4}$ Ma and Choy looked at Hong Kong's electoral reform, from FPP to PLPR, and noted that "under [PL]PR the campaign did become more party-centred, more capital-intensive and media-intensive, with less emphasis on personalities, local issues and constituency services, and fewer negative campaigns." ${ }^{5}$ Katz dealt with the impact of ballot structure (categorical versus ordinal) and district magnitude on parties. ${ }^{6}$ Yet none of these works provides a suitable framework for analysing changes to party organisation in New Zealand due to the different nature of the electoral systems being dealt with. Instead, a different framework will be established, primarily focusing on candidate selection and campaigning.

Not all organisations are equally suited to mastering the challenges that environments throw at them. Some organisational structures are more suited to dealing with challenges created by some environments than others. MMP requires both a national candidate selection process and a national campaign for the party vote. Hence MMP is likely to need a more centralised party organisation than FPP.

\section{$\underline{\text { Candidate Selection }}$}

Michael Gallagher notes that the electoral system does not necessarily affect the degree of centralisation within the candidate selection process. Instead the "electoral system

\footnotetext{
${ }^{4}$ Ellis S. Krauss and Robert Pekkanen, "Explaining Party Adaptation to Electoral Reform: The Discreet Charm of the LDP?," Journal of Japan Studies 30, no. 1 (2004); Ray Christensen, "The Effect of Electoral Reforms on Campaign Practices in Japan: Putting New Wine into Old Bottles," Asian Survey 38 , no. 10 (1998).

${ }^{5}$ Ngok Ma and Chi-keung Choy, "The Impact of Electoral Rule Change on Party Campaign Strategy: Hong Kong as a Case Study," Party Politics 9, no. 3 (2003).

${ }^{6}$ Katz, A Theory of Parties and Electoral Systems.
} 
strongly affects the mechanics of the selection process in every country.", As Hazan and Voerman note:

Electoral systems at the national level and candidate selection methods at the party level are connected, maybe not causally but they do influence each other. More precisely, the electoral system constrains and conditions the parties' menu of choices concerning candidate selection. ${ }^{8}$

While the relationship is complicated, electoral systems do influence candidate selection processes to some degree.

Different electoral systems require different numbers of candidates per electoral district and the electoral units are on different scales. These two factors are independent of each other in different systems, for instance a presidential election requires one candidate for an entire country; whereas bloc voting, single transferable voting and single non-transferable voting all require multiple candidates in small geographic districts. Further, electoral systems in which there is only one candidate per district allow for a simpler selection process than one in which there are many candidates per district.

Under a FPP electoral system selecting a candidate can be a straight-forward affair. Each electorate only requires one candidate to be selected. However, the selectorate may be composed of in many ways. Some parties may place the selection decision in

\footnotetext{
${ }^{7}$ Emphasis in original. Michael Gallagher, "Conclusion," in Michael Gallagher and Michael Marsh (eds.), Candidate Selection in Comparative Perspective: The Secret Garden of Politics, (London: Sage, 1988), 260.

${ }^{8}$ Reuven Y. Hazan and Gerrit Voerman, "Electoral Systems and Candidate Selection," Acta Politica 41, no. 2 (2006).
} 
the hands of the local party members, other parties may allow the head office to decide and some parties may place the decision in between the two extremes. The process is likely to be relatively simple as just one candidate is selected. As the candidate only needs to win a plurality in a small geographic electorate, there is little need for considering diversity. Hence, a decentralised selectorate will be able to select an 'appropriate' candidate.

PLPR selection methods tend to be more complex. In order to select multiple candidates for a party list an internal electoral system (a 'selectoral system') needs to be developed. Outright voting may not be appropriate as "[PL]PR systems carry with them a need for a balanced ticket with, perhaps, a greater emphasis on aspirants' objective personal characteristics such as gender, age and group affiliation."9 Hence, the selectorate may discuss and appoint rather than vote and elect. Furthermore, in list systems a high ranking is seen as a positive and infighting is likely to be more substantial than in 'in/out' systems. As PLPR tends to have large district magnitudes (in some instances, nationwide), representation on the selectorate may need to be formalised in order to keep the party balanced.

Under MMP complexity rises when compared to both FPP and PLPR due to the twotiered nature of the system. FPP enabled all selections to be done at a local level if the party so decided. PLPR requires a nationwide or regional list selection and hence a nationwide or regional selectorate. However, MMP within New Zealand requires one nationwide list which needs to be determined at a nationwide level and an electorate selection process.

\footnotetext{
${ }^{9}$ Gallagher, "Conclusion," 260.
} 
Different district magnitudes require different forms of candidates. Single-member constituency candidates often reflect the prevailing social characteristic and identity of the region and selectorate - hence white males tend to dominate. ${ }^{10}$ However, a list of candidates needs to reflect all social characteristics and identities to some degree. Linking the list and electorate candidate through dual candidacy may make the candidate pool inappropriate for one tier of the electoral system and negatively affect the party's ability to win either electorate or party votes.

Yet linking the candidate pools through dual candidacy may have a positive impact on campaigning. If a party uses a system in which there is no direct relationship between the two tiers then the different pools of candidates are likely to campaign independently for separate votes. Electorate-only candidates may run a personalistic campaign, largely ignoring the party vote element, whereas list-only candidates may run a party vote-only campaign. The most beneficial campaign for both the party and the electorate candidate is to run a 'two-ticks' campaign if they are complementary in what voters they seek.

Ultimately it is the party vote that matters most under MMP for maximising parliamentary representation. Hence, it is the nationwide candidate pool that is most important, not the local candidate. Parties are what matter, not individual candidates.

\footnotetext{
${ }^{10}$ Males have still tended to dominate as candidates even though women make up fifty percent of the population. See: Richard E. Matland, "Enhancing Women's Political Participation: Legislative Recruitment and Electoral Systems," in Julie Ballington and Azza Karam (eds.), Women in Parliament: Beyond Numbers, (Stockholm: International Institute for Democracy and Electoral Assistance, 2005), 94-97; Nadezhda Shvedova, "Obstacles to Women's Participation in Parliament," in Julie Ballington and Azza Karam (eds.), Women in Parliament: Beyond Numbers, (Stockholm: International Institute for Democracy and Electoral Assistance, 2005), 35-38.
} 
Voters are more likely to determine their party vote on the overall composition of the list, rather than who their local candidate is. Parties should place more control, over both tiers of candidate selection, with a central selectorate rather than depending on the choices of local selectorates. The campaign benefits of linking the two candidate pools out-weigh those of separating the two pools. While identity electorate candidates may be less suited to winning electorate votes, overall they will contribute more to the nationwide vote tally through their nationwide appeal.

In the lead up to the change to MMP parties will need to adopt a new list candidate selection method. Introducing candidate selection rules for a new electoral system "is not only a major organizational undertaking for the political parties, it undoubtedly involves political consequences". ${ }^{11}$ Parties need to create a new method of selecting candidates which may lead to the party having to address divisions within the party which were previously settled (or at least ignored). The easiest way for parties to address the changes in moving from FPP to MMP is to introduce a list selection process and leave the electorate selection process alone. Each pool would be separate to ensure that they are appropriate for the vote they are trying to gain. In a decentralised party it would be expected that the list selectorate would have strong regional representation. However, having significant regional representation may lead to infighting and no consideration of diversity on the list.

The ideal-type candidate selection for MMP and what a party finds easiest to put in place are likely to be at a disjunction. An MMP candidate selection method should provide parties with candidates that appeal to voters across the nation through a

\footnotetext{
${ }^{11}$ Hazan and Voerman, "Electoral Systems and Candidate Selection."
} 
centralised selection process. However, placing a centralised structure to ensure nationwide appeal is going to be hard for parties which have previously been operating in a decentralising environment. If a party is able to do so then their candidate pool will help attract voters; if not, it may contribute to a vote share decline.

\section{Campaign Structure}

Different electoral systems require different forms of campaigns and these different campaigns then entail different structures for party campaigns. FPP largely requires a decentralised campaign, whereas PLPR requires a more centralised campaign. With the change to MMP, a hybrid system, two levels of campaign emerge but ultimately MMP is more in tune with PLPR than FPP as it requires a party vote campaign first and foremost.

Under FPP, the nationwide campaign is not necessarily significant. While there is centralising pressure for parties to act cohesively at the parliamentary and policy levels, the pressure on campaigning is to decentralise the party. A FPP campaign requires parties to focus upon the "seats deemed most marginal, thereby rendering those few constituencies a strategic fulcrum and electoral centrepoint while relegating all safe seats to electoral obscurity." 12 The campaign would be best suited to focus on the issues and concerns of marginal electorate swing voters and not those of all electors. Pork-barrel politicking is likely to occur as parties try to win votes in a small number of

\footnotetext{
${ }^{12}$ David Denemark, "Thinking Ahead to Mixed-Member Proportional: Party Strategies and Election Campaigning under New Zealand's New Electoral Law," Party Politics 2, no. 3 (1996).
} 
small geographic districts. ${ }^{13}$ With the median swing voter so important, parties compete for the centre-ground in order to win elections. ${ }^{14}$

In order to campaign under FPP a party structure should be set up to focus resources on a few small geographical areas. Decisions on message targeting and campaign literature may be left to an extent to each constituency to ensure that resources are properly utilised to secure pluralities where possible. The geographic lines which dictate whether a voter matters or not create the lines as to where party resources are to be focused. Resources should be redistributed from 'safe' to 'marginal' electorates. Hence a degree of campaign decentralisation is to be expected within a FPP environment.

PLPR, in contrast, gives equal weighting to all voters. Parties need to be able to maximise their vote share throughout the country. There are fewer wasted votes. A vote in a marginal area is worth just as much as one in a safe area or an opposition stronghold. The focus on the campaign is nationwide. Pork-barrel politics is likely to be very low. ${ }^{15}$ Parties do not face electoral pressure to move towards the centreground, but rather to be ideologically distinct. ${ }^{16}$ Campaigning through television becomes more effective. Under PLPR, geographical targeting similar to - but also different from - FPP is important as voters of similar socio-economic groupings (and thus political groupings) tend to live in close proximity (in the same suburbs, cities and so forth). These are likely to be groups of core supporters which PLPR parties target

\footnotetext{
13 Thomas D. Lancaster, "Electoral Structures and Pork Barrel Politics," International Political Science Review/Revue Internationale de Science Politique 7, no. 1 (1986).

${ }^{14}$ Anthony Downs, An Economic Theory of Democracy (Boston: Addison-Wesley, 1985 [1957]), $117-$ 118.

${ }^{15}$ Lancaster, "Electoral Structures and Pork Barrel Politics."

${ }^{16}$ Downs, An Economic Theory of Democracy, 126-127.
} 
for 'get-out-the-vote' campaigns. Parties will divert resources from marginal areas to focus on these groups. ${ }^{17}$

Nationwide campaigning lends itself to a different form of party organisation. Central control becomes more important. The leader becomes more central to the campaign; this does not imply presidentialisation of the leader but rather that the leader "campaigns on behalf of the party and is therefore associated with its standpoints and ideology." 18 As there are no clear boundaries between areas and as there may be no candidate with strong links to certain communities, a strong central authority is needed to ensure that all areas are sufficiently covered. The central authority is the only internal organisation in a position to use nationwide television. ${ }^{19}$ Candidates can only benefit from the nationwide vote increasing, and are thus likely to accept central campaign control. ${ }^{20}$ Hence, a party operating in a PLPR electoral system is likely to have centralised campaign control.

The two-tiered MMP electoral system produces a two-tiered electoral campaign. On the lower tier, candidates fight in small units for a simple plurality of the electorate vote. Yet, in the upper tier, parties fight nationwide for as many party votes as they can muster. The nature and focus of the campaigns will differ, as Katz theorises:

Parties competing in small districts will tend to be personalistically oriented or patronage oriented, whereas

\footnotetext{
${ }^{17}$ Denemark, "Thinking Ahead to Mixed-Member Proportional."

${ }^{18}$ David M. Farrell, "Campaign Strategies and Tactics," in Lawrence LeDuc, Richard G. Niemi, and Pippa Norris (eds.), Comparing Democracies: Elections and Voting in Global Perspective, (Thousand Oaks: Sage, 1996), 165.

${ }^{19}$ Farrell, "Campaign Strategies and Tactics," 173.

${ }^{20} \mathrm{Katz}$, A Theory of Parties and Electoral Systems, 32.
} 
parties competing in larger districts will tend to be issue oriented. $^{21}$

In this view, electorate campaigns will remain personalistic, whereas the nationwide campaign will focus on issues and leaders. There is an incentive for electorate candidates to cultivate a personal vote at the electorate level. ${ }^{22}$ The campaign becomes more complex. Ultimately, it is the party vote aspect which determines the overall share of seats within the legislature. Hence the nationwide aspects of the PLPR campaign should outweigh the constituency level campaigns of FPP. Yet the electorate candidate may not agree.

Mixed electoral systems may produce complex, and sometimes contradictory, campaign structures in which there is intra-party conflict for control of resources and messages. As Katz notes:

To the extent that intraparty competition determines a candidate's electoral fortunes, candidates will tend to maintain separate campaign organizations. ${ }^{23}$

While MMP does not have direct intra-party competition (unlike the single-transferable vote which Katz dealt with), it is implicit due to the two-tiered nature of the electoral system. Katz's hypothesis can be modified for mixed electoral rules: to the extent that constituency candidates can secure their own election in their constituencies, candidates will focus more on the constituency vote and hence have separate campaign organisations. The electorates may use their resources to fight for a plurality of the electorate vote through personalistic campaigns undermining the party's party vote

\footnotetext{
${ }^{21}$ Katz, A Theory of Parties and Electoral Systems, 33.

${ }^{22}$ John M. Carey and Matthew Soberg Shugart, "Incentives to Cultivate a Personal Vote: A Rank Ordering of Electoral Formulas," Electoral Studies 14, no. 4 (1995).

${ }^{23}$ Katz, A Theory of Parties and Electoral Systems, 34.
} 
campaign. Consequently, the nationwide campaign may find itself battling against forces within its own party.

However, party campaign organisational structure under mixed electoral laws should be nationwide. While there will be pressure from constituency candidates to have their own campaign organisation, ultimately they are not working towards the good of the party-as-a-whole. The main aim of the party is to maximise the party vote in order to maximise the number of legislators. This may lead to the need for a very strong central campaign organisation which cannot only provide a nationwide focus but can also ensure that constituency candidates run a party vote campaign and place the needs of the nationwide party above and beyond their own election.

Paradoxically, while mixed electoral systems are viewed as being in between the 'extremes' of FPP and PLPR, ${ }^{24}$ they create pressure for party organisation to be at the extreme end of centralisation. The countervailing tensions to decentralise (from the electorate candidates) and to centralise (from the view of the party-as-a-whole) need to be brought under control. Only a strongly centralised campaign organisation can ensure the entire party works as a whole towards one goal of maximising the number of legislators through maximising the party vote. Indeed, parties may feel that 'spill-over' or 'contamination' is enough to ensure that constituency candidates are elected.

As with candidate selection, the introduction of a strong central agency to run a nationwide campaign is likely to face difficulties. The organisation structure of FPP is

\footnotetext{
${ }^{24}$ Matthew Soberg Shugart, "'Extreme" Electoral Systems and the Appeal of the Mixed-Member Alternative," in Matthew Soberg Shugart and Martin P. Wattenberg (eds.), Mixed-Member Electoral Systems: The Best of Both Worlds?, (Oxford: Oxford University Press, 2001).
} 
likely to have created institutional inertia against moving campaign control towards the centre. Again the structure a party finds easiest to implement and the MMP ideal type are likely to be at a disjunction potentially leading to poor party signals to voters and thus failing to attract votes.

Under MMP there are stronger incentives for both candidate selection and campaign organisation to be centralised than under FPP. With these two elements needing a stronger central authority, the governance structure of the party needs to give significant power to the central. Thus it is likely that the entire party organisation will become centralised rather than leaving some party functions decentralised. However institutional inertia will need to be overcome in order to enact the necessary changes.

\section{Challenges for Analysis}

There are several challenges in determining whether centralisation after electoral reform is due to the intricate workings of the new system or is a part of a different trend. There are a number of trends which result in the centralisation of a political party. The wider trends each have their own impetus for reform as well as other factors that should be present. However, if none of these factors are present then the centralisation can be ascribed to the change to MMP rather than electoral reform being used as an excuse by party elite reformers. Ultimately there is a need for multiple case studies in order to control other variables. 


\section{Centralisation as a Response to Decline}

Any party which undergoes significant vote share decline is likely to engage in selfreflection. There are many factors that lead to party decline - reduced trust, leadership crisis, poor policy, social and economic change, the rise of other competitive parties and so forth. While these factors may have led to the decline "parties in defeat tend to blame weak organization rather than weakness in policy", ${ }^{25}$ thus centralising party organisation when it was not the cause of the vote share decline. There have been numerous recent examples within Western Europe in which political parties have faced a decline or defeat and consequently had to adapt in order to survive. ${ }^{26}$

Parties' responses to decline include centralising party organisation, opening up leadership and candidate selection to the wider party membership, and decreasing the separation between the party and the leadership. ${ }^{27}$ Failure to adapt has been common and has led to substantial problems and the rise of alternative political parties. ${ }^{28}$ Parties have had to adapt to changing environments and have tended to do so by increasing leadership flexibility instead of reverting back to the ideological roots of the party.

It can be difficult to determine whether a party is reforming itself due to decline or due to electoral reform, as post-electoral reform parties that have inappropriate structures are likely to decline in the new electoral environment. Hence, the key to analysing whether centralisation is due to the impact of the electoral system on party organisation

\footnotetext{
${ }^{25}$ R. S. Milne, Political Parties in New Zealand (Oxford: Clarendon Press, 1966), 170.

${ }^{26}$ Peter Mair, Wolfgang C. Müller, and Fritz Plasser (eds.), Political Parties and Electoral Change: Party Responses to Electoral Markets (London: Sage Publications, 2004).

${ }^{27}$ Peter Mair, Wolfgang C. Müller, and Fritz Plasser, "Conclusion: Political Parties in Changing Electoral Markets," in Peter Mair, Wolfgang C. Müller, and Fritz Plasser (eds.), Political Parties in Changing Electoral Markets, (London: Sage, 2004), 265.

${ }^{28}$ Mair, Müller, and Plasser, "Conclusion," 268-272.
} 
is to analyse what caused the party to decline. If there is sufficient evidence to suggest that other factors apart from electoral reform are responsible for the decline then it is possible that the organisation was 'appropriate' for the new environment. Further evidence can be found after the centralisation - if other factors are responsible for the decline then a re-organisation may be unable to deal with them and hence the party will continue to suffer poor results. However, if there is no evidence that other factors are responsible for decline, and after the re-organisation the party recovers votes, then it is likely that the party organisation needed to be changed due to the electoral reform.

\section{Centralisation as a Response to Internal Instability}

Internally, political parties are not unified - there are many internal divisions. Occasionally, the balance of power changes within parties, leading to the new controllers to attempt to change the organisational structure to benefit themselves. ${ }^{29}$ Parties in a turbulent electoral environment may have significant internal politicking and thus some elites may try to take over the party. A stable electoral arena means "we can expect greater cohesion and stability in the parties' dominant coalitions", whereas in a turbulent arena "the dominant coalition is likely to have... serious internal tensions". ${ }^{30}$ Changing an electoral system is likely to cause voter fluidity and thus internal tensions may rise within the existing parties ultimately leading some elites to attempt to takeover the party.

\footnotetext{
${ }^{29}$ Robert Harmel, Uk Heo, Alexander C. Tan, and Kenneth Janda, "Performance, Leadership, Factions and Party Change: An Empirical Analysis," West European Politics 18, no. 1 (1995).

30 Angelo Panebianco, Political Parties: Organization \& Power, trans. Marc Silver (Cambridge: Cambridge University Press, 1988), 208.
} 
In this view, a party centralisation process is the victory from a battle for some elites to gain greater control over the party. It can be predicted that those elites would seek out reforms which would strengthen their control over as many aspects of the party as possible. Furthermore, there would be attempts to institutionalise their control by limiting the ability of other elites in moving into the new central authority. Hence, there would be expectations for the post-centralised party organisation to have no regional representation on the central executive or selectorate and to have an internal electoral system for the executive which strongly favours incumbents.

Several factors must be present for this theory to be accepted. First of all, there must be a clear group of elites pushing these reforms. Secondly, there must be clear evidence of significant internal disputes between different elite groups. The dispute should not just be evident before the attempted centralisation, but would be significant in the party conference in voting on organisational reform. Furthermore, the rule changes should strongly benefit the central elites and institutionalise their position. Without these factors it is unlikely that the reform was solely part of internal instability and infighting for control.

\section{Centralisation as a Movement towards the Cartel Model}

Party organisation has seemingly gone through various different models. Parties were first formed as 'elite' parties within the legislature environment. 'Mass' parties arose in response, with large membership bases and organisational structures. As parties lost membership and voter loyalty, they took on the 'catch-all' model. More recently parties have taken on another form - the 'cartel' model. Katz and Mair note that in the cartel party model: 
[Members] affiliate directly with the central party, obviating the need for local organizations, and hence also for local organizers. Indeed, it becomes possible to imagine a party that manages all of its business from a single central headquarters. ${ }^{31}$

Any party following the cartel model is significantly centralised and professionalised.

The cartel model also requires a centralised structure. Other features of the cartel model would likely be pushed as well, and the absence of these would indicate that perhaps cartelisation is not the primary cause of the re-organisation. Cartel parties tend to also blur the lines between supporter and member - often supporters are allowed to participate in party activities. Delegate rules change from the delegate to the trustee model to break the power of regional or sector elites. Moreover, cartel parties often appropriate state resources, working in collusion with other parties to do so. ${ }^{32}$ Again, the absence of these other rule changes would indicate that centralisation is not due to cartelisation.

These three alternative explanations to centralisation all require certain events, structures and rule changes. While all three are generalised, it would be expected that a party undergoing centralisation as a result of any of these three developments would exhibit at least signs of attempted further change along specific lines. Hence to establish that a party's re-organisation is a result of electoral reform there needs to be significant evidence that electoral reform is not simply being used as an excuse by the organisation reformers.

\footnotetext{
${ }^{31}$ Richard S. Katz and Peter Mair, "Changing Models of Party Organization and Party Democracy: The Emergence of the Cartel Party," Party Politics 1, no. 1 (1995).

${ }^{32}$ Katz and Mair, "Changing Models of Party Organization and Party Democracy."
} 


\section{Parties Undergoing Electoral Reform}

Political parties after electoral reform can expect to undergo some significant changes internally. The ideal typology is unlikely to be met in any situation as there are numerous other factors involved. Political party organisation is 'conservative' - it does not change without reason and motivation. ${ }^{33}$ Parties are likely to suffer from a 'FPP hangover' and attempt to retain their FPP organisational structure in the new electoral environment. Institutional inertia may freeze organisation as some elites seek to retain their power. In theory, a party which is unlike its ideal type should find significant difficulty in selecting appropriate candidates and running an appropriate campaign. Hence, under a new electoral system, ceteris paribus, parties which react quickly in adopting a new model (or even had it in place already) are likely to fare better than those who retain most, if not all, of their previous organisational structure.

Thus, hypotheses can be proposed for political parties making the transition from FPP to MMP, as happened in New Zealand:

Hypothesis 1: In competitive environments, political parties require an organisation which is suited to the environment in which they operate in.

Hypothesis 2: MMP requires a more centralised organisation than FPP.

Hypothesis 2.1: A Shift from FPP to MMP is likely to produce a centralisation of candidate selection and campaigning.

\footnotetext{
${ }^{33}$ Robert Harmel and Kenneth Janda, "An Integrated Theory of Party Goals and Party Change," Journal of Theoretical Politics 6, no. 3 (1994).
} 
The National Party provides an excellent case study for testing these hypotheses as it is a party dedicated to winning elections above all else and its organisational structure was set up to do so under FPP. Hence, pressure to reform organisation to win elections is likely to be stronger in National than in Labour, which has been more accepting of electoral defeat and being in opposition.

National faced new challenges in the MMP environment. For the first time National had to create a nationwide list which appealed throughout the country, rather than to a small electorate. National also had to figure out how to maximise the party vote through the country, rather than focusing on receiving the plurality in small electorates. These challenges required new activities and new organisational capabilities, which the decentralised organisation struggled to meet. 


\section{Chapter Three: The New Zealand National Party}

The New Zealand National Party was formed in 1936 and soon became the most successful political party in New Zealand. National has been able to form government more often than any other party and dominated the government benches from 1949 to 1984. The Party has always had two distinct ideological branches running through both the caucus and the organisation. Consequently, the Party organisation has had to be flexible enough to sustain two different strands of thought in one political entity while still realising the goal of winning office. National achieved this by decentralising its organisation to five divisions and to the electorates. The distinct environment in which National formed allowed it to become a success.

\section{History}

From the Party's formation in 1936 until the change to the mixed member proportional (MMP) electoral system, National had an average vote share of 44 percent. National won twelve of the nineteen first-past-the-post (FPP) elections it contested. However, according to proportional tenure criteria National 'should' have won only 44 percent (or 8.4 elections) of the FPP elections it contested. ${ }^{1}$ While National has been highly successful in terms of winning office and votes, it has been unable to create policy in line with its ideological backgrounds, having to be largely content with managing Labour's welfare state.

\footnotetext{
${ }^{1}$ For proportional tenure, see: Peter J. Taylor, "The Case for Proportional Tenure: A Defense of the British Electoral System," in Arend Lijphart and Bernard Grofman (eds.), Choosing An Electoral System: Issues and Alternatives, (New York: Praeger, 1984); Peter J. Taylor and Arend Lijphart, "Proportional Tenure vs Proportional Representation: Introducing a New Debate," European Journal of Political Research 13, no. 4 (1985).
} 


\section{Formation}

The New Zealand National Party was formed at a conference in Wellington over 13/14 May 1936. However, calls for the National Party to form predate the conference. Previous attempts to establish one political entity on the Right failed on several occasions. The success in keeping one party has been rewarded substantially at the ballot box. The formation period highlights many of the problems constantly faced throughout the history of the National Party.

The Liberal and Reform parties, formed by urban liberals and rural conservatives respectively, dominated New Zealand politics in the early $20^{\text {th }}$ century. The New Zealand Labour Party was established in 1916 and took eight seats in the 1919 election. Labour won seventeen seats in 1922, and interest rose in fusing Liberal and Reform together. Reform Leader, and Prime Minister, Bill Massey argued:

[T] he results of the election show the necessity for a reconstruction of parties. The three party system cannot possibly be satisfactory in any case, and it is simply folly for the Liberals and Reformers to go fighting each other when so far as policy is concerned there is little or nothing between them. ${ }^{2}$

Massey understood Duverger's Law before Maurice Duverger. A conference was held in 1925, but failed to merge the parties as new Reform Leader Gordon Coates believed the Liberals would soon fade away altogether. ${ }^{3}$

\footnotetext{
${ }^{2}$ Quoted in: Alan Robinson, "The Rise of the New Zealand National Party, 1936-1949" (MA, University of New Zealand (Victoria), 1957), 4.

${ }^{3}$ Barry Gustafson, The First 50 Years: A History of the New Zealand National Party (Auckland: Reed Methuen, 1986), 2-3.
} 
United (a new name for the Liberals) and Reform competed together as a coalition in the 1931 elections, and won. For the 1935 election United and Reform decided to cofight Labour as the National Political Federation. With the two parties co-fighting another election together, United members called for a permanent fusing of the parties. However, Reformers rejected the calls. At the 1935 election Labour defeated the Federation - who not only had to deal with the Great Depression and an electorate tired of their old candidates, but also with Labour's far superior organisation. ${ }^{4}$ The Federation was left with just 17 Members of Parliament (MPs).

In 1936 a seriously demoralised and divided grouping merged. The Dominion Executive of the National Political Federation recommended fusing the parties along with other anti-Labour forces such as the Democratic Party. Subcommittees were formed to draft a constitution and the conference was called for 13 and 14 May 1936 in Wellington. After a protracted debate over the new party's name, 'The New Zealand National Party' was formally adopted, and Reform and United disbanded. The doctrines of the party were discussed with eight objectives adopted, only three of them on policy issues - two conservative and one liberal. ${ }^{5}$ From the start, National tried to downplay the internal ideological divide within the organisation.

Soon the Party began to get active. Large recruitment drives throughout the country saw membership increase rapidly. For instance, the Auckland Division's membership went from 4,388 in January 1938 to 20,958 by mid-August. ${ }^{6}$ The 1938 election was fought on an anti-Labour platform and National gained six new MPs. The 1943

\footnotetext{
${ }^{4}$ Gustafson, The First 50 Years, 4, 6-7.

${ }^{5}$ For the objectives, see: Gustafson, The First 50 Years, 9-10.

${ }^{6}$ Gustafson, The First 50 Years, 25.
} 
election saw National gain a further eight seats, but lost the election due to the soldiers' vote favouring Labour. ${ }^{7}$ The 1946 election was again almost National's first victory; however the four Māori seats, ${ }^{8}$ and thus the election, went to Labour.

\section{The Natural Party of Government, 1949-1984}

National's first victory was not until 1949. New National Party Prime Minister Sidney Holland dismantled many of the remaining rationing and controls from World War II, only to reinstate some of them due to high inflation and two balance of payments crises in 1952 and 1954. The National Government took a tough stance against the waterfront workers in the largest industrial dispute in New Zealand. New Zealand entered into a formal military alliance with the United States indicating a swing away from the traditional reliance on Britain. Nearing the 1957 election the country's economy deteriorated and Holland was unwell, having to be replaced as Prime Minister by Keith Holyoake. The 1957 election was won by Labour by a margin of just two seats.

National aggressively attacked the Second Labour Government, successfully labelling the 1958 budget as the 'Black Budget' and undermining the public's faith in Labour. The 1960 election resulted in a 12 seat victory for National. Compulsory unionism was abolished, compulsory military training reintroduced, troops were sent to Vietnam and the policy of assimilating Māori into Pākehā society began. The government rode the wave of economic prosperity. In 1972, Holyoake stood down as Prime Minister for John Marshall. However, the electorate felt that it was 'time for a change' and elected Labour, led by the charismatic Norman Kirk.

\footnotetext{
${ }^{7}$ Gustafson, The First 50 Years, 50.

${ }^{8}$ The spelling "Māori" will be used, except in quotations.
} 
Labour suffered from two events outside of its control - the oil shock in 1973 which sent the world's economy into crisis, and the untimely death of Norman Kirk in 1974. National, now led by Robert Muldoon, successfully won the 1975 election against Bill Rowling. Muldoon was naturally a populist and held onto the security blanket that was the welfare system. With economic problems developing, Muldoon implemented significant controls on the New Zealand economy such as heavy borrowing and freezing wages and prices. National only survived the 1978 and 1981 elections due to the distortions of FPP - in both elections Labour won more votes although National won more seats. Internal discontent with Muldoon became apparent, with a 'Colonel's Coup' being launched in 1980 against Muldoon, but falling over at the last moment.

While National was highly successful in winning office, it came at the expense of implementing policy in line with National's intellectual tradition. National had to be content with largely managing Labour's welfare system, rather than dismantling it, ${ }^{9}$ and the level of inter-party policy consensus was extremely high. ${ }^{10}$ Not only were voters not attracted to proposals to radically reform the New Zealand economy, National also struggled to formulate policy which pleased all of its interests and factions, and thus became content with accepting the status quo rather than risk infighting and desertions. ${ }^{11}$ The Party clearly favoured office, votes and internal stability over policy innovation and implementation.

\footnotetext{
${ }^{9}$ Milne, Political Parties in New Zealand, 285; Anthony Wood, "National," in Raymond Miller (ed.), New Zealand Government and Politics, (Melbourne: Oxford University Press, 2003), 251; Richard Mulgan, Politics in New Zealand, third (updated by Peter Aimer) ed. (Auckland: Auckland University Press, 2004), 239.

${ }^{10}$ Milne, Political Parties in New Zealand, 275.

${ }^{11}$ Milne, Political Parties in New Zealand, 276.
} 


\section{Liberalisation and Realignment, 1984-1993}

The bipartisan Keynesian policy consensus was destroyed, not by National, but by Labour. In 1984, the Fourth Labour Government was elected and embarked upon a radical liberalisation of the economy. ${ }^{12}$ National became split between those tied to the post-war consensus (especially the farming community) who wanted to use the discontent that 'Rogernomics' was creating in order to win office, and those who wished to re-assert National as the party of the Right and take a more pronounced neoliberal line. ${ }^{13}$ Furthermore, social/moral issues were becoming more prominent within New Zealand. During the Fourth Labour Government the conservative and liberal factions within National became clearer and were "increasingly visible and solid, and their existence was apparent in both the party organisation and caucus." 14

The 1980s was a period of soul-searching for National. Labour was seemingly more aligned with business than was National. But some of the Labour policies were causing great harm to the other key support group for National - farmers. The quick leadership transitions from Robert Muldoon to Jim McLay and then to Jim Bolger were part of the infighting within the caucus for control over the direction of the National Party. ${ }^{15}$ The 1987 and 1990 elections, which National expected to win almost as of right, ${ }^{16}$ were

\footnotetext{
${ }^{12}$ For an understanding as to why, and how, Labour undertook a radical liberalisation project, see: Roger Douglas, "How We Did It," in Margaret Clark (ed.), For the Record: Lange and the Fourth Labour Government, (Wellington: Dunmore Press, 2005).

${ }_{13}$ Bryce Edwards, "Political Parties in New Zealand: A Study of Ideological and Organisational Transformation" (PhD, University of Canterbury, 2003), 134-135.

${ }^{14}$ Edwards, "Political Parties in New Zealand", 135.

${ }^{15}$ Ruth Richardson, Making a Difference (Christchurch: Shoal Bay Press, 1995), 39; Edwards, "Political Parties in New Zealand", 134-135.

${ }^{16}$ See: Richardson, Making a Difference, 38.
} 
fought with a "deliberately ambiguous [platform] in order to satisfy the left and right internal camps." 17

At the 1990 election National won over two-thirds of the seats. While Prime Minister Jim Bolger was moderate and conservative, Minister of Finance Ruth Richardson implemented significant neo-liberal reforms. The large, unwieldy caucus began to split. Gilbert Myles and Hamish MacIntyre left to form the (conservative) Liberal Party. Winston Peters, Minister of Māori Affairs, was sacked from Cabinet, eventually forming his own political party after the National Executive refused to allow Peters to seek re-nomination for National. ${ }^{18}$ Cam Campion also left National after he was not reselected in Wanganui.

In the 1993 election National came within a whisker of electoral defeat and recorded its lowest ever vote share, although not substantially lower than the 1984 election. Labour declined further, sitting just 0.4 percent lower than National in the overall vote. Public distrust for the main parties was high. ${ }^{19}$ Bolger removed Ruth Richardson from the Finance portfolio and attempted to stop the vote share decline. National reverted to being a conservative/status quo party, reversing some previous policy decisions although still implementing tax cuts. ${ }^{20}$

\footnotetext{
${ }^{17}$ Edwards, "Political Parties in New Zealand", 136..

18 Raymond Miller, "New Zealand First," in Raymond Miller (ed.), New Zealand Government and Politics, (Melbourne: Oxford University Press, 2003), 261-262; Martin Hames, Winston First: The Unauthorised Account of Winston Peters' Career (Auckland: Random House, 1995), 182-185.

19 Tim Bale and Nigel S. Roberts, "Plus ça change...? Anti-Party Sentiment and Electoral System Change: A New Zealand Case Study," Commonwealth and Comparative Politics 40, no. 2 (2002).

${ }^{20}$ Edwards, "Political Parties in New Zealand", 175; Wood, "National," 253.
} 
Figure 3.1 National Party Vote Share under FPP, 1938-1993 ${ }^{21}$

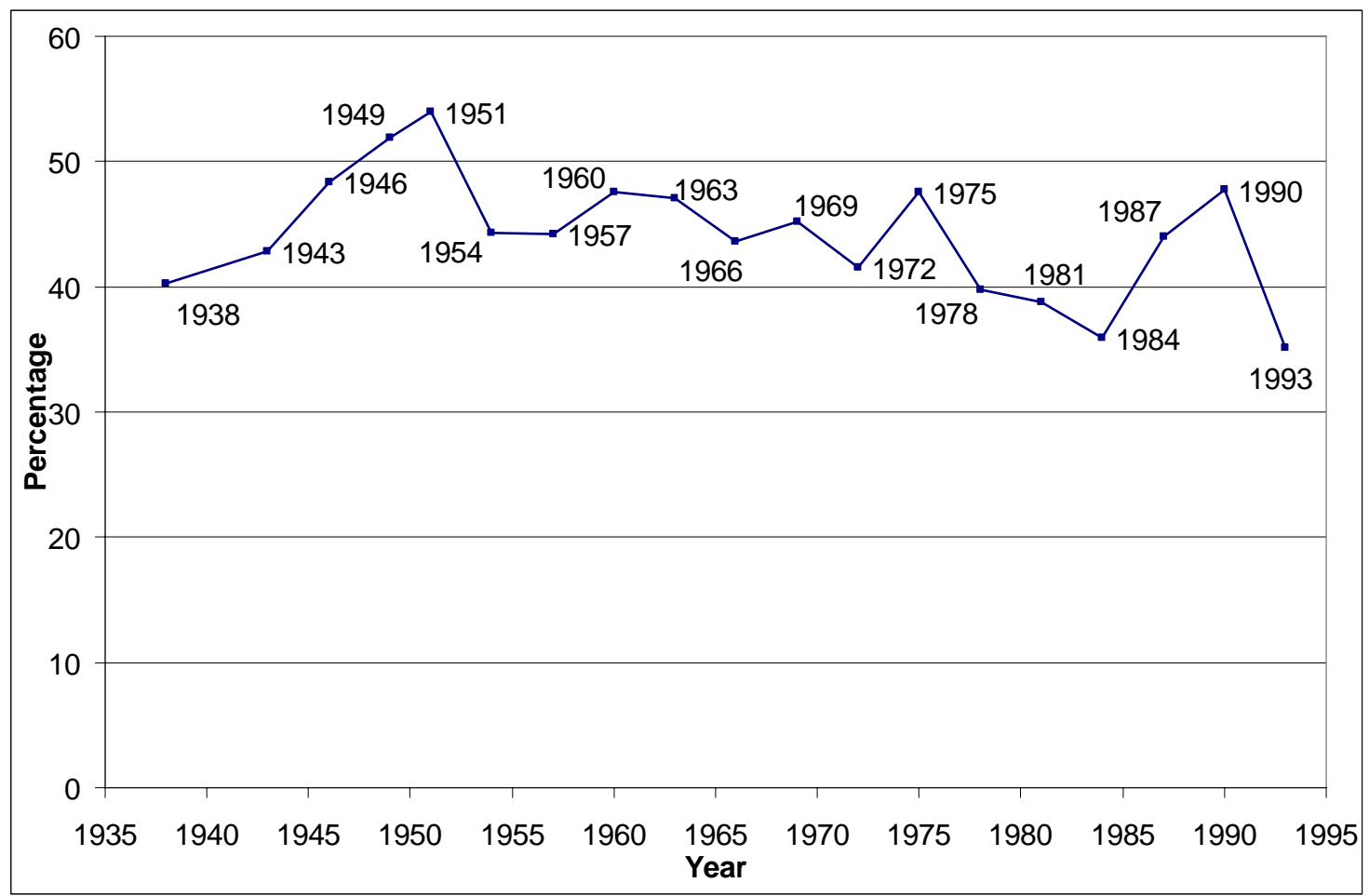

The 1993 election was conjointly held with a referendum on electoral reform, and the voters decided to change to MMP. MPs who were unhappy at the policy direction of the Party, or who risked losing their electorate seats (the number of electorates being reduced from 99 to 65), or both, could still have a reasonable chance of returning after the next election by forming their own political party. MPs left both major parties: National lost six of its 50 MPs, and Labour lost four of its 45 (during the previous term National had lost four MPs). ${ }^{22}$ The ten MPs that left National between 1990 and 1996 formed a variety of parties - all were conservative in nature indicating internal displeasure at the liberal agenda that had been implemented in the 1990-1993 period.

\footnotetext{
${ }^{21}$ Electoral Commission, "General elections 1890-1993 - seats won by party," Elections New Zealand, http://www.elections.org.nz/elections/FPP_seats_won.html, 2005 (accessed: 10 December 2007).

${ }^{22}$ For the 1993-1996 fragmentation, see: Jonathan Boston, Stephen Levine, Elizabeth McLeay, and Nigel S. Roberts, New Zealand Under MMP: A New Politics? (Auckland: Auckland University Press, 1996), 49-60.
} 


\section{Ideological Factionalism}

The history of the National Party shows that the ideological makeup of National was diverse, flexible, but reasonably stable. National was formed for strategic electoral reasons and while easily classifiable as a centre-Right party, further classification of the National Party in a single ideological paradigm proves difficult. The two main identifiable strands of thought within National are conservativism and liberalism, although there are also smaller libertarian and populist tendencies within National. ${ }^{23}$ However, the Party "generally presents itself as a hybrid party of the liberal/conservative type." 24 The divergent ideological bases for National have existed throughout its history.

The two strands found within National are ideologically at a disjunction. Part of the Party seeks to promote a free market society, while another part seeks to conserve a traditional order. Both strands stand in opposition to socialism and can be unified in seeking a property ownership society. However, ideology has never served as a strong platform for National. Indeed, "the National Party cannot ... secure electoral support for 'freedom' as such, without linking the concept to some concrete issue or proposal which is of interest to electors." 25 A pragmatic approach to politics had to be taken, which again served to limit the differing tendencies into accepting a compromise position.

\footnotetext{
${ }^{23}$ Colin James, "National," in Raymond Miller (ed.), New Zealand Government and Politics, (Auckland: Oxford University Press, 2006), 369; Colin James, "Ruth Amid the Alien Corn" (paper presented at the Bolger Years: The Seventh Parliamentary Conference, Wellington, 27-28 April 2007).

${ }^{24}$ Raymond Miller, Party Politics in New Zealand (Melbourne: Oxford University Press, 2005), 155.

${ }^{25}$ Milne, Political Parties in New Zealand, 285.
} 
As already shown, the formation of the National Party highlights the factionalism found throughout the history of National. Reform and United were ideologically distinct from each other. United, originally the Liberal Party, predominately represented liberal business and urban interests whereas Reform mainly represented the conservative countryside. Following on from the United/Reform split, and continuing through the $20^{\text {th }}$ century, the main split within the National Party has been an urban liberal/rural conservative divide. The ideological split within National has manifested itself in numerous manners.

From 1972 through to the MMP era the leadership switched between a liberal leader and a conservative leader (see Table 3.1). ${ }^{26}$ As the leadership rotated between factions, it indicated that the leadership was more than a random selection. One possible explanation for this phenomenon is that the factions, at some point, made an agreement to 'switch' leaders. However, no evidence of this exists, and given the high turnover of MPs in the New Zealand Parliament, ${ }^{27}$ such a deal would have become public knowledge. Instead, the 'factional rotation policy' arose out of the natural dissatisfaction that the 'out' faction had towards the 'in' faction - the 'out' faction became the driver for leadership change and built support from non-aligned MPs, especially if the leader was 'failing'.

\footnotetext{
${ }^{26}$ This point is alluded to early on in: Keith Jackson, "Political Leadership and Succession in the New Zealand National Party," Political Science 27, no. 1 \& 2 (1975).

${ }^{27}$ See: Elizabeth McLeay, "Representation, Selection, Election: The 2002 Parliament," in Jonathan Boston, Stephen Church, Stephen Levine, Elizabeth McLeay, and Nigel S. Roberts (eds.), New Zealand Votes: The General Election of 2002, (Wellington: Victoria University Press, 2003), 305-307; Elizabeth McLeay, "New Zealand: Parliamentary Careers and Electoral Reform," in Jens Borchet and Jürgen Zeiss (eds.), The Political Class in Advanced Democracies: A Comparative Handbook, (Oxford: Oxford University Press, 2003), 279.
} 
Table 3.1 The Factional/Ideological position of National's Leaders ${ }^{28}$

\begin{tabular}{|c|c|}
\hline Leader & Faction/Ideology \\
\hline Adam Hamilton, 1936-1940 & Conservative \\
\hline Sidney Holland, 1940-1957 (PM 1949-1957) & Conservative \\
\hline Keith Holyoake, 1957-1972 (PM 1957, 1960-1972) & Conservative \\
\hline John Marshall, 1972-1974 (PM 1972) & Liberal \\
\hline Robert Muldoon, 1974-1984 (PM 1975-1984) & Populist (Conservative) \\
\hline Jim McLay, 1984-1986 & Liberal \\
\hline Jim Bolger, 1986-1997 (PM 1990-1997) & Conservative \\
\hline Jenny Shipley, 1997-2001 (PM 1997-1999) & Liberal \\
\hline Bill English, 2001-2003 & Conservative \\
\hline Don Brash, 2003-2006 & $\begin{array}{l}\text { Liberal/Populist } \\
\text { (Conservative) }^{29}\end{array}$ \\
\hline John Key, 2006-incumbent & Liberal \\
\hline
\end{tabular}

Furthermore, the leader and deputy leader have usually represented different factions. Indeed, only three deputy leaders were of the same faction as the leader, and all were conservative-conservative matches (see Table 3.2). Again there is a clear suggestion that it is not a random distribution, but rather a systemic result that helped to ensure caucus stability. By ensuring that the dissatisfied faction (that which just lost the leadership) had control over the deputy leader, that faction could be assured that their policy positions were accounted for in decisions by the top. Furthermore, having a 'running mate' of a different faction widened the appeal of the leadership duo, not just

\footnotetext{
${ }^{28}$ More recent leaders are included so as to provide more data. George Forbes was temporarily leader from May to October 1936, and was never considered a formal leader. See: Gustafson, The First 50 Years, 14-17.

${ }^{29}$ Brash is an economic libertarian, yet he promoted largely populist conservative messages. On the face of it, Brash is an outlier for the 'factional rotation policy', but, given his political expediency with his own views, Brash's leadership is the exception that proves the rule. For the disjunction between Brash's personal beliefs and his policy see: James, "National," 371.
} 
in caucus but also to the electorate, and was thus more likely to be successful in leadership challenges and elections.

Table 3.2 The Factional/Ideological position of Leader and Deputy Leader ${ }^{30}$

\begin{tabular}{|c|c|c|c|}
\hline Leader & Faction & Deputy Leader & Faction \\
\hline Sidney Holland & Conservative & Keith Holyoake 1947-1957 & Conservative \\
\hline Keith Holyoake & Conservative & John Marshall 1957-1972 & Liberal \\
\hline John Marshall & Liberal & Robert Muldoon 1972-1974 & $\begin{array}{l}\text { Populist } \\
\text { (Conservative) }\end{array}$ \\
\hline \multirow{3}{*}{ Robert Muldoon } & \multirow{3}{*}{$\begin{array}{l}\text { Populist } \\
\text { (Conservative) }\end{array}$} & Brian Talboys 1974-1981 & Liberal \\
\hline & & Duncan MacIntyre 1981-1984 & Conservative $^{31}$ \\
\hline & & Jim McLay 1984 & Liberal \\
\hline Jim McLay & Liberal & Jim Bolger 1984-1986 & Conservative \\
\hline \multirow{2}{*}{ Jim Bolger } & \multirow{2}{*}{ Conservative } & George Gair 1986-1987 & Liberal \\
\hline & & Don McKinnon 1987-1997 & Liberal \\
\hline \multirow{2}{*}{ Jenny Shipley } & \multirow{2}{*}{ Liberal } & Wyatt Creech 1997-2001 & Conservative \\
\hline & & Bill English 2001 & Conservative \\
\hline Bill English & Conservative & Roger Sowry 2001-2003 & Conservative \\
\hline \multirow{2}{*}{ Don Brash } & \multirow{2}{*}{$\begin{array}{l}\text { Liberal/Populist } \\
\text { (Conservative) }^{32}\end{array}$} & Nick Smith 2004 & Conservative \\
\hline & & Gerry Brownlee 2004-2006 & Conservative \\
\hline John Key & Liberal & Bill English 2006-incumbent & Conservative \\
\hline
\end{tabular}

The ideological differences, while most obviously seen within the caucus, are spread throughout the Party's organisation. The organisation was split into five divisions in order to accommodate for the ideological differences and to help National win elections. The divisions each roughly corresponded to a factional body. Auckland and Wellington were liberal cities, while the rural areas were largely conservative. In splitting the factions away from each other through regional divisions, National has been able to decentralise the party to regional level and limit factional fighting.

\footnotetext{
${ }^{30}$ Again more recent leaders and deputy leaders are included to provide more data. The position of Deputy Leader was not instituted until 1947. Italics indicate where the leader and deputy leader represent the same faction/ideology.

${ }^{31}$ MacIntyre became Deputy Leader after the failed liberal 'Colonel's Coup', and the appointment of a conservative suggests a strong backlash against the liberal faction.

32 The appointment of both deputy leaders for Brash occurred before Brash struck a populist, conservative policy stance and he was still seen as a liberal leader.
} 


\section{Organisation}

While the National Party organisation changed over the years, most of the basic structure set up in 1936 still existed until the 2003 review. The original conference took many of the original ideas from the two merging parties, as well as copying the mass membership model found in Labour's organisation. At the formation conference chairman Colonel Claude Weston noted that, in order to be successful, National:

[R]ealised the vital necessity of continuity... a political organisation to be of the maximum assistance to its members must not be allowed to hibernate, only to wake up on the eve of an election. Like our friends of the Labour Party... we must work day and night; year in and year out. ${ }^{33}$

Much of the blame for the electoral defeat of the National Political Federation in 1935 was put on poor organisation, and the new National Party sought a strong organisation in order to counteract the perceived perfection of Labour's organisational structure. ${ }^{34}$

\section{Party Executive}

Initially the National Party had two governing bodies. The Dominion Council formally held considerable power, but the actual decisions were made by the Dominion Executive. Given the lack of power within the Dominion Council it was eventually scrapped in the 1985 re-organisation. Instead a new National Executive was formed. However, the central authority has never been strong within National.

\footnotetext{
${ }^{33}$ Quoted in: Gustafson, The First 50 Years, 10.

${ }^{34}$ Milne, Political Parties in New Zealand, 170.
} 
The Dominion Council was a large body with varying membership. In 1969 it consisted of 164 or 165 members - the President (elected by the Annual Conference), five male divisional vice presidents, two women vice presidents (one from each island), the Māori Vice President, the Dominion Treasurer (appointed by the Council), the Leader, five other MPs, 140 divisional representatives, two Young National representatives, six co-opted members, and, potentially, a past president. The large Council was designed to ensure that the Party elites were "closely in touch with the problems and needs of the Party throughout the country". ${ }^{35}$ Due to size of the Council and that it only met twice a year meant that the Dominion Executive became "a committee of the Council which, though technically subordinate, does in practise exercise virtually all the functions of Council." 36 The Dominion Executive consisted of just 19 councillors - the President, the Leader, the five male divisional vice presidents, the Dominion Treasurer, two MPs (usually including the Deputy Leader), a woman and a further eight councillors (usually including the divisional vice-chairs). Both the Council's and the Executive's membership changed over the years. In the 1984/5 review, the decision was made to disestablish the two separate bodies, and instead to have a National Executive. ${ }^{37}$

The National Executive was a body of twenty-six members. The Party President, nominated by one of the five Divisional Conferences and elected at the Annual Conference, was the formal chair of the Executive. Vice presidents arose from two different means - five vice presidents represented the division from which they were the Division Chairperson, while two were nominated by the Māori and women's

\footnotetext{
${ }^{35}$ New Zealand National Party, "The National Party Handbook," (Wellington: 1969), 79.

${ }^{36}$ New Zealand National Party, "The National Party Handbook," 80.

${ }^{37}$ Gustafson, The First 50 Years, 185.
} 
sections and then elected by the Annual Conference. The five deputy divisional chairs attended as did five other divisional council representatives. The caucus was represented by the Leader, Deputy Leader and two other caucus representatives. Finally, the Executive appointed a National Treasurer. While larger and more decentralised than the Dominion Executive, the National Executive was a more accurate representation of where power lay at the nationwide level (see Appendix One).

Even though the central body was at the formal top of the organisation, "the central governance was regarded by most of the Party as subsidiary to the divisional structures". ${ }^{38}$ Control of finances and membership were by the divisions, not the central executive. Given the relationship between the factions and the divisions, there was no desire to organise a strong collective body which would have had to deal with bridging the tensions between the rural conservatives and the urban liberals.

\section{$\underline{\text { Regional Divisions }}$}

The regional divisions had been allocated sufficient resources and influence that "it can be argued that the National Party is not a centralised single party but a confederation of five regional parties." ${ }^{39}$ The five regional divisions even had the ability to decide upon their own internal structure. However, the 1985 review made the divisional structures reflect that of the national structure, but also increased the powers each division had. ${ }^{40}$

\footnotetext{
${ }^{38}$ Subject B, Interview with Gregory R. Stephens, 14 June 2007.

${ }^{39}$ Gustafson, The First 50 Years, 205.

${ }^{40}$ Philip J. Clark, "The Impact of MMP on Political Party Electorate Organisations: A Case Study of National In Banks Peninsula" (MA, University of Canterbury, 1998), 68, 120.
} 
The five divisions had responsibility for much of the operation of the Party. The divisions had the responsibility for compiling membership data and collecting funds for the central body. Furthermore, the divisions were strongly represented in the central administrative board with each division having an ex officio vice president and a varying number of other representatives. The divisions were so powerful that they were able to prevent any significant central control over the Party.

Each division had its own unique characteristics. With the divisions corresponding to the factions within the Party, a degree of decentralisation is to be expected. If there was central control, then some divisions may have struggled to effectively campaign in their area and could have seen National lose more elections as voters sought out other political parties. The electoral pressure for National to form also created pressure for National to decentralise its operations in order to win elections.

Auckland and Wellington were the notably liberal divisions, although Auckland more so than Wellington. Auckland, which rejected the need to have professional staff, was "the major industrial and financial centre of the country... [and thus was] more socially and morally libertarian, and with a tendency to see things very much from an Auckland rather than a national perspective." ${ }^{41}$ Wellington, which had over one-third of all National members, included both urban and rural areas. The Wellington Division was dominated by Wellington City electorate members, many of whom became disillusioned under Muldoon and instead joined the liberal New Zealand Party in the 1984 election. $^{42}$

\footnotetext{
${ }^{41}$ Gustafson, The First 50 Years, 229.

${ }^{42}$ Gustafson, The First 50 Years, 216-224, 229-237.
} 
The conservative faction enjoyed divisional support from Waikato, CanterburyWestland and Otago-Southland. Waikato was the strongest division in percentage of seats held and the main urban area, Hamilton, developed as a farming support town and thus retained a rural conservative outlook. Canterbury-Westland, arguably the most conservative division, was highly influential within the Party, although National slowly lost influence in Christchurch as it became less reliant and linked to the rural areas. Otago-Southland was the smallest division with three distinct and largely autonomous areas separating off the 'lost cause' of Dunedin. However, the farming community largely dominated all three Divisions, ensuring that they were predominately conservative in outlook. $^{43}$

The divisions each had significant control over the campaigning within their area. By decentralising campaigning to divisional level, the Party ensured that message targeting was appropriate for each region. The rural conservative divisions were able to provide conservative messaging, whereas the urban liberal divisions could produce liberal messaging. There was even substantial decentralisation within divisions to the electorate-level. Decentralisation helped National win FPP elections.

\section{$\underline{\text { Social Divisions }}$}

While National has predominately focused upon geographical units of party organisation, three non-geographic divisions, based on social identity, have existed the Māori Advisory Committee, the Junior Nationals (later Young Nationals) and the

\footnotetext{
${ }^{43}$ Gustafson, The First 50 Years, 207-209, 209-216, 224-229.
} 
Women's Section. All three faced numerous battles for relevancy, official recognition and respect within the Party.

During the formation of National considerable debate was held over the role of Māori in the organisation and it was decided that a Māori Vice President be instituted, although it was unfilled until $1945 .{ }^{44}$ The Ratana-Labour alliance saw all four Māori seats elect Labour MPs in the post-war era. ${ }^{45}$ In 1946 the Dominion Māori Affairs Advisory Council formed, later changing its name to the Māori Advisory Committee. In 1974 the chairman of the Māori Advisory Committee became an ex officio Dominion Councillor - increasing Māori representation on the Dominion Council to two. The Māori Advisory Committee attacked the second National government's 1971 Race Relations Bill as imposing inaccurate racist perceptions - raising the question of whether Māori were relevant to the Party and vice versa. On numerous occasions, the Māori Advisory Committee, as well as Divisional and Dominion Conferences, have discussed the abolition of the Māori seats, although always coming to the decision that the fate of the Māori seats lay in the hands of Māori themselves, with the Māori groups acting as veto players. ${ }^{46}$

The Junior Nationals emerged out of the old Junior Reform League and quickly became active throughout the country. In 1957 it was decided by the division chairmen to organise the Juniors in divisions rather than electorates and encourage the formation of Junior advisory committees. Ten years later, the Juniors changed their name to the Young Nationals, created a national structure (with an annual conference and a national

\footnotetext{
${ }^{44}$ Gustafson, The First 50 Years, 12-13, 293.

${ }^{45}$ The first post-war break of Labour's Māori seat dominance was in 1993 by New Zealand First in Northern Maori.

${ }^{46}$ Gustafson, The First 50 Years, 241-255.
} 
executive) and took on a more political role. The 1968 National Party Dominion Conference gave the right for two Young Nationals to be members of the Dominion Council. The Young Nationals were largely liberal, especially on social/moral issues. ${ }^{47}$

National Party women began to not only organise themselves early, but also demand official recognition. At the 1938 Dominion Council meeting it was decided that each division should have at least one voting woman amongst its councillors. In 1940, token representation was given to National women, with two women vice presidencies (one from each island) being established, but were not on the Dominion Executive. It was not until 1974, when the Party merged the vice presidencies into one, that the Woman Vice President became a member of the Dominion Executive, and thus formally on par with the divisional vice presidents and the Māori section's vice president. Even then, the Woman Vice President had no formal support behind her such as the Māori Advisory Committee - it was not until the 1984/5 review that five divisional women's committees were formally established. The Women's Section was initially a conservative rural organisation, but during the 1970s and 1980s became more associated with liberal feminist views - although the Section's membership was by no means unified in their views. ${ }^{48}$

\section{Membership}

The National Party had a large membership, requiring substantial organisation. While no formal membership numbers were released, numerous estimates have been made.

\footnotetext{
${ }^{47}$ Gustafson, The First 50 Years, 255-266.

${ }^{48}$ Gustafson, The First 50 Years, 266-287.
} 
The highest estimated figure is 300,000 in the $1940 \mathrm{~s}$ and $1950 \mathrm{~s} ;{ }^{49}$ by the mid-1990s most estimates were lower than 50,000. Reportedly, at the 1949 election half of all National votes in the Saint Kilda electorate were cast by National members. ${ }^{50}$ No matter which estimates are correct, the trend has been that National has significantly lost party members since the 1950s and 1960s (see Appendix Three). The decline in membership was not specific to National within New Zealand, ${ }^{51}$ or New Zealand within the world. ${ }^{52}$ A belief existed within the Party that every member attracted three more National votes - hence declining membership numbers were of real concern to the Party. ${ }^{53}$

National membership figures are not as clear as the estimates put forward. Membership in National has been very open: in the 1950s minimum subscription rates were only two shillings and sixpence, alongside a loose definition of 'member' with little expectation on members to do more than vote and donate. ${ }^{54}$ Entire families were often signed up at one time and "it is quite possible for many members of the National Party to be unaware of the fact of their membership." ${ }^{, 55}$ The National Party was not only a political organisation, but a social grouping with numerous National Clubs set up throughout the country. ${ }^{56}$ In many rural areas the National Party provided one of the few entertainment facilities around. Consequently, even though National has often been

\footnotetext{
${ }^{49}$ Miller, Party Politics in New Zealand, 73.

${ }^{50}$ Gustafson, The First 50 Years, 208.

${ }^{51}$ Miller, Party Politics in New Zealand, 14.

52 Peter Mair and Ingrid van Biezen, "Party Membership Decline in Twenty European Democracies, 1980-2000," Party Politics 7, no. 1 (2001).

${ }^{53}$ Clark, "The Impact of MMP on Political Party Electorate Organisations", 115.

${ }^{5}$ Anthony Wood, "The National Party," in Hyam Gold (ed.), New Zealand Politics in Perspective, (Auckland: Longman Paul, 1992), 290, 298.

${ }_{55}$ Milne, Political Parties in New Zealand, 205.

${ }^{56}$ Gustafson, The First 50 Years, 237-240.
} 
thought of as one of the most successful political parties in terms of membership, ${ }^{57}$ there is little doubt that the figures have been inflated.

While party membership figures dropped significantly, theoretically those most likely to leave are not activists, but passive or social members. ${ }^{58}$ Consequently, the operation of the Party did not need to adjust due to falling membership figures - the Party's membership levels never fell below the critical point for its organisational operation. The Party has not felt the need to introduce new democratic measures to retain members, as some other political parties throughout the world have. ${ }^{59}$ While declining membership has been a significant vote share worry for National, it has not become an organisational problem.

\section{Caucus Separation}

Traditionally, the National caucus has been free of control from the extra-parliamentary party. The Party wanted to ensure that neither section ended up controlling the other and to remove the liberal/conservative divide from the membership. E.E. Hammond, the major architect of the initial Constitution and Rules, stated that:

The Organisation knows how to select its candidates without dictation from Parliamentarians. When the selected candidates win we say 'Goodbye' to them at the gates of Parliament. The Organisation has done its work

\footnotetext{
${ }^{57}$ Miller, Party Politics in New Zealand, 73-74; Gustafson, The First 50 Years, 82-83.

58 Susan E. Scarrow, "Parties without Members?: Party Organization in a Changing Electoral Environment," in Russell J. Dalton and Martin P. Wattenberg (eds.), Parties without Partisans, (Oxford: Oxford University Press, 2001), 95; Susan E. Scarrow and Burcu Gezgor, "Trends in Party Membership and Membership Participation: Smaller Parties, Different Types of Members?" (paper presented at the Midwest Political Science Association Annual Meeting, Chicago, 20-23 April 2006).

${ }^{59}$ See: Jonathan Hopkin, "Bringing the Members back in? Democratizing Candidate Selection in Britain and Spain," Party Politics 7, no. 3 (2001).
} 
in giving the necessary assistance; it is then up to the

Members to do their part as legislators, while we continue in our endeavour to add to their numbers. ${ }^{60}$

The extra-parliamentary party was given responsibility for funds, membership, campaigning and the selection of candidates. The caucus was given full control over parliamentary affairs, and shared policymaking and publicity with the extraparliamentary organisation. ${ }^{61}$ While there was formal separation, each section has, at some point, tried to gain more control over the Party as a whole.

The National Party sent their representatives to Parliament as trustees rather than delegates of the Party. The diverse nature of ideological views within National meant forcing MPs into one position was likely to result in significant internal conflict. National MPs were not bound to follow either the decision of the caucus or of the organisation, although they did have to sign that they will be "loyal to its organisation and chosen leader." ${ }^{62}$ Indeed, MPs were considered to be responsible to the nation rather than the Party. Yet caucus unity has been high with few dissentions on the floor. ${ }^{63}$ The extra-parliamentary party formally had no more sway over the caucus than any other interest group. ${ }^{64}$

In truth, the division between the two sectors of the Party was never clear. MPs had considerable sway over the extra-parliamentary party - they had resources such as

\footnotetext{
${ }^{60}$ Quoted in: Gustafson, The First 50 Years, 12.

${ }^{61}$ Gustafson, The First 50 Years, 10.

${ }^{62}$ New Zealand National Party, "Constitution and Rules of the New Zealand National Party," (Wellington: 1986), 46. Labour has long made candidates pledge that "I will vote on all questions in accordance with the decisions of the Caucus of the Parliamentary Labour Party", see: New Zealand Labour Party, "New Zealand Labour Party Constitution and Rules," (Wellington: 2003), 18.

${ }^{63}$ Indeed, crossing the floor has been incredibly low in New Zealand, see: Geoffrey Palmer and Matthew Palmer, Bridled Power: New Zealand's Constitution and Government, fourth ed. (Melbourne: Oxford University Press, 2004), 147.

${ }^{64}$ New Zealand National Party, "The National Party Handbook," 89.
} 
professional policy advisors available to them, as well as the weight of office behind them. Furthermore MPs attended Annual Conferences and had the right to speak and vote on remits and elections. The Leader was selected by the caucus but then had to be formally approved by the extra-parliamentary Executive. The Leader, Deputy Leader and at least one other caucus representative each held a seat on the Dominion Council and the Dominion Executive, and later the National Executive. Since 1994, the Party President has regularly attended caucus meetings to inform caucus of the feeling and happenings of the extra-parliamentary party. ${ }^{65}$ Predominately, a trend has been established seeing caucus slowly taking control away from the extra-parliamentary organisation.

\section{Electorate Candidate Selection}

One area in which the extra-parliamentary organisation formally held a veto over the caucus was candidate selection for elections. Candidate selection was heavily decentralised to the electorate level, thus allowing rural conservative electorates to select conservative candidates and urban liberal electorates to select liberal candidates, maximising the chances of winning each seat and keeping electorates unified behind their candidate.

Candidate selection was in the hands of the electorate itself, rather than the nationwide or divisional level. ${ }^{66}$ A selection meeting was held with one delegate for every 15 members of a branch. If the selection meeting did not have 60 delegates, or a branch

\footnotetext{
${ }^{65}$ Geoffrey Thompson, "Preparing the Party for MMP" (paper presented at the Bolger Years: The Seventh Parliamentary Conference, Wellington, 27-28 April 2007).

${ }^{66}$ Much of the academic work on electorate candidate selection has been done in the MMP era. However there were no changes to electorate candidate selection methods until 2003.
} 
did not select its full quota of delegates, then more delegates were selected by the Divisional Chair. The selectoral system was progressive elimination of the lowest polling candidate until one candidate had a majority. There was no representation of the Executive, and "there is no guarantee that the regional [divisional] chairperson will act according to the wishes of the party's headquarters when nominating top-up delegates."67 However, the Executive retained a veto right over all candidates selected and had weighting on a pre-selection meeting (since its introduction in 1973) which determined who the delegates may select between, with two of the nine members being selected by the President. Hence even though there was formal decentralisation towards the electorates, the central organisation played an important role in the process (see Appendix One).

The National Party candidate selection rules significantly benefited the incumbent MP. Up until 1986, only five successful public challenges to a sitting MP had been made, all in the Auckland Division. ${ }^{68}$ The 1993 election saw two MPs lose their seat due to deselection - Winston Peters, who fought, and failed, in court to prevent the National Executive vetoing his nomination for candidature in Tauranga; ${ }^{69}$ and Cam Campion, who was deselected by party members in Wanganui. Due to the large selectorate nominees needed to be well known and recognised - something an incumbent was more likely to be than a challenger. Furthermore, the "[i]ncumbent MPs are generally

\footnotetext{
${ }^{67}$ Rob Salmond, "Choosing Candidates: Labour and National in 2002," in Jonathan Boston, Stephen Church, Stephen Levine, Elizabeth McLeay, and Nigel S. Roberts (eds.), New Zealand Votes: The General Election of 2002, (Wellington: Victoria University Press, 2003), 196-197.

${ }^{68}$ Gustafson, The First 50 Years, 234.

${ }^{69}$ Peters vs Collinge, 2 NZLR 554 (1993); Hames, Winston First, 182-185.
} 
well placed to influence, if not control, the process of choosing delegates, with the result that their re-selection is all but guaranteed."70

Table 3.3 Women Candidates in National and Labour, 1946 to $1993^{71}$

\begin{tabular}{|c|r|r|r|r|r|r|r|r|r|r|r|r|r|r|r|r|r|}
\hline Party & \multicolumn{10}{|c|}{ Year (19xx) } \\
\hline & $\mathbf{4 6}$ & $\mathbf{4 9}$ & $\mathbf{5 1}$ & $\mathbf{5 4}$ & $\mathbf{5 7}$ & $\mathbf{6 0}$ & $\mathbf{6 3}$ & $\mathbf{6 6}$ & $\mathbf{6 9}$ & $\mathbf{7 2}$ & $\mathbf{7 5}$ & $\mathbf{7 8}$ & $\mathbf{8 1}$ & $\mathbf{8 4}$ & $\mathbf{8 7}$ & $\mathbf{9 0}$ & $\mathbf{9 3}$ \\
\hline Labour candidates & 2 & 3 & 2 & 5 & 3 & 5 & 5 & 6 & 4 & 6 & 6 & 13 & 11 & 13 & 23 & 28 & 33 \\
\hline National candidates & 2 & 3 & 4 & 3 & 4 & 5 & 2 & 3 & 5 & 4 & 5 & 6 & 10 & 11 & 10 & 17 & 19 \\
\hline
\end{tabular}

The candidate selection rules also had an impact on the ethnic and gender identity of National candidates. As Table 3.3 shows, few women have been selected as candidates for National. A similar pattern can be told for Māori (outside of the Māori seats) within National with only three successful Māori candidates up to $1986 .^{72}$ The majority of National candidates and MPs have been Pākehā males and "National fares very poorly in regards to representation of women and Māori MPs."73

\section{Preparations for MMP}

With the public firmly supporting MMP, the National Party had to look at what changes would be needed for the new electoral system. Most obviously, National would have to develop a new list selection process. However, further preparations and changes were hampered by President Geoff Thompson, who firmly believed that MMP should not be implemented. Thompson later noted:

\footnotetext{
${ }^{70}$ Miller, Party Politics in New Zealand, 114.

${ }^{71}$ Helena Catt, "Frail Success?: The New Zealand Experience Of Electing Women" (paper presented at the European Consortium for Political Research, Edinburgh, 2003).

${ }^{72}$ Gustafson, The First 50 Years, 242.

${ }^{73}$ David Boyd, "Party Candidate Selection Procedures and Objectives under MMP" (MA, University of Auckland, 1996), 82.
} 
I don't think anything was being done in caucus and it wasn't until about 1992 that a group of Party people initiated some brain storming about electoral change. Some of the talented 1990 Caucus intake, like Bill English and Roger Sowry, joined this group and the main effort went into figuring out how a party list of candidates would be developed. There was little thinking about how to capture the party vote in electioneering terms, or to reflect on the enormous changes in parliamentary strategizing that would be required to deal with the MMP system. $^{74}$

The list selection process implemented by National resulted from a working paper distributed and discussed throughout the Party. Three possible processes were analysed - the 'Regional Model', the 'Electoral College Model', and the 'Hybrid Model'. The 'Regional Model' would have been highly decentralised, with no central over-riding control of the list - the nationwide ordering would be done by a mechanical merging of the lists. The 'Hybrid Model' allowed each division to rank a regional list which would then have been merged into a national list by an electoral college made of both central and divisional representatives. Finally, the 'Electoral College Model' was more centralised with nominations being filtered by each division (for numerical purposes) but all ranking would be done by an electoral college similar to the membership of the National Executive. ${ }^{75}$

National decided upon the 'Hybrid Model' for list selection allowing the divisions significant, but not complete, control. Electorate candidate selection was to remain the

\footnotetext{
${ }^{74}$ Thompson, "Preparing the Party for MMP".

${ }^{75}$ National Party Electoral Reform Working Party, "The Emerging Picture: Party List and Constituency Selection: Discussion Paper - Mark II," (Wellington: New Zealand National Party, 1994).
} 
same and be independent of the list selection process. Each electorate would nominate two potential list candidates, and the Divisional Council would nominate one per electorate. The Divisional List Selection Meeting (with the same delegate rules as the Divisional Conference) would then rank its region's preferences using a preferential voting system. Each division was limited to a certain number of nominees, predetermined by the Executive on the basis of population. The divisional lists would then go to the List Standing Committee who would rank the entire list and the Committee "shall have regard to the ranking of Divisional nominations and the need for balance", 76 but need not be bound by it. The List Standing Committee comprised the Leader, Deputy Leader, President, seven vice presidents, a youth representative, and twenty divisional representatives (see Appendix One).

Apart from the introduction of a decentralised list selection process, National did little to prepare the Party for MMP. Partly, the lack of pre-MMP preparation was planned National was to review its organisation after the 1996 election. Partly, it was due to an anti-MMP President who wished to continue operating in a two-party system environment. Furthermore, it was unclear what changes MMP would bring to the National Party or even if it would need to change at all.

\section{The New Zealand National Party under FPP}

The New Zealand National Party has been highly successful in terms of membership figures and, more importantly, winning elections. However, the cost of successfully winning office and votes has been failing to implement policy in line with the

\footnotetext{
${ }^{76}$ New Zealand National Party, "Constitution and Rules of the New Zealand National Party," (Wellington: 1997), 67.
} 
ideological stance of the Party. Indeed, when National did favour policy over votes 1990-1993 - the Party had internal division and public distrust. National's vote and office seeking behaviour meant that the organisation was geared more towards campaigning than policy creation.

The electoral success of National hides its organisational failures well. From the 1950s, membership and vote share declined, the factional split remained unresolved with the regional divisions still fighting each other, the central executive needed to be reformed, the caucus began to dominate the organisation, and the candidate selection process limited the number of new MPs entering caucus. These problems did not manifest themselves in periods of victory and success, but when the organisation faltered they often resulted in open clashes. Only one open leadership challenge under FPP occurred while National was in office - the failed Colonel's Coup against Muldoon. After the formation period organisational reviews occurred in 1941, 1961, 1973 and 1984/5 - not surprisingly all but one of the reviews (1961) took place in a period of electoral defeat. While the National Party managed to successfully build an organisation to work in an FPP environment, it was an environment-specific solution to certain problems.

The National Party exhibited an organisation designed primarily around preventing an oligarchical national body from developing. Instead it promoted oligarchical regional divisions. National was a classic federalised party, and indeed was identified as being a stratarchical franchise organisation. ${ }^{77}$ While decentralisation places the decisionmaking procedures closer to the populous, it does not necessary make the process more

\footnotetext{
${ }^{77}$ R. Kenneth Carty, "Parties as Franchise Systems: The Stratarchical Organizational Imperative," Party Politics 10, no. 1 (2004).
} 
democratic. Many of the rules ensured democratic procedures where they were helpful to the party elites (such as candidate selection), but retained oligarchical control where the elites desired (for instance policy creation was largely in the hands of caucus). Although elites did have significant sway over some areas Gustafson labels National as "one of the most democratic, mass-based political party organisations the world has ever seen."78

The highly decentralised organisation was set up to combat Labour in a two-party single-member simply-plurality system. Decentralisation allowed for the divergent ideological strands to come together in one political party in order to win elections. The Party decentralised its activities so that it could compete throughout the country in the FPP environment, not in a MMP environment.

\footnotetext{
${ }^{78}$ Gustafson, The First 50 Years, $\mathrm{x}$.
} 


\section{Chapter Four: Defeat and Decline Under MMP}

The New Zealand National Party clearly had significant problems under MMP. The National Party recorded its worst results ever for four elections in a row, three of those being under the new electoral system. Several potential explanations are available for why National could not live up to its historical FPP record under MMP. While both National and Labour expected some degree of vote share decline, National was hit particularly hard when compared to Labour.

National measured success in terms of office and votes. ${ }^{1}$ However, the successful operation of any political party relies on many different factors. One of the key factors is how the party organises itself internally. Yet it is not just how it organises, but also the appropriateness of the organisational form for its environment. If National's decline was due to organisational inability to adjust to a new electoral environment then a re-organisation should be the appropriate response by National. But if the decline is for other reasons, then a re-organisation may fail to successfully deal with the causes of the decline in the long-term. National chose to respond to the decline with an organisational review in 2003.

\section{Decline, 1996-2002}

Even though most of the National Party opposed MMP, the Party's success under FPP meant that the Party had high expectations that they would continue to do well under

\footnotetext{
${ }^{1}$ There are other ways of defining success and the objectives of parties. See: Kaare Strøm, "A Behavioral Theory of Competitive Political Parties," American Journal of Political Science 34, no. 2 (1990).
} 
MMP. $^{2}$ While 1993 had been an electoral blow as National barely remained in government, there was little to hint that National's vote could slide further. The Party still had a base of support that it could rely on - the number of voters identifying as National for the 1996 election was up on $1993 .^{3}$ The campaign organisation was still geared up and the Party believed that people would give their two votes to the same party and that voters would treat the electorate vote as their primary vote. ${ }^{4}$ Hence the Party allowed National candidates to freely campaign for their electorate as that would maximise the party vote overall.

Leading up to the 1996 election, the National government was forced to form a variety of differing coalition arrangements as MPs left National in order to form their own political parties. In total, six of the 50 National MPs left to form new conservative political parties - none left to form liberal parties. While National was struggling internally, Labour was suffering externally, spending much of 1994 polling below the Alliance and a few months in 1996 polling below New Zealand First. ${ }^{5}$

The 1996 election saw National receive its lowest vote share in an election again, but Labour's vote share was its lowest post-war election result. National received just over one-third of all votes, and 44 of the 120 seats. After protracted negotiations National formed a coalition government with New Zealand First - a conservative, populist,

\footnotetext{
${ }^{2}$ For instance, see: Roger Sowry, "The National Campaign: Tactics and Strategies," in Jonathan Boston, Stephen Levine, Elizabeth McLeay, and Nigel S. Roberts (eds.), From Campaign to Coalition: The 1996 MMP Election, (Palmerston North: Dunmore Press, 1997), 31.

${ }^{3}$ Stephen Levine and Nigel S. Roberts, "Surveying the Snark: Voting Behaviour in the 1996 New Zealand General Election," in Jonathan Boston, Stephen Levine, Elizabeth McLeay, and Nigel S. Roberts (eds.), From Campaign to Coalition: The 1996 MMP Election, (Palmerston North: Dunmore Press, 1997), 191.

${ }^{4}$ Thompson, "Preparing the Party for MMP".

${ }^{5}$ Jack Vowles, "Countdown to MMP," in Jack Vowles, Peter Aimer, Susan Banducci, and Jeffrey Karp (eds.), Voters' Victory? New Zealand's First Election Under Proportional Representation, (Auckland: Auckland University Press, 1998), 16.
} 
protectionist party. ${ }^{6}$ The coalition agreement was ratified by the new National Party caucus with no formal consultation with, or agreement by, the extra-parliamentary party, although President Geoff Thompson was a member of the coalition negotiation team.

Trouble with New Zealand First and its Leader, Winston Peters, soon became obvious. The coalition agreement substantially favoured New Zealand First, especially in the allocation of cabinet seats. ${ }^{7}$ Several embarrassing scandals emerged, both personal (such as Tuku Morgan's (NZ First) infamous spending of government money on underwear) and policy (for instance, Minister of Health Bill English (National) and Associate Minister Neil Kirton (NZ First) clashed over health policy), which only served to fuel internal discontent in National. The internal dissatisfaction with Jim Bolger's handling of Peters and New Zealand First ended with Jenny Shipley taking the leadership from Bolger in December 1997.

Under the leadership of Shipley, National lurched towards the centre, even though Shipley herself was from the liberal Right-wing of National. ${ }^{8}$ With the collapse of the coalition in August 1998, ${ }^{9}$ National began to re-embark upon neo-liberal reforms, such as reforming accident compensation and introducing work-for-the-dole, although social

\footnotetext{
${ }^{6}$ See: Jonathan Boston and Elizabeth McLeay, "Forming the First MMP Government: Theory, Practice and Prospects," in Jonathan Boston, Stephen Levine, Elizabeth McLeay, and Nigel S. Roberts (eds.), From Campaign to Coalition: New Zealand's First General Election Under Proportional Representation, (Palmerston North: Dunmore Press, 1997); Fiona Barker, "Negotiating with New Zealand First: A Study of its Coalition Agreements with National and with Labour," in Jonathan Boston, Stephen Levine, Elizabeth McLeay, and Nigel S. Roberts (eds.), From Campaign to Coalition: New Zealand's First General Election Under Proportional Representation, (Palmerston North: Dunmore Press, 1997).

${ }^{7}$ Boston and McLeay, "Forming the First MMP Government," 237.

${ }^{8}$ Edwards, "Political Parties in New Zealand", 189-192.

9 Jonathan Boston, Stephen Church, and Hilary Pearse, "Explaining the Demise of the National-New Zealand First Coalition," Australian Journal of Political Science 39, no. 3 (2004).
} 
spending climbed (largely as a result of an increase in unemployment). Thompson publicly criticised the government for some of the neo-liberal reforms, especially their negative impact upon the farming community. ${ }^{10}$

The 1999 election was the third election in a row in which National lost vote share and recorded their worst result ever - a highly worrying trend. This time National lost office. National found itself facing an electorate weary of National and its policies, and also a Labour Party that accepted some of the major neo-liberal reforms that had taken place. $^{11}$ The heavy loss, followed by a string of low opinion polling results, saw the liberal Shipley replaced by the conservative Bill English in October 2001. The new leadership questioned the success of some of the neo-liberal reforms and indicated a belief that government spending was not necessarily an evil. ${ }^{12}$

Going into the 2002 campaign, National presented the most moderate platform it had had for several years. ${ }^{13}$ However the campaign was a disaster. National realised that the battle was not for government, but for relevance. ${ }^{14}$ Colin James identified several major flaws: English appeared to lack the credibility to be Prime Minister; National was not viewed as likely to be in government at any point; the campaign was poorly planned; and, the most telling flaw, policy was "muddled and/or insufficiently firm on a

\footnotetext{
${ }^{10}$ Thompson criticised the caucus on several occasions, see: Guyon Espiner, "Nat party chief criticises Govt over job losses," The Evening Post, 31 July 1998; New Zealand Press Association, "Heartland NZ gives National 'wake-up call' on rural policy," The Press, 11 May 1998; Peter Luke, "The trouble with ideology," The Press, 13 June 1998.

11 Raymond Miller, "Labour," in Raymond Miller (ed.), New Zealand Government and Politics, (Melbourne: Oxford University Press, 2003), 241-242, 246.

${ }^{12}$ Edwards, "Political Parties in New Zealand", 208.

${ }^{13}$ Edwards, "Political Parties in New Zealand", 208.

${ }^{14}$ Tim Grafton, "National's Campaign," in Jonathan Boston, Stephen Church, Stephen Levine, Elizabeth McLeay, and Nigel S. Roberts (eds.), New Zealand Votes: The General Election of 2002, (Wellington: Victoria University Press, 2003), 115.
} 
range of issues". ${ }^{15}$ Furthermore, the decision to 'retire' many long-serving MPs caused significant infighting within the Party. ${ }^{16}$ The party received 20.9 percent of the party vote, and just 27 seats within Parliament - the worst result in the history of the National Party for the fourth election in a row, and also a significant decrease compared to the last three elections.

Figure 4.1 National Party Valid Vote Share $1990-2002^{17}$

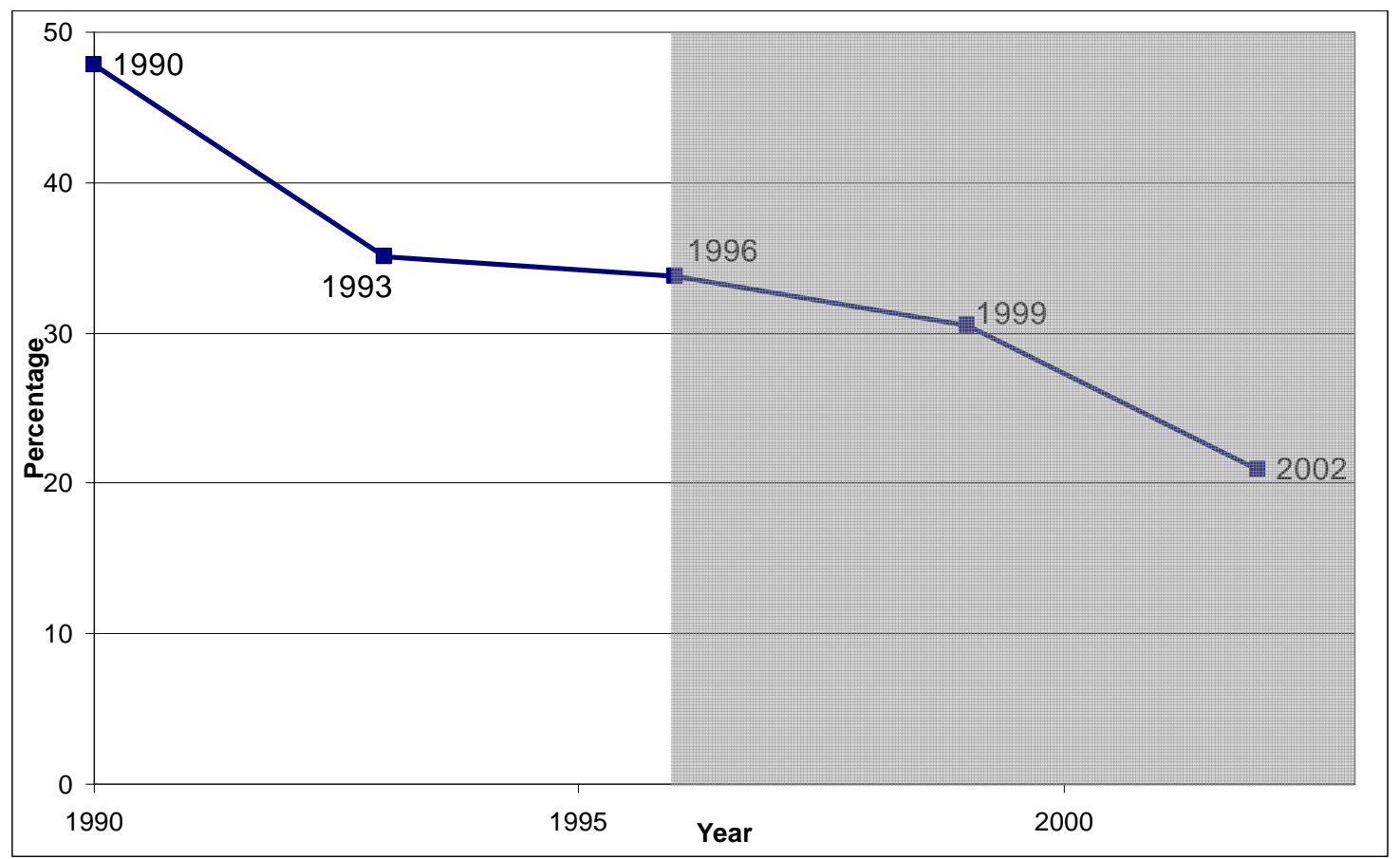

Any complacency that still existed within National of it being 'the natural party of government' was destroyed. For four elections in a row National had lost votes, each time recording a new low in the Party's electoral support (see Figure 4.1). For a party

\footnotetext{
${ }^{15}$ Colin James, "Two Million Voters in Search of a Rationale," in Jonathan Boston, Stephen Church, Stephen Levine, Elizabeth McLeay, and Nigel S. Roberts (eds.), New Zealand Votes: The General Election of 2002, (Wellington: Victoria University Press, 2003), 47.

${ }^{16}$ Andrew Geddis, "The General Election in New Zealand, July 2002," Electoral Studies 23, no. 1 (2004).

17 Electoral Commission, "General elections 1890-1993," ; Electoral Commission, "General elections 1996-2005 - seats won by party," Elections New Zealand, http://www.elections.org.nz/elections/article_126.html, 2006 (accessed: 10 December 2007).
} 
which prided itself upon winning office and votes, National had 'failed'. The 2002 election defeat was deeply felt, with Bill English noting "[t]his is the toughest lesson in how you have to be out there earning support every day." 18

\section{Explaining the Decline}

There are many plausible explanations for the significant drop of National's vote share since the introduction of MMP. These can be placed into three categories. Firstly, National's decline may be seen as a direct result of the new electoral system. Second, there are some explanations (such as leadership, trust, social and economic change) which have little to do with MMP - it is just sheer coincidence that they arose at the same time. While another, third, possible explanation is that the Party machinery operated poorly in the new electoral environment. There is no single stand-alone explanation as to why National declined so dramatically in the 1993-2002 period these three categories each provide some explanation to what happened. However, the organisational shortcomings were largely, and correctly, blamed in the 2003 review as being the major factor of decline. The decentralised structure was not set up for winning votes under MMP.

\section{$\underline{\text { MMP Factors }}$}

The introduction of MMP in 1996 was designed to break the hold the two main political parties had on parliamentary politics. FPP created a mechanical dominance for major

\footnotetext{
${ }^{18}$ Quoted in: Audrey Young and New Zealand Press Association, "Tears flow as 16 MPs say goodbye," New Zealand Herald, http://www.nzherald.co.nz/feature/story.cfm?c_id=774\&objectid=2347052, 2002 (accessed: 1 June 2007).
} 
parties, which then created a psychological dominance in the minds of voters. ${ }^{19}$ Labour and National both benefited from these factors under FPP.

With the removal of the mechanical dominance, both Labour and National should have experienced at least a seat share decline under MMP. FPP made "it difficult for small parties to gain representation.... all majoritarian systems tend to systematically favour the larger parties". ${ }^{20}$ Under MMP once a party is over the legal five percent or one seat threshold, the Sainte-Laguë formula (used to turn votes into seats) "treats all parties in an even-handed manner." ${ }^{21}$ If moving to MMP did not affect the preference of voters then Labour and National could expect a long-run seat share average of around 44 percent each. $^{22}$

Furthering the mechanical dominance, the psychological dominance of National and Labour was broken with the introduction of MMP. Not only did the main two parties benefit from the mechanical workings of the FPP electoral system, but that mechanical working had provided a psychological disincentive for electors. Voters did not wish to 'waste' their vote and voted for a major party, even if they simply saw it as voting for the 'lesser of two evils'. ${ }^{23}$ Hence with changing to MMP there was a reasonable expectation that both National and Labour should lose some votes to minor parties. The combined third party vote share ranged between 30 and 40 percent in the first three MMP elections. If all else remained equal, Labour and National could expect to each

\footnotetext{
19 Maurice Duverger, Political Parties: Their Organization and Activity in the Modern State, trans. Barbara North and Robert North (New York: John Wiley \& Sons, 1967 [1951]), 224, 226.

${ }^{20}$ Arend Lijphart, Electoral Systems and Party Systems: A Study of Twenty-seven Democracies, 19451990 (Oxford: Oxford University Press, 1994), 20.

${ }^{21}$ Lijphart, Electoral Systems and Party Systems, 157.

${ }^{22}$ National's post-war FPP vote-share average is 44.5 percent, while Labour's is 43.4 percent.

${ }^{23}$ Duverger, Political Parties, 226.
} 
receive around 30-35 percent of the vote. Yet National suffered considerable losses under MMP, with an average of 28 percent in the first three MMP elections, while Labour had an average of 36 percent in the same three elections. As Figure 4.2 shows, Labour did not suffer any considerable vote-share decline under MMP compared to what National experienced.

Figure 4.2 Labour Party Valid Vote Share 1935-2005 ${ }^{24}$

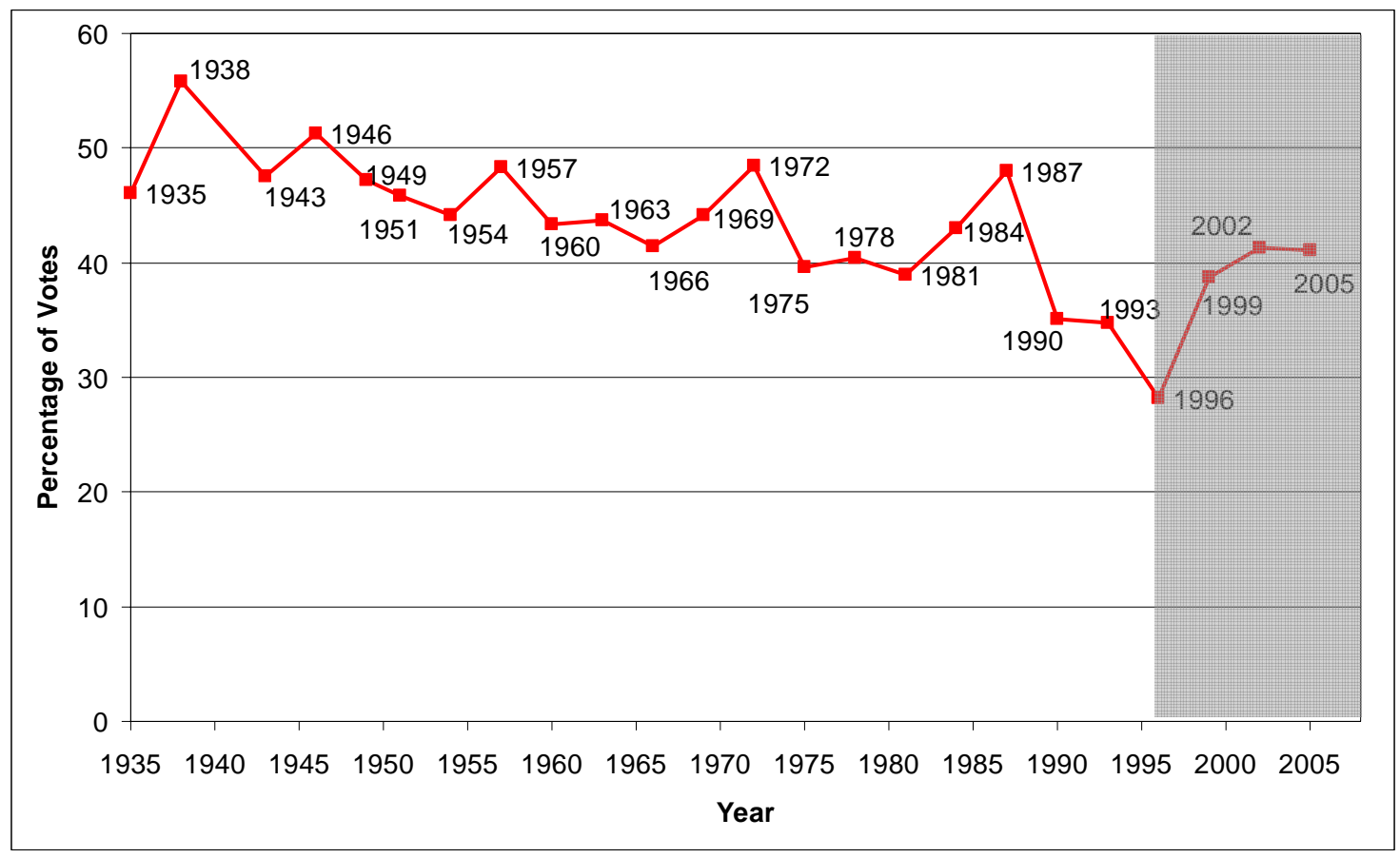

The multi-party system allowed voters to seek ideologically narrower parties, more aligned with their view point. Both Labour and National had to react to a system which, instead of promoting an ideologically homogenous party system as FPP had done, promoted an ideologically diverse party system. National, with liberal and conservative strands, had to cope with liberal ACT and conservative New Zealand First and United Future seeking to provide representation of liberal and conservative voters.

\footnotetext{
${ }^{24}$ Electoral Commission, "General elections 1890-1993," ; Electoral Commission, "General elections 1996-2005,"
} 
While Labour also had challengers (the Alliance, the Greens, the Māori Party, New Zealand First), it was better able to cope with the challenge. ${ }^{25}$

Labour's ability to cope with a new electoral system does raise questions as to why National could not cope. Indeed, Labour managed to go from a three-election decline to the longest period of Labour government rule (albeit in coalition) since the First Labour Government, beginning in 1999. Labour benefited from clever policy positioning pre-MMP ${ }^{26}$ a strong and flexible leadership, less internal division (ironically due to division and desertions in the 1980s), a centralised party organisation and an effective campaign strategy. ${ }^{27}$ Many factors worked against National during the reform period, and these provide non-MMP explanations as to why National declined.

\section{Concurrent Factors}

There is a wide range of possible reasons why a political party may decline. It is not unknown for a major, successful party to significantly lose votes and no longer be considered a major party - for instance in Canada the Progressive Conservative Party went from holding the second largest majority in Canadian history to holding on to just two seats in $1993 .^{28}$ Hence it is possible that the advent of MMP and the decline of the National Party are two unrelated events that simply occurred during the same era of politics. There is an array of plausible factors that might have led National to decline significantly in the 1990 s and early 2000 s no matter what the result of the MMP

\footnotetext{
${ }^{25}$ Gregory R. Stephens, "Factionalism in the New Zealand Labour and National Parties: The Challenges of Moving from a Two-Party System to a Multi-Party System" (paper presented at the New Zealand Political Studies Association Conference, Wellington, 30-31 August 2007).

${ }^{26}$ Fiona Barker, "Party Policy Positioning: The New Zealand Labour Party in Opposition 1990-1996" (MA, Victoria University of Wellington, 1998).

${ }^{27}$ Stephens, "Factionalism in the New Zealand Labour and National Parties".

${ }^{28}$ Lawrence LeDuc, "The Canadian Federal Election of 1993," Electoral Studies 13, no. 2 (1994).
} 
referendums. During the decline period National had weak leadership, faced a public weary of reform and distrustful of National, social change from both postmodernisation and urbanisation, and the 'third term blues'.

The leadership of the National Party between 1996 and 2002 was unstable and, at times, ineffective. The instability was caused by the factional rotation of leaders itself a product of the organisation. Furthermore, National had a tradition of removing unsuccessful leaders. $^{29}$ Jim Bolger led National to victory in 1996, but was replaced in 1997 by Jenny Shipley. While Shipley presented a new face for National, "she lacked the intellect and breadth to be a successful modern Prime Minister and failed to pull the party together and reconnect it [National] with its core vote." ${ }^{30}$ Shipley’s failure to win the 1999 election caused the caucus to replace her with Bill English in October 2001. English "was judged inferior to [Labour Leader Helen] Clark on every measure of leadership", 31 and failed to shine throughout the campaign with only 11 percent of voters rating him as their most preferred prime minister in one survey. ${ }^{32}$ However, leadership has not been a strong influential factor in New Zealand elections; with an effect of 1 to 3 percent in the pre-MMP era and of 4 percent in the 2002 election. $^{33}$ While leadership problems may have contributed to National's decline, the 2005

\footnotetext{
${ }^{29}$ Therese Arseneau, "The Defining Features of the 2005 Election: A 'Glass Ceiling' and 'Constitutional Innovation'," in Stephen Levine and Nigel S. Roberts (eds.), The Baubles of Office: The New Zealand General Election of 2005, (Wellington: Victoria University Press, 2007), 431.

${ }^{30}$ Colin James, "Comment: Ten Prime Ministers," Political Science 56, no. 2 (2004).

${ }^{31}$ Jon Johansson, "Leadership and the Campaign," in Jonathan Boston, Stephen Church, Stephen Levine, Nigel S. Roberts, and Elizabeth McLeay (eds.), New Zealand Votes: The General Election of 2002, (Wellington: Victoria University Press, 2003), 65.

${ }^{32}$ Stephen Levine and Nigel S. Roberts, "Consistent Patterns and Clear Trends: Electoral Behaviour in 2002," in Jonathan Boston, Stephen Church, Stephen Levine, Elizabeth McLeay, and Nigel S. Roberts (eds.), New Zealand Votes: The General Election of 2002, (Wellington: Victoria University Press, 2003), 320 .

${ }^{33}$ Clive Bean, "Party Leaders and Local Candidates," in Martin Holland (ed.), Electoral Behaviour in New Zealand, (Auckland: Oxford University Press, 1992), 150; Jack Vowles and Peter Aimer, "Political Leadership, Representation and Trust," in Jack Vowles, Peter Aimer, Susan Banducci, Jeffrey Karp, and Raymond Miller (eds.), Voters' Veto: The 2002 Election in New Zealand and the Consolidation of Minority Government, (Auckland: Auckland University Press, 2004), 181.
} 
election result under another 'weak' leadership, former Reserve Bank Governor Don

Brash, ${ }^{34}$ indicates that poor leadership was not a significant cause of National's decline.

Figure 4.3 Public Trust in the New Zealand National Party ${ }^{35}$

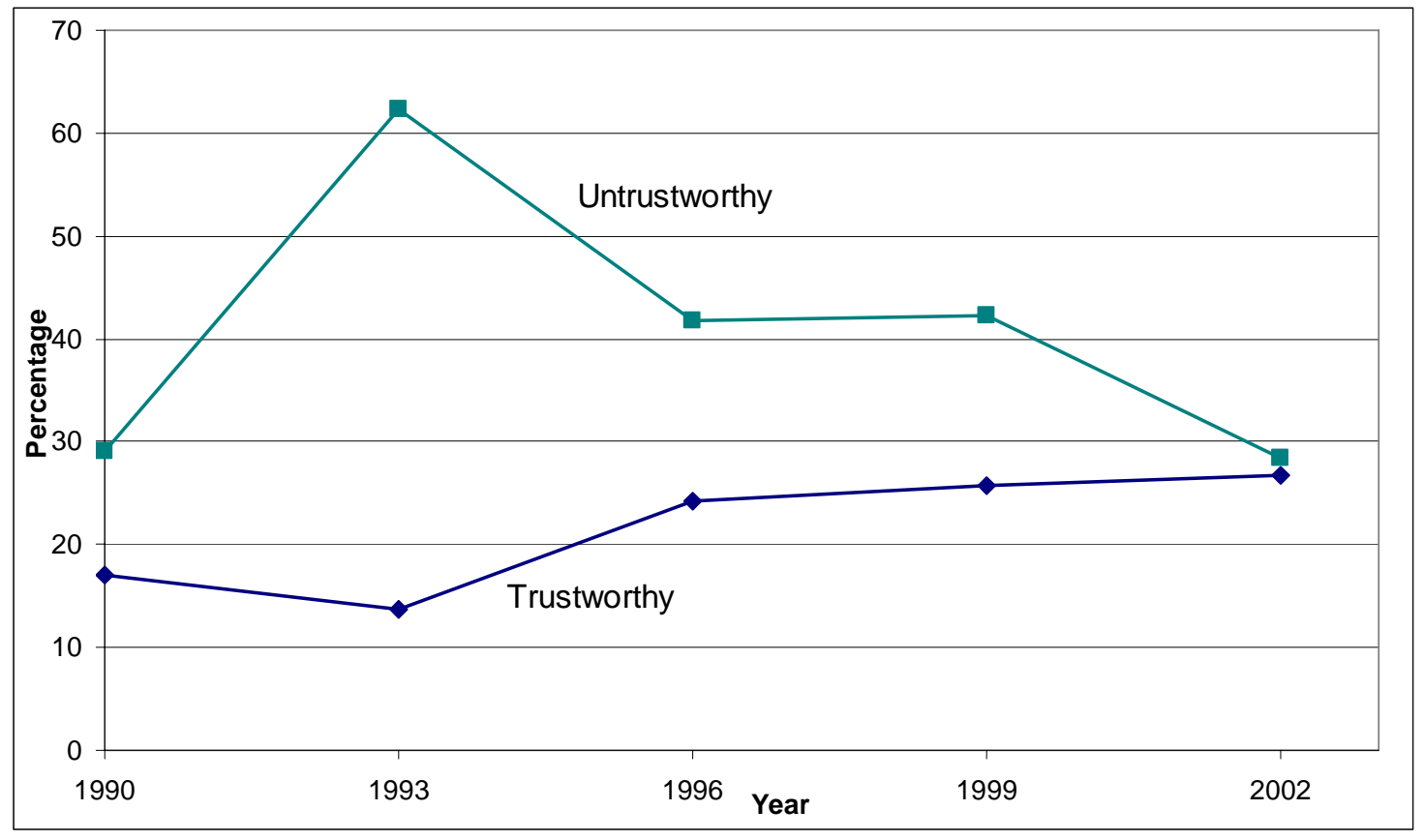

In the 1990-1993 period voters experienced a National government which failed to implement many key manifesto policies, and implemented some contrary policy

\footnotetext{
${ }^{34}$ See: Stephen Levine and Nigel S. Roberts, "Mixed Messages: Voting Behaviour in New Zealand in 2005," in Stephen Levine and Nigel S. Roberts (eds.), The Baubles of Office: The New Zealand General Election of 2005, (Wellington: Victoria University Press, 2007), 366-370.

${ }^{35}$ There are minor variations in the question asked between different elections. All survey data is from the New Zealand Election Study. See: Jack Vowles and Peter Aimer, Voters' Vengeance: the 1990 Election in New Zealand and the Fate of the Fourth Labour Government (Auckland: Auckland University Press, 1993), 148; New Zealand Election Study, "Democracy, Parties, and the Political System, 2002," New Zealand Election Study, http://www.nzes.org/exec/show/freq 2002b, 2002 (accessed: 5 September 2007); New Zealand Election Study, "Democracy, Parties, and the Electoral System, 1999," New Zealand Election Study, http://www.nzes.org/exec/show/freq_1999b, 1999 (accessed: 5 September 2007); New Zealand Election Study, "Party Preferences and Voting, 1996," New Zealand Election Study, http://www.nzes.org/exec/show/freq_1996e, 1996 (accessed: 5 September 2007); New Zealand Election Study, "Campaign and Issues, 1993," New Zealand Election Study, http://www.nzes.org/exec/show/freq_1993a, 1993 (accessed: 5 September 2007). For the 2005 results, showing a further increase in trust, but also an increase in untrustworthy, see: New Zealand Election Study, "2005 NZES: Section B Frequencies," New Zealand Election Study, http://www.nzes.org/exec/show/freq 2005b, 2005 (accessed: 5 September 2007).
} 
instead. ${ }^{36}$ For instance, National increased the superannuation surtax rather than removing it altogether. The further liberalisation of the economy, including the sale of state assets and significant welfare reforms, led many voters to distrust the National Party. ${ }^{37}$ Distrust in a political party is likely to lead to decline, although trust can be rebuilt. Yet National became more trusted as its vote share fell (see Figure 4.3). If lack of trust were the primary cause for National to lose votes in 1993, then the reemergence of trust in National should have reversed the decline, but it did not. As a result distrust can largely be discounted as a long-term factor in National's decline.

Another theory is that voters became increasingly weary of the neo-liberal reforms and voted for other parties to stop reforms. During this period National favoured policy over votes and office and suffered the repercussions of doing so. Significant changes to economic structures created upheaval. The neo-liberalisation period saw many reforms which impacted upon New Zealanders. Substantial reforms had begun in the 1980s and had continued through to 1999 . The New Zealand public was left feeling that it was 'time for a change' (or more precisely 'time to stop change'). ${ }^{38}$ Yet reform stopped with the election of the Labour-led government in 1999, while National's worst defeat was 2002. While it could be fair to argue that the 2002 result was so low because voters did not want to re-start the reform process, if that was the case then the 2002 result should not have been substantially below the 1999 result.

\footnotetext{
${ }^{36}$ Colin James, "Rogernomics-Plus with Ruth," in Colin James and Alan McRobie (eds.), Turning Point: The 1993 Election and Beyond, (Wellington: Bridget Williams Books, 1993), 32-63.

${ }^{37}$ Bale and Roberts, "Plus ça change...?."; Colin James, "Assessing the Issues," in Jonathan Boston, Stephen Church, Stephen Levine, Elizabeth McLeay, and Nigel S. Roberts (eds.), Left Turn: The New Zealand General Election of 1999, (Wellington: Victoria University Press, 2000), 70.

${ }^{38}$ James, "Assessing the Issues," 69.
} 
Ronald Inglehart notes that in advanced industrial societies "emphasis on economic security and economic growth is giving way to an increasing emphasis on the quality of life." 39 The values that society elects politicians on changed - social/moral issues became more important to voters. The National Party's two strands - liberal and conservative - were on differing sides of the 'post-modern' political spectrum. A political party attempting to appeal to both sides of the political spectrum can expect little serious voter attention and would expect to decline. However, 'modern' issues such as the economy, education and health still dominated election surveys of the most important issues facing New Zealand. ${ }^{40}$ Furthermore, the social liberal-conservative divide in New Zealand correlated with the economic Left-Right divide due to a 'deep structure' in New Zealand politics. ${ }^{41}$ As 'post-modern' issues were second-tier and largely correlated with the pre-existing political spectrum they only had a slight impact upon voting behaviour, and cannot be responsible for National's decline.

Urbanisation has been steadily occurring since 1886, and since the 1960s urban areas have comprised more than 80 percent of the population. ${ }^{42}$ One of National's core support groups was in decline and National responded by placing more weight on urban

\footnotetext{
${ }^{39}$ Ronald Inglehart, Modernization and Postmodernization: Cultural, Economic, and Political Change in 43 Societies (Princeton, New Jersey: Princeton University Press, 1997), 325.

40 Jack Vowles, "Estimating Change During The Campaign," in Jack Vowles, Peter Aimer, Susan Banducci, Jeffrey Karp, and Raymond Miller (eds.), Voters' Veto: The 2002 Election in New Zealand and the Consolidation of Minority Government, (Auckland: Auckland University Press, 2004), 43; Jack Vowles, "Did the Campaign Matter?," in Jack Vowles, Peter Aimer, Susan Banducci, Raymond Miller, and Ann Sullivan (eds.), Proportional Representation on Trial: The 1999 New Zealand General Election and the Fate of MMP, (Auckland: Auckland University Press, 2002), 23; Richard Johnston, "Issues, Leaders, and the Campaign," in Jack Vowles, Peter Aimer, Susan Banducci, and Jeffrey Karp (eds.), Voters' Victory? New Zealand's First Election Under Proportional Representation, (Auckland: Auckland University Press, 1998), 73.

${ }^{41}$ Jack Vowles, "Patterns of Public Opinion," in Jack Vowles, Peter Aimer, Susan Banducci, Jeffrey Karp, and Raymond Miller (eds.), Voters' Veto: The 2002 Election in New Zealand and the Consolidation of Minority Government, (Auckland: Auckland University Press, 2004), 125, 127-128.

42 Statistics New Zealand, "New Zealand: An Urban/Rural Profile," http://www.stats.govt.nz/NR/rdonlyres/A2FDF8E9-32AD-487D-AEE7-

040F513EE777/0/NZUrbanRuralProfile2.pdf, 2004 (accessed: 20 August 2007).
} 
issues and policy. National faced a wave of discontent from rural voters put off by National's deregulation policies, especially of the producer boards. ${ }^{43}$ The percentage of all MPs from a farming background markedly dropped from 17 percent in 1990 to just eight percent after the 2002 election. $^{44}$ National lost support in rural areas - in 2002 Labour won the plurality of the party vote in 65 of the 69 electorates. Yet, three of the four seats where National won the plurality in 2002 were rural seats and "National continued to command broad support across most of the rural seats." National was still the only party significantly active in seeking rural conservative voters and National's decline also came from urban voters moving to new political parties.

National suffered from the 'third term blues'. Governments have tended to lose votes over the term in office (Figure 4.4). Governments may find that they are unable to implement key policies as they are unworkable, or the policies which are implemented may have a negative impact on some voters. Furthermore, the longer a party is in government the rarer fresh ideas and faces are and the harder it becomes to blame problems on the previous government. However, the Fourth National Government had a larger decline than any other government, with the defeat election 17.3 percent lower than the office-winning election. Further, in five out of eight governments since $1935,{ }^{46}$ that particular party revived its fortunes at the next election - the exceptions being the First Labour Government (drop of 1.4 percent), the Fourth Labour Government (drop of 0.4 percent) and the Fourth National Government with a

\footnotetext{
${ }^{43}$ James, "Assessing the Issues," 74; Megan K.L McKenna, "Can Rural Voices Effect Rural Choices? Contesting Deregulation in New Zealand's Apple Industry," Sociologia Ruralis 40, no. 3 (2000).

${ }^{44}$ Raymond Miller, "Who Stood for Office, and Why?," in Jack Vowles, Peter Aimer, Susan Banducci, Jeffrey Karp, and Raymond Miller (eds.), Voters' Veto: The 2002 Election in New Zealand and the consolidation of minority government, (Auckland: Auckland University Press, 2004), 97.

${ }^{45}$ Miller, Party Politics in New Zealand, 56.

${ }^{46}$ The Labour-led government (1999-200[8]) is excluded as it is still in office at the time of writing.
} 
considerably larger drop of 9.6 percent. While 'third term blues' contributed to the decline it fails to explain the unusually large drop in vote share National experienced both in and out of government in the 1990s and early 2000s.

Figure 4.4 Indexed Declining Valid Vote Share of Governments ${ }^{47}$

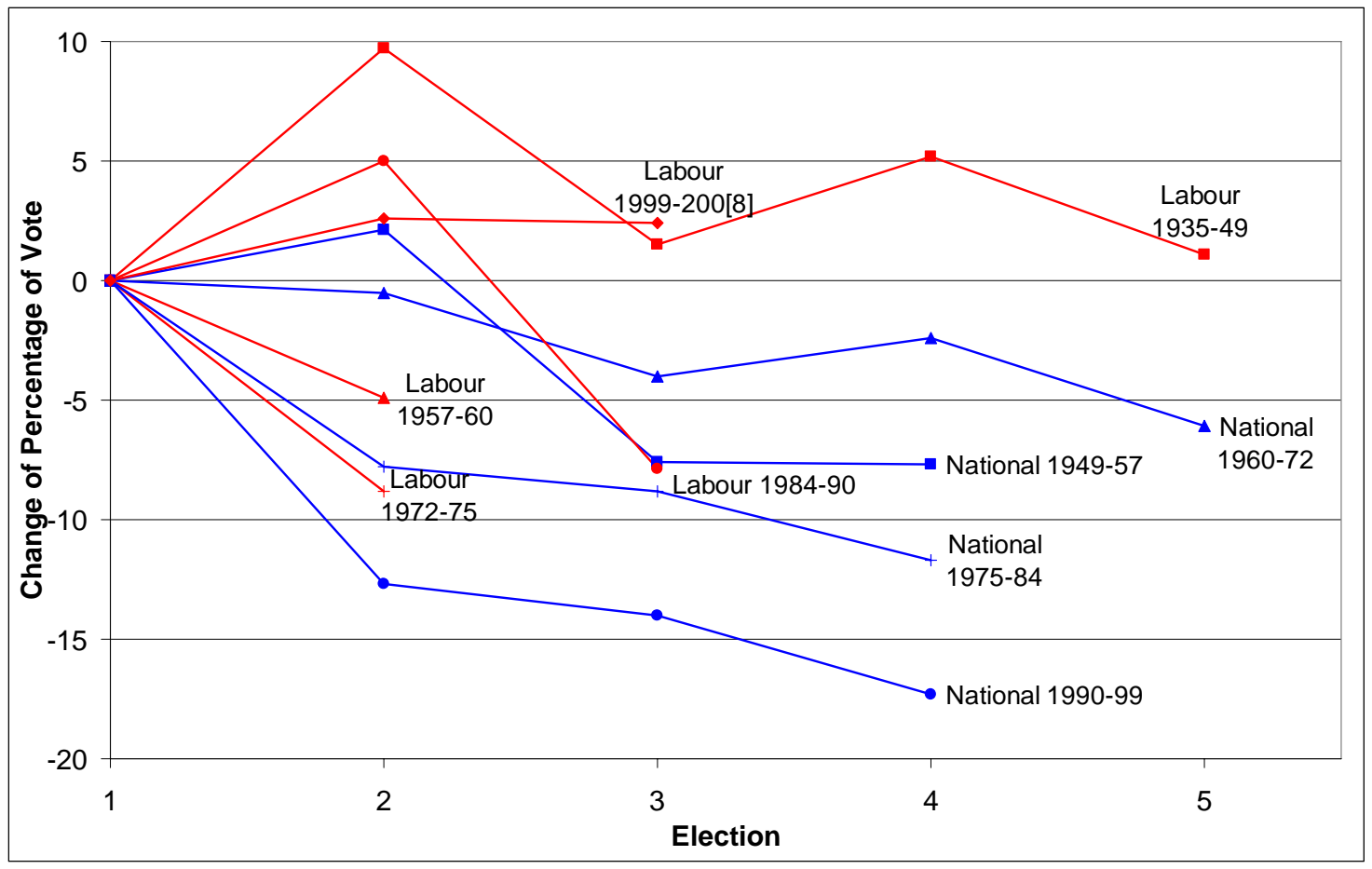

While these factors all contributed to a significant decline within National, most of them have been dealt with at some stage before. National has had an array of leaders, some of whom were less capable than others. The main value system has been slowly shifting and social issues were at the forefront during the 1970s. Urbanisation has been a constant factor in New Zealand society, with the majority of New Zealanders living in cities since the early twentieth century. The 'third term blues' has been faced by all

\footnotetext{
47 All governments since 1935. First election result indexed to zero, showing the percentage of vote change since the first election. The last election result shown (except for Labour-led coalition government 1999-200[8]) is the defeat election of the government. MMP governments exclude coalition partners and only deal with National and Labour. Data originally from: Electoral Commission, "General elections 1890-1993," ; Electoral Commission, "General elections 1996-2005,"
} 
previous governments. Distrust in National seems to be the sole challenge not previously faced, but it too can be discounted as a long-term factor in National's decline. The vote share decline can be largely attributed to some other factor - and again the introduction of the MMP electoral system rises as a variable in explaining National's decline.

\section{Organisational Factors}

The National Party has operated at a decentralised level since its formation in 1936. The electoral reform process brought in a new form of electoral system and hence a new environment. The 'appropriateness' of an organisational setup for a given environment has a significant impact upon the successfulness of that organisation. National's organisation did not have the capacity to create a national list or conduct a nationwide campaign which would attract party votes.

While National's organisation was highly successful in FPP, under MMP the organisational structure was untested. The decision to make minimal changes before MMP largely resulted from an inability to see the new electoral system as requiring a new organisation, combined with President Geoff Thompson's dislike of MMP. However, the new MMP environment differed from FPP in a number of crucial ways in relation to the operation of political parties. National's candidate selection, campaign structure and ideological factionalism all were problematic under the new electoral environment and made it difficult for National to attract votes. 


\section{Candidate Selection $^{48}$}

FPP and MMP require different forms of candidates. As FPP operates in singlemember constituencies, it largely requires candidates which can appeal to the plurality in each seat. Hence a decentralised selectorate is likely to be able to appoint 'appropriate' candidates. MMP though requires a nationwide candidate pool which appeals to different sectors of society through ethnic, gender and identity representation. Thus MMP requires a centralised selectorate and nomination process to ensure that the list is balanced enough to appeal to different groups.

National grafted its list selection process to the already existing electorate candidate selection method. The two candidate selection processes were parallel - to be a candidate on one did not indicate being a candidate on the other. Nominations for the list were decentralised and in the hands of electorates and divisions. There was no incentive for electorate candidates to present a 'two ticks' campaign and some were able to present just solely an electorate vote campaign in their electorate.

National did not enforce dual candidacy, in order to potentially allow the two candidate pools to reflect the 'appropriate' form of candidate for each tier. Yet National also decentralised the nomination process for the list thus leading to a lack of social identity candidates on the list. Only fourteen percent of National candidates were of Māori, Asian or Pacific Island descent; only 21 percent were female. While there were some exceptions, the social characteristics of the list largely failed to represent the social profile of New Zealand-as-a-whole. Instead the list was predominately comprised of Pākehā males. The list and electorate process resulted in the possibility that voters may

\footnotetext{
${ }^{48}$ See Chapter Five for further in-depth discussion and supporting evidence.
} 
not be attracted by the list candidate pool, but felt that the electorate candidate was attractive. Furthermore, the decentralisation of nominations effectively ensured that factional candidates were selected rather than compromise, or non-factional, candidates.

The factional nomination was reinforced by the strong divisional representation on the selectorate. Combined, they created an informal regional quota system. As the divisions were strongly linked to the factions there was a need for balance between the liberal and conservative factions. The divisions fought for each position between themselves, largely ignoring other important elements. While there were representatives of Māori, women and youth on the List Standing Committee, they were much weaker than the divisions and did not necessarily have candidates to support due to the decentralised nomination process. The lists were largely based upon regional quantity rather than candidate quality.

Each electorate largely looked after the vote campaign which would maximise their own candidate's chances of getting elected. There was no over-riding consideration for the state of the Party-as-a-whole. The belief that electorate MPs were more legitimate than list MPs largely meant that the preferred option in entering Parliament was under the electorate method. The incentives created by the nomination process and the twotiered nature of MMP meant that National had trouble controlling electorate campaigns. It is no surprise that in the 1996, 1999 and 2002 elections National recorded a higher overall electorate vote share than party vote share (see Figure 6.8). 
National did have significant candidate selection problems in the 1996, 1999 and 2002 elections. As theorised earlier, introducing candidate selection methods for the list posed a problem for National. For a political party which had operated at a decentralised level, the decision to allow electorates and divisions to control nominations and the decision to have strong divisional representation on the selectorate were easy to make. However, the decisions made were not the best for appealing throughout the country. National suffered in the party vote due to the inappropriateness of list candidates for the nation and the incentives of electorate candidates to present an electorate vote-centric campaign. Decentralised candidate selection meant National did not have the capacity to put forward a list which would attract party votes throughout the country.

\section{Campaign Structure ${ }^{49}$}

The change to MMP necessitated a different form of campaigning than that which existed previously. As previously noted, MMP requires a nationwide campaign, whereas FPP requires a decentralised campaign focused on marginal seats as the fulcrum of the campaign. However, National's organisational structure limited the ability of Party elites to run a nationwide campaign, instead electorates continued to determine how campaigning would occur in their small geographic unit.

Electorate committees were still the dominant force in making decisions about campaigning in elecorates. There was no over-riding campaign. Each electorate was able to run what it viewed as the 'best' campaign for the electorate. MMP though

\footnotetext{
${ }^{49}$ See Chapter Six for further in-depth discussion and supporting evidence.
} 
requires a nationally consistent campaign. Each elector's party vote is of equal value to all others.

The decentralised control prevented National from hiring professional staff. As divisions have traditionally hired most campaign staff, the central authority could not hire a professional campaign adviser, and when they did (2002) they were ineffective in communicating to the electorates and divisions - who wished to control the campaign themselves. Furthermore, financially the divisions and electorates were strong, and as they provided money to the central campaign team, they were able to have some control over the use of that money.

National's decentralised organisation further limited any nationwide strategy being implemented. MMP requires parties to focus resources more evenly throughout the country than FPP. However, electorates predominately focused upon marginal swinging voters rather than building the coalition of voters needed. Where there was a nationwide strategy, it was an FPP two-party system strategy rather than an MMP multi-party system strategy.

Electorates were able to control advertising in their own district. There was no central control or approval needed. In the 1996, 1999 and 2002 elections numerous problems were found. Billboards did not ask for the party vote, and some even failed to mention National. Pamphlets were produced in a wide variety of colours and forms, again some failing to push the party vote aspect. Radio was used by candidates, outside of the ninety day regulation period, to push the candidate not the party. The only nationwide 
medium, television, was used by the centre, but failed to be effective as it could not, and did not, link in with the other campaigns occurring throughout the country.

The electorate-level campaign was highly personalistic and candidates maintained separate campaign organisations which undermined the party/issue oriented campaign that the central campaign team attempted to push in all three elections. National did not run an MMP-specific campaign in any of the three elections. There was no focus on the Party-as-a-whole or the party vote. Instead, the campaign structure allowed too much control for electorates and the central campaign team did not have the ability to over-ride them and run a nationwide campaign. The decentralised campaign structure meant National did not have the ability to run a campaign which would attract party votes throughout the country.

\section{Ideological Factionalism}

The decentralised nature of National allowed the factional nature of the Party to solidify and institutionalise itself. Under FPP this was a sensible decision - the liberal and conservative wings appealed to different sectors of society. Under MMP the array of different political parties for whom it is possible, and viable, to vote for makes ideological heterogeneity a burden and a challenge for a party rather than a potential vote-winning facet. ${ }^{50}$

Under FPP National did not have difficulty in providing a link between the liberal and conservative factions and could largely allow each free rein in the extra-parliamentary party. With the introduction of MMP National could no longer advertise itself as

\footnotetext{
${ }^{50}$ Stephens, "Factionalism in the New Zealand Labour and National Parties".
} 
simply being the 'anti-Labour' party, given the existence of other actual and potential anti-Labour political parties. Under FPP National's core beliefs were outlined in a negative statement (anti-Labour), but under MMP such statements had to shift in order to become positive. Hence National had to actively define itself and what the Party stood for under MMP - yet in doing so National risked alienating one faction or the other.

Figure 4.5 New Zealand Political Spectrum (post-2002 election) ${ }^{51}$

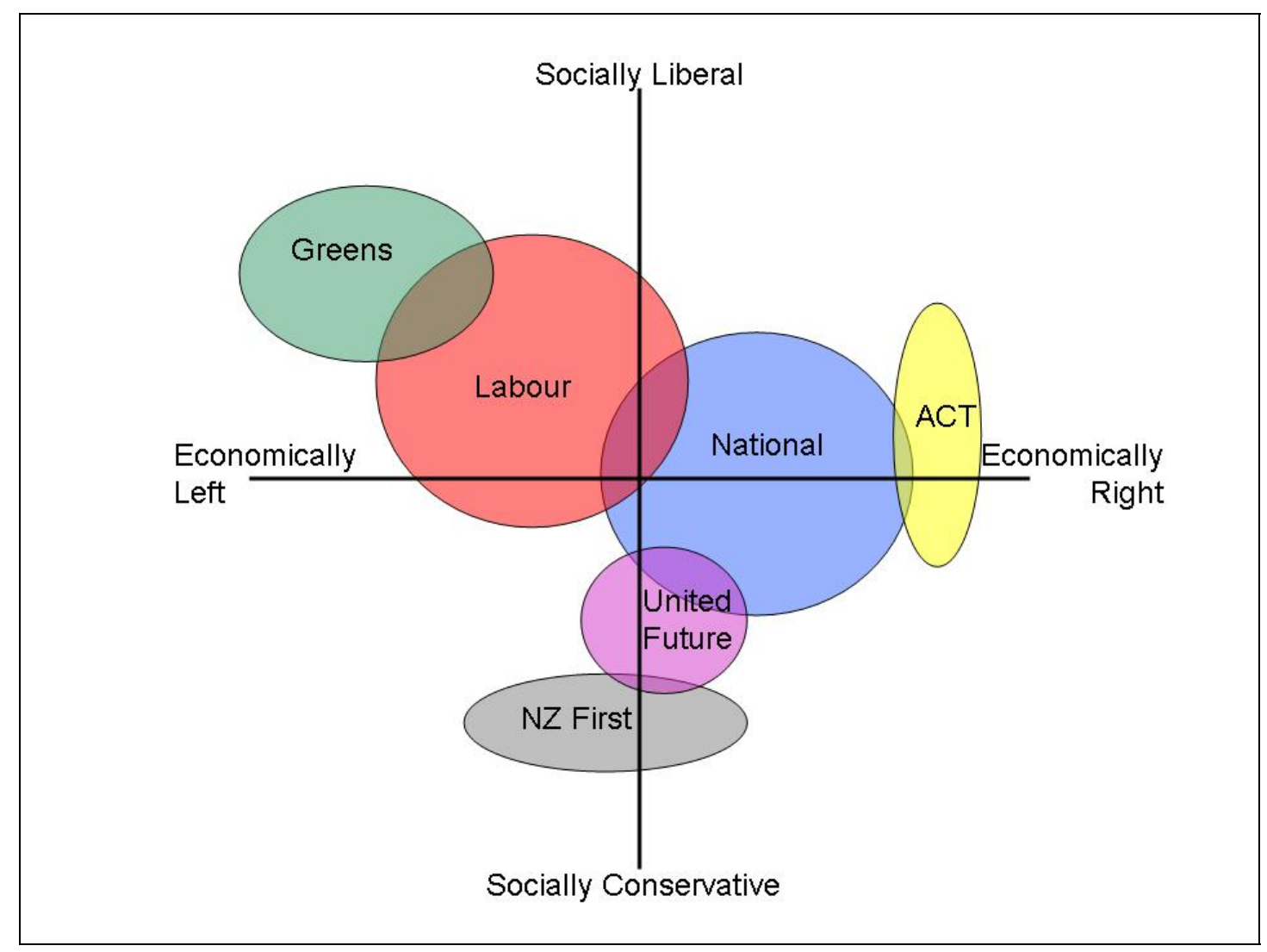

Minor political parties were able to present themselves as 'liberal' or 'conservative' and not as a hybrid, broad-church party. ACT targeted liberal voters in the main urban centres. New Zealand First and United Future both targeted conservative voters,

\footnotetext{
51 The Progressive Coalition and all non-parliamentary parties are excluded. Party size indicates ideological range, not vote share.
} 
although through different means. National, as a hybrid party, had to react to these new parties without turning other voters away. As Figure 4.5 shows, National has little room to move as other parties crowded around it. If National had reacted to a challenge by ACT with liberal policy, then they might have caused conservative voters to move to New Zealand First or United Future. Likewise, a reaction to New Zealand First or United Future policy may have caused liberal voters to move towards ACT.

The decentralised organisation prevented National from putting forward a cohesive statement under MMP of its policies and core beliefs. National produced 'muddled' policy which was largely a result of being unable to successfully find common policy between two different factions. A more centralised organisation would have been able to limit the factional tension within the extra-parliamentary party and perhaps would have provided more popular and populist policy stances.

\section{$\underline{\text { Reviews of Organisation }}$}

Party organisations can serve as an easy scapegoat for electoral failure. However, it appears that in the case of National during the transition to MMP that the organisational structure was one of the main reasons for electoral decline and not other factors which arose during the same period. The decentralised candidate selection process made the list candidate pools unappealing nationwide. The campaign structure gave too much control to electorates who, given the incentive to secure one's own election, did not push the party vote message. The ideological factionalism, which was reinforced by the decentralised organisation, made it hard for National to create consistent messages and policies. Therefore an effective response to such a decline would be to re-organise the Party in order to deal with the candidate selection, campaigning and factional 
issues. Two reviews were undertaken in the first ten years of MMP. The first review in 1997 attempted to centralise the organisational structure, but failed due to resistance. The second review, completed in 2003, again attempted to centralise the organisational structure, and succeeded in doing so.

\section{Review and Minor Re-Organisation}

While the Party undertook some candidate selection rule changes in 1995, it was decided to put off any significant review of the organisation until after the 1996 election. The 1997 review proposed many significant changes, yet these proposals were diluted and little actual change was achieved. This was because in 1997 "the Party was not licking the wounds of defeat", ${ }^{52}$ and did not feel the need for substantial internal reform. The conservative nature of organisation prevented significant change. National undertook the 1997 review so as to ask itself:

Proportional representation tends to reward smaller parties at the expense of larger ones. The electoral market-place will be more crowded from now. The main reason for a review flows directly from the move to MMP: Are we in a position to continue attracting membership, and support, in a more crowded field?

For 50 years we were the only centre-right party in New Zealand and there was no real alternative. MMP has delivered more choices to voters. ${ }^{53}$

The review was chaired by former Leader Jim McLay and included President Geoff Thompson as well as representatives of both the caucus and organisation.

\footnotetext{
${ }^{52}$ Clark, "The Impact of MMP on Political Party Electorate Organisations", 110.

${ }^{53}$ Emphasis in original. New Zealand National Party Review Committee quoted in Clark, "The Impact of MMP on Political Party Electorate Organisations", 111.
} 
The first discussion paper provided several potential options for re-forming the Party. The most radical suggestion was that National adopt a 'flat model' organisation. The divisions were to be removed and replaced with regional directors. This was quickly revised. Instead the reviewers looked at changing the number of divisions - with three or six divisions being favoured. Divisional flexibility was also discussed, with a proposal to reverse the decision of the $1984 / 5$ review in standardising divisional structure.

Furthermore, the review committee looked at the role of the National Executive and the Finance Committee. While formal power had been invested with the National Executive, the Finance Committee had been making most decisions on administration matters. The proposals put forward included replacing the Finance Committee with a National Management Committee, which would be a sub-committee of the National Executive. However, the final proposal recommended concentrating power by replacing the National Executive with the National Management Board and having the Finance Committee as a sub-committee. The proposed National Management Board would be smaller than the National Executive. There would be fewer divisional council representatives and the Treasurer would no longer be a member.

Consideration was given to establishing a new vice president who would be in charge of campaign strategy for the party vote. One of the failures of the 1996 campaign had been that National had assumed that the electorate vote would be considered as the primary vote by electors and that ticket-splitting would be minimal. However, both of these turned out to be false. By establishing a new executive position solely dedicated 
to the party vote, National would have at least one vice president who looked at the wider picture and who would be personally accountable if there was a decline in the party vote. However, the final review only recommended that "future consideration be given to the establishment of an additional vice presidential position to oversee Party Vote activity and the Campaign Planning Committee." ${ }^{, 54}$

Attention was also given to the role special interest groups played within the Party. There was some objection to the continuation of the Māori, women and youth special sections, although these objections were largely ignored. The procedure for nomination of the Māori Vice President was reviewed and a decision was made to hold a nationwide Hui instead of rotating the nomination between the divisions. Furthermore, the review recommended the establishment of a Youth Vice President, which would give the three nationwide social groups the same internal constitutional position as all three would have vice presidencies.

Some of the aforementioned proposals were adopted by the constitutional conference, while others were not. The resistance predominately came from divisional elites. ${ }^{55}$ The divisions were restored their organisational flexibility and the flat model was not adopted, nor was the number of divisions changed. In large, the party structure was unchanged and National remained a significantly decentralised political party. There were some minor changes at the top - yet these did little to re-organise the Party more appropriately for MMP.

\footnotetext{
${ }^{54}$ New Zealand National Party Review Committee quoted in: Clark, "The Impact of MMP on Political Party Electorate Organisations", 121.

${ }^{55}$ Clark, "The Impact of MMP on Political Party Electorate Organisations", 113-114.
} 
The National Executive was renamed the National Management Board denoting the business-model language of the Party and in some ways replicating the movement of managerial theories into the state sector. The new National Management Board was largely similar to the National Executive. Divisional representation was cut by five (one from each division), caucus lost a representative and the National Treasurer disappeared. The Māori Vice President's selection was changed so that the person was now selected at a Hui. The Young Nationals received a Youth Vice President, who was to be selected in a similar fashion to the Women's Vice President. ${ }^{56}$ However, overall the basic structure stayed largely unchanged and ten of the seventeen members were still directly elected by the divisions (see Appendix One).

The 1997 review proposed much, but achieved little. While the central elites sought greater control, the divisional elites were not willing to give up their power and could effectively resist change. The National Party was still in government at the time, and the full impact of MMP was yet to be felt or understood. Furthermore, National had only declined 1.3 percent since the previous election in 1993. The motivation to change a still successful organisational structure was lacking within the Party. Some minor changes were implemented, but these did little to address the dynamic new electoral environment in which National was now operating under.

\section{Review and Centralisation}

The 2002 election represented the nadir of National's support, and indeed post-war support for either of the two main political parties. The defeat left National deflated

\footnotetext{
${ }^{56}$ Consequently, Young National representation on the List Standing Committee went to the Youth Vice President.
} 
and showing signs of being in serious trouble. Blame was quickly placed on Party President Michelle Boag, who soon resigned her position. Two reviews were undertaken to evaluate the reasons for the electoral defeat.

The first review conducted by National sought to establish where blame lay for the electoral defeat. Many aspects of National's campaign went wrong. The funding was a shambles - in order to remain solvent National had to spend 30 percent of its fundraising money on repaying debts. Leader Bill English was inexperienced in his new role. Furthermore, the Party lacked a cohesive strategy and 'forgot' to explicitly campaign for the party vote. The 2002 election review committee recommended that a substantial review of the organisational structure be carried out. ${ }^{57}$

The organisation review was formally carried out by Steven Joyce (Radioworks CEO), Denese Henare (former Law Commissioner and wife of National MP Wayne Mapp) and Jeff Grant (MP 1987-1993, campaign director in 1999, businessman and farmer). Leader Bill English was heavily consulted throughout the process and was considered to be part of the team. ${ }^{58}$ The team consulted widely throughout the membership - the review team went on "little road shows around the various electorates.... [and visited] a lot of meetings at regional conferences and regional meetings."59

The review team looked beyond traditional political party organisation models in developing the potential new organisation structure. National looked towards

\footnotetext{
${ }^{57}$ The review of the 2002 election has never formally been made public. However, a leaked executive summary was read in the House by a Labour Cabinet Minister, see: Lianne Dalziel, "General Debate Speech, 11 September 2002," in Hansard (New Zealand House of Representatives, 2002).

${ }^{58}$ Subject B, Interview.

${ }^{59}$ Subject A, Interview with Gregory R. Stephens, 15 June 2007.
} 
commercial operations, producer boards, voluntary associations such as Federated Farmers, non-commercial organisations such as the New Zealand Rugby Union, charities and local government. ${ }^{60}$ The corporation board model was strongly considered with Steven Joyce arguing that he wanted "the National Management Board to become a more traditional [i.e. corporate] Board of Directors.",61

A substantial re-organisation of the Party was recommended by the review team to make the Party organisation work effectively in the MMP environment. The divisions were to lose much of their power and become known as 'regions'. The National Management Board was to be significantly downsized, with just seven extraparliamentary members all elected by the Annual Conference and two from caucus (including the leader). The President was to be elected by, and from within, the Board rather than by the Annual Conference. Three elected Board members would resign each year. The Māori and women sectors would be completely removed while the youth sector was still to get special recognition at the regional level; however, internal policy advisory groups could be established, but would not play a role in governing the Party. In candidate selection there was to be a candidate training college to professionalise candidate selection, and the electorate and list candidate nominations were to become largely carbon copies of each other through enforcing dual candidacy. Campaign decisions and strategy were to be brought into the centre. A minimum membership fee was to be introduced. The review team also recommended restoring loyalty to the monarchy as a guiding principle of the Party as part of the review.

\footnotetext{
${ }^{60}$ Subject B, Interview; Subject A, Interview.

${ }^{61}$ Quoted in: New Zealand National Party, "Nats to consider critical changes," (Scoop Press Release Archive, 2003).
} 
The 2003 review went to a special Constitutional Conference held on 12 April 2003 in Wellington. The conference had the same delegation rules as a normal annual conference. $^{62}$ A number of National elites gave speeches urging delegates to support the proposed changes. For instance, Leader Bill English stated:

We the National Party need to change our constitution and today is the day to do it. And there's a simple reason why we need to change our constitution. So that we can win. You all remember, I hope, as powerfully as I do the aftermath of the last election. And when I spoke with members of the National Party, then with supporters, when we sent the caucus out to talk to you about that defeat, there was a strong will to change. Now the pain might have receded, but the need to change has not. We have a simple requirement for the next election, that is to run a tightly focussed disciplined National Party campaign for the party vote. Because we've discovered without one of those, without that sort of campaign, MMP is absolutely unforgiving. ${ }^{63}$

President Judy Kirk noted:

We want to put in place an organisation that will allow the National Party to win the next election and we want to take our membership along with us. ${ }^{64}$

Review co-ordinator Steven Joyce argued that:

The structural revamp will give National room to grow and flourish in an MMP environment. It puts a definite focus on winning the Party vote and sends a message to

\footnotetext{
${ }^{62}$ For the delegate rules, see: New Zealand National Party, "Constitution and Rules of the New Zealand National Party," (Wellington: 1998), 14-15.

${ }^{63}$ Quoted in: New Zealand National Party, "English Speech: Give MPs the tools to do their job," (Scoop Press Release Archive, 2003).

${ }^{64}$ Quoted in: New Zealand National Party, "National Party overwhelmingly backs change," (Scoop Press Release Archive, 2003).
} 
the membership that it's serious about the business of being elected. ${ }^{65}$

Respected former Party President Sir George Chapman spoke behind closed doors and also urged delegates to vote for the constitutional amendments. ${ }^{66}$ The Party hierarchy was strongly pushing for change and clearly linked that they believe that MMP was the reason they needed to reform the organisational structure.

The vast majority of the amendments proposed in 2003 were adopted, including all those listed above, and the organisation was significantly altered (see Appendix One). Indeed what was seen prior to the conference as the most controversial change, the appointment of the President by the Board, was passed with near unanimity. ${ }^{67}$ The National Party undertook its largest re-organisation since 1936 with little opposition, little fanfare, but with significant impact both within the Party and ultimately outside the Party. The institutional inertia and conservative nature of organisation was broken with the 2002 election result.

\section{Decline and Re-Organisation}

National's decline under MMP took the Party by surprise. As with any waning of support there are many plausible explanations and indeed many of these do play some role in National's decline. However the change of electoral system meant that an organisation, which could have handled many of the problems National had faced in the 1990s, could not address the new challenges presented by MMP. The organisation was

\footnotetext{
${ }^{65}$ Quoted in: New Zealand National Party, "National Party overwhelmingly backs change."

${ }^{66}$ Subject B, Interview.

${ }^{67}$ Subject A, Interview.
} 
set up to campaign in a single-member simple-plurality electoral system environment not in a two-tiered proportional electoral system.

Other than implementing a list candidate selection method, National made minimal changes to prepare for MMP. The 1997 review did little to make the organisation more appropriate for MMP even though some change was made. It was not until the considerable defeat at the 2002 election that National realised that something needed to be done. The 2003 re-organisation substantially centralised the Party.

To test whether the centralisation did have impact on party behaviour, by influencing the power relations within National, two case studies will be analysed. The key areas of a political party's operation within a democracy are of candidate selection and campaigning. If the centralisation process worked, then these two aspects should show significant changes to how they previously operated and hence have different external outcomes. The power relations between central and regional elites will thus have shifted. If there is little sign of change both externally and internally, then the centralisation may have purely had an administrative effect and not truly impacted upon the balance of power within National. 


\section{Chapter Five: Candidate Selection}

Candidate selection is one of the key operations that political parties undertake in a democratic system. The decision on who is, and is not, a candidate determines the public face of the party. Changing candidate selection rules affects the nature of the candidates selected and therefore the image of whom the public see as the party. Furthermore:

The quality of candidates selected determines the quality of deputies [MPs] elected, of the resultant parliament, often of the members of the government and, to some extent, of a country's politics. A change in parties' selection procedures in any given country might thus have direct consequences for the way politics operate there. $^{1}$

Hence candidate selection not only plays an important role within a party, but also within a polity.

Within parties candidate selection provides an insight into intra-party conflict and power bases. Successfully selected candidates have won an internal battle whereas those who are not selected or are in un-winnable positions (low on the list or standing in an opposition stronghold) have seemingly lost the battle. The outcomes of candidate selection battles provide external evidence as to what happened within the 'secret garden' of politics.

\footnotetext{
${ }^{1}$ Michael Gallagher, "Introduction," in Michael Gallagher and Michael Marsh (eds.), Candidate Selection in Comparative Perspective: The Secret Garden of Politics, (London: Sage, 1988), 1.
} 
National's candidate selection method has traditionally been highly decentralised. The central authority (in its various guises) has had little say over who is the candidate as "the local electorates jealously protect their right to have the final say and heavyhanded pressure from the centre may backfire". ${ }^{2}$ With the introduction of MMP there was clearly a need to create a nationwide list selection process, yet the traditional power within National lay in discrete geographical units.

MMP, as a two-tiered electoral system, requires two different candidate pools. The electorate tier, using plurality rules, requires candidates which can appeal to the plurality of voters in a discrete area; while the list pool requires candidates which can appeal across the country. Given that it is the party vote which determines the overall composition of Parliament, nominations and selections should be aimed at providing list candidates which appeal across the nation. Hence candidate nomination and selection should be centralised.

\section{6, 1999 and 2002 Candidate Selection Outcomes}

The 1996, 1999 and 2002 elections all used the same candidate selection methods, although there was a minor change in 1997 with the youth representative on the selectorate being replaced by the new Youth Vice President. The list process was run parallel to the electorate candidate selection process. It was possible that the two candidate pools would not have any candidate overlap.

\footnotetext{
${ }^{2}$ Richard Mulgan, Politics in New Zealand, second ed. (Auckland: Auckland University Press, 1997), 255-256
} 
The electorate selection was not changed with the introduction of the list, and still remained in the hands of the electorate. Nomination was by ten party members. The electorate candidate selectorate was in the hands of each electorate's Selection Committee, with one delegate for every 15 members of a branch. Each electorate used progressive elimination voting until one candidate had a majority.

The introduced list process decentralised nominations and, while it was a nationwide process, there was significant divisional representation on the List Standing Committee. The list selection process required nominations from electorates and divisional councils, and each division ranked its candidates in a Divisional List Selection Meeting. The nationwide list was then ranked by the List Standing Committee. The two processes and selectorates did not overlap (see Appendix One).

All three elections produced similar outcomes in terms of what profile of candidate was selected. There were a substantial number of candidates standing for the list or for the electorate only. The National Party can be characterised during this period as having few ethnic minority or female candidates. There were also consistent geographical traits in the placement of list candidates.

National had five divisions. These divisions each had their own characteristics, as previously noted. Auckland (renamed Northern before the 1999 election) and Wellington (renamed Lower North Island before the 2002 election) were the liberal divisions. While Canterbury-Westland, Waikato (renamed Central North Island before the 1999 election) and Otago-Southland (renamed Southern before the 1999 election) 
were the conservative divisions. With the factions and divisions overlapping, the geographic traits also led into factional traits within the candidate pools.

Table 5.1 1996 National Candidate Pool ${ }^{3}$

\begin{tabular}{|c|c|c|c|c|c|c|c|c|c|c|}
\hline List Position Block & $\frac{\bar{Z}}{\frac{\vec{U}}{\frac{V}{0}}}$ & $\begin{array}{l}\frac{0}{\pi} \\
\frac{\pi}{\pi} \\
3 \\
3\end{array}$ & 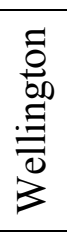 & 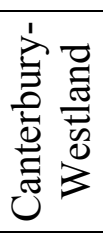 & 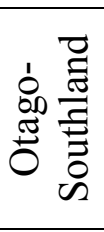 & 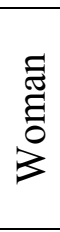 & $\begin{array}{l}\overline{0} \\
\sum_{0}^{\circ}\end{array}$ & 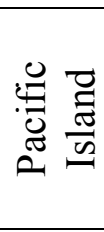 & $\cdot \frac{\bar{\pi}}{\frac{\pi}{2}}$ & 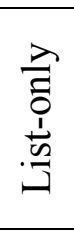 \\
\hline $1-10$ & 4 & 4 & 0 & 1 & 1 & 3 & 2 & 0 & 0 & 4 \\
\hline $11-20$ & 4 & 1 & 3 & 2 & 0 & 2 & 0 & 1 & 0 & 2 \\
\hline $21-30$ & 4 & 2 & 2 & 1 & 1 & 3 & 0 & 0 & 1 & 2 \\
\hline $31-40$ & 4 & 2 & 2 & 0 & 2 & 1 & 1 & 0 & 0 & 1 \\
\hline $41-50$ & 3 & 3 & 2 & 2 & 0 & 1 & 0 & 0 & 0 & 1 \\
\hline $51-60$ & 3 & 2 & 1 & 2 & 2 & 2 & 2 & 0 & 0 & 1 \\
\hline $61-65$ & 1 & 0 & 2 & 2 & 0 & 2 & 1 & 0 & 1 & 0 \\
\hline Electorate-only & 3 & 5 & 1 & 1 & 1 & 1 & 2 & 0 & 0 & - \\
\hline
\end{tabular}

In 1996 National stood 76 candidates overall. Of the top ten positions on the list, Auckland and Waikato were heavily represented, while Wellington was not represented at all. The strong bias towards Auckland continued throughout the list due to its population and electorate seat dominance within New Zealand. Seven women were in the top 30 (less than one quarter) and no woman further down the list was able to win an electorate. Māori were generally poorly represented, although there were two Māori candidates in the top ten. Overall the list was biased towards incumbent MPs - only one non-MP was in the top ten (Georgina Te Heuheu) and the next two new candidates were numbers 18 (Belinda Vernon) and 19 (Arthur Anae). No candidate was stood on Ohariu-Belmont due to a deal made with United Leader Peter Dunne. Eight of the top 30 on the list did not contest an electorate, although only one (Annabel Young at number 28) did not win a list seat on election night. Eleven candidates stood for an

\footnotetext{
${ }^{3}$ No divisional origin was released with the candidate list. Consequently the division each candidate is from has been calculated by electorate stood in, or for list-only candidates from previous or future electorates.
} 
electorate but not on the list with five being from the Waikato Division - only two were successful (Max Bradford in Rotorua and Murray McLean in Coromandel) (see Table 5.1 and Appendix Two).

Table 5.2 1999 National Candidate Pool ${ }^{4}$

\begin{tabular}{|c|c|c|c|c|c|c|c|c|c|c|}
\hline List Position Block & $\begin{array}{l}\frac{E}{0} \\
\frac{0}{0} \\
\text { Z }\end{array}$ & 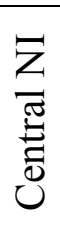 & $\begin{array}{l}\overline{0} \\
\stackrel{0}{00} \\
. \Xi \\
\overline{\overline{0}} \\
3\end{array}$ & 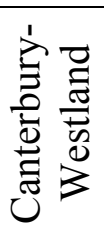 & 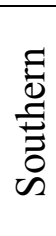 & 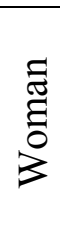 & $\begin{array}{l}\overline{0} \\
\sum_{\Sigma}^{10}\end{array}$ & 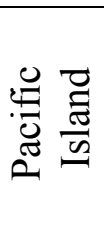 & $\frac{\pi}{\frac{\pi}{n}}$ & 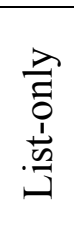 \\
\hline $1-10$ & 3 & 2 & 2 & 2 & 1 & 3 & 1 & 0 & 0 & 3 \\
\hline $11-20$ & 2 & 3 & 2 & 2 & 1 & 3 & 0 & 0 & 1 & 5 \\
\hline $21-30$ & 3 & 2 & 2 & 2 & 1 & 4 & 0 & 1 & 0 & 3 \\
\hline $31-40$ & 4 & 2 & 2 & 1 & 1 & 0 & 1 & 0 & 0 & 0 \\
\hline $41-50$ & 3 & 2 & 3 & 2 & 0 & 0 & 2 & 1 & 0 & 1 \\
\hline $51-60$ & 3 & 2 & 3 & 1 & 1 & 2 & 1 & 0 & 1 & 4 \\
\hline $61-65$ & 3 & 0 & 1 & 1 & 0 & 3 & 0 & 0 & 0 & 2 \\
\hline Electorate-only & 6 & 6 & 2 & 3 & 1 & 3 & 2 & 0 & 0 & - \\
\hline
\end{tabular}

The 1999 candidate pool followed a similar trend to that of the 1996 election. The geographical spread of the top ten positions on the list was greater - Northern (Auckland) had three, while Central North Island (Waikato), Wellington and Canterbury-Westland each had two, Southern (Otago-Southland) had only one candidate. Women were better represented with ten being in the top 30 . However Māori were worse off on National's list in 1999. Again no candidate was stood in Ohariu-Belmont to accommodate Peter Dunne and the Party decided to support ACT Leader Richard Prebble in Wellington Central by not standing a candidate against him. The number of list-only candidates in the top 30 increased to eleven. Furthermore, sixteen candidates stood in an electorate but not on the list; again Central North Island

\footnotetext{
${ }^{4}$ The division each list candidate was from was released in: New Zealand National Party, "National Announces Party List," (Scoop Press Release Archive, 1999).
} 
was significantly over-represented. The total candidate pool was 83 strong (see Table 5.2 and Appendix Two). ${ }^{5}$

Table 5.3 2002 National Candidate Pool ${ }^{6}$

\begin{tabular}{|c|c|c|c|c|c|c|c|c|c|c|}
\hline List Position Block & 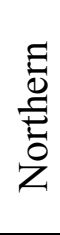 & 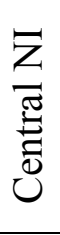 & $\begin{array}{l}\bar{Z} \\
\overline{0} \\
\vdots \\
0 \\
.\end{array}$ & 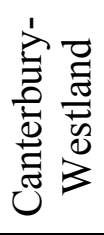 & 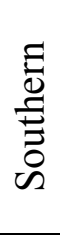 & 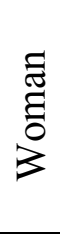 & 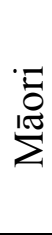 & 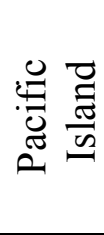 & $\frac{\pi}{\frac{\pi}{n}}$ & 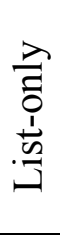 \\
\hline $1-10$ & 3 & 2 & 1 & 3 & 1 & 2 & 1 & 0 & 1 & 2 \\
\hline $11-20$ & 2 & 1 & 3 & 2 & 2 & 4 & 1 & 0 & 0 & 2 \\
\hline $21-30$ & 5 & 1 & 2 & 1 & 1 & 2 & 1 & 1 & 0 & 0 \\
\hline $31-40$ & 4 & 2 & 2 & 1 & 1 & 4 & 1 & 0 & 1 & 2 \\
\hline $41-50$ & 4 & 1 & 4 & 1 & 0 & 3 & 1 & 0 & 0 & 0 \\
\hline $51-60$ & 5 & 2 & 0 & 2 & 1 & 2 & 2 & 1 & 0 & 1 \\
\hline $61-65$ & 1 & 3 & 0 & 1 & 0 & 0 & 1 & 0 & 0 & 3 \\
\hline Electorate-only & 3 & 6 & 2 & 3 & 0 & 0 & 2 & 0 & 0 & - \\
\hline
\end{tabular}

The 2002 election again repeated the dominance of Northern in the list, with one-third of the top 30 positions on the list being Northern candidates. While the Lower North Island (Wellington) Division succeeded in securing some high places for their candidates, they were told by other divisions that they could not have any significant representation until further down the list even though they had a high number of quality candidates. ${ }^{7}$ Māori were more strongly represented throughout the list with one candidate per block of ten. Pansy Wong's promotion on the list saw an Asian in the top ten for the first time. Female representation fell to just eight in the top 30. The number of list-only candidates fell, while there were fourteen electorate-only candidates and again Central North Island was over-represented. There was an attempt at significant

\footnotetext{
${ }^{5}$ Initially the 1999 list had 65 candidates, however the Electoral Commission received a list of 64 candidates indicating that Rea Wikaira had withdrawn at some stage - the analysis made here is with Wikaira as that more accurately reflects the internal dynamics within the List Standing Committee.

${ }^{6}$ These figures differ from those used by Salmond, "Choosing Candidates," 200. Instead the divisional origin relies on: New Zealand National Party, "General Election 2002- National Party List Ranking," Scoop, http://www.scoop.co.nz/stories/PA0206/S00251.htm, 2002 (accessed: 7 November 2007).

${ }^{7}$ Salmond, "Choosing Candidates," 201.
} 
renewal with four new candidates in the 11-20 block - although none entered Parliament due to the poor election result. Further attempts at renewal were found in a number of electorates. Party President Michelle Boag was able to use her considerable influence to ensure Hekia Parata and John Key were selected, but Boag failed in her attempt to unseat Clem Simich. ${ }^{8}$ For the first time under MMP a candidate was put up in each electorate - the Party decided to challenge Peter Dunne in Ohariu-Belmont and Richard Prebble had failed to hold Wellington Central in 1999 (see Table 5.3 and Appendix Two).

The 1996, 1999 and 2002 candidate pools had striking similarities, differences and trends. Northern/Auckland's dominance of the higher list placements fell. Central North Island/Waikato electorate candidates were the least likely to stand on the list indicating that they realised that the regional list quota was not influenced by the number of electorate-only candidates and that they could thus have a higher number of candidates than proportionality would allow. Identity candidates were underrepresented as fourteen percent of candidates were Māori, Asian or Pacific Islanders and 21 percent were female. There were no openly homosexual candidates. Māori fared best in 2002 and women in 1999. The number of list-only candidates peaked in 1999 at over one quarter of the entire list. Only in 2002 did National stand a candidate in each electorate, indicating that the Executive (in 1996) or the Board (in 1999) was able to prevent electorates from undertaking candidate selection procedures for strategic reasons.

\footnotetext{
${ }^{8}$ Salmond, "Choosing Candidates," 198-199.
} 


\section{Changes}

The 2003 review created a significant change in National's candidate selection process, even though formally it looked as though little change was put through. The National Management Board gained power and control in determining who will be, and who will not be, a candidate even though formally more power went to the electorates. The major changes were the introduction of a candidate training college, making the electorate candidate process effectively the nomination process for the list and thus enforcing dual candidacy, and changing the composition of the list selectorate (alongside its name).

\section{Candidate's Club}

The objective of the Candidate's Club (sic) ${ }^{9}$ was to ensure that the candidates selected for electorates were capable of winning those seats. The Club aimed to professionalise and improve the quality of candidates within the National Party by training potential candidates. While personal candidate voting has not been strong in New Zealand, ${ }^{10}$ local candidates are one of the many faces of their party presented to the public. National was not only in decline regarding the party vote but was also losing electorate seats under MMP - National won 30 out of 65 seats in 1996, 22 out of 67 in 1999 and 21 out of 69 in 2002.

Enrolees for the Candidate's Club are chosen by the National Management Board by whatever means the Board decides. The Party's Constitution and Rules states that the

\footnotetext{
${ }^{9}$ The National Constitution and Rules refers to it as the "Candidate's Club", while it should be known as the "Candidates' Club".

${ }^{10}$ Bean, "Party Leaders and Local Candidates," 154.
} 
Club provides enrolees with "policy information... training arrangements and other opportunities to gain skill and knowledge to enhance their preparation for selection." 11 Those under the training of the Club are able to seek selection in any electorate that they chose, and are to be automatically considered an 'approved candidate' and thus not needing ten local members to nominate them. The Board can therefore effectively nominate candidates for electorates. Any member of the Candidate's Club is unlikely to encounter any problems at the Pre-selection Committee as the President appoints two of the nine members. After the Pre-selection Committee the nominees then undertake an array of Meet the Candidates Meetings - where the policy information and training of the Club nominee is likely to come through. Delegates to the electorate's Selection Committee are more likely to vote for a Candidate's Club nominee given their training, expertise and the (at least implied) backing of the Board.

The Candidate's Club, while formally ensuring a better quality of candidate, significantly alters the electorates' control over candidate selection. The Board's ability to ensure that certain candidates are selected increases significantly, when compared to the 2002 selection wrangles, ${ }^{12}$ due to the increased likelihood of Club candidates being selected. National could thus expect more 'outsiders' (not longserving party members) to become electorate candidates, as well as more women, ethnic minorities and other identity representatives. Furthermore, the electorates may no longer select highly factional candidates with compromise candidates more likely to be pushed by the Board. However, the Board's selection control is by no means perfect

\footnotetext{
${ }^{11}$ New Zealand National Party, "Constitution and Rules of the New Zealand National Party," (Wellington: 2003), 42.

${ }^{12}$ See: Salmond, "Choosing Candidates," 199.
} 
and National's electorate candidate selection remains more decentralised than Labour's selection process which has substantial central representation on the selectorate. ${ }^{13}$

Another significant advantage of the Club is that it gives the senior leadership the ability to interact with candidates. Consequently, they are able to "get a pretty good idea [of] who the potential stars are et cetera, and who aren't." ${ }^{\prime 14}$ Thus when the list is ranked several members of the List Ranking Committee (see below) will have personally met the candidates and thus have assessed the quality of the candidates rather than simply relying upon each candidate's curriculum vitae and reputation. The list ranking of new candidates should therefore be a better reflection of skill and quality than of regional tallying.

\section{$\underline{\text { List Nomination Process }}$}

Previously each electorate selected two potential list candidates and each Divisional Council selected one potential list candidate per electorate. ${ }^{15}$ At the electorate level a similar process in selecting an electorate candidate was used, with some slight modifications to elect two nominees. The divisional nominee was selected through preferential voting by the Divisional Council. ${ }^{16}$ The Divisional List Selection Meeting would then rank the division's candidates and limit the number of candidates to that

\footnotetext{
${ }^{13}$ For Labour see: New Zealand Labour Party, "New Zealand Labour Party Constitution and Rules," (Wellington: 2007), 19. Also see: Miller, Party Politics in New Zealand, 113.

${ }^{14}$ Subject C, Interview with Gregory R. Stephens, 12 November 2007.

${ }^{15}$ If an electorate did not nominate two candidates then the Divisional Council could nominate an extra candidate instead.

${ }^{16}$ The Divisional Council is predominately made up of the electorate chairs, divisional chairs from the youth, Māori and women's sections, and divisional conference elected representatives (including the chairperson) (see Appendix One).
} 
pre-determined by the Board on the basis of population. The 2003 changes considerably altered that process.

The 2003 changes mean that all electorate candidates are able to nominate themselves for the list, without being filtered by electorates or divisions, and all electorate candidates "will be strongly encouraged by the Board to be also nominated for the Party list". ${ }^{17}$ These dual candidates are then ranked by the Regional List Ranking Forum (equivalent to the Regional Conference) for the region their electorate falls within. The National Management Board may, at its discretion, nominate up to five candidates for the list who are not electorate candidates, giving the Board more control. Regional elites have no role in nominating list candidates. All list nominees are then ranked by the nationwide List Ranking Committee.

Effectively, this single pool of dual candidates provides a better guarantee that all candidates will seek both the party and electorate votes during an election campaign. In previous MMP campaigns a number of electorate candidates did not fight for the party vote. Furthermore, list candidates with no set electorate could have struggled to campaign meaningfully for National and, in effect, entered Parliament on the hard campaign work of other candidates. By making the electorate candidate pool subservient to the list candidate pool, National could expect a better electorate campaign that focused on both votes.

Within National many of the ethnic and women MPs have come into Parliament through the list. Due to the electorate seeking 'someone like them' and not considering

\footnotetext{
${ }^{17}$ New Zealand National Party, "Constitution and Rules (2003)," 64.
} 
nationwide gender balance "historically women have found it difficult to gain nomination for National constituency candidature". ${ }^{18}$ Given the low number of Māori, Pacific Island or Asian candidates selected in electorates, ${ }^{19}$ a similar argument can be made that electorates did not consider nationwide ethnicity balance either. Hence there is a significant possibility that while electorate campaigning is improved; nationwide National has fewer women, Māori and other identity group representatives than in previous elections where they were already sparse.

\section{$\underline{\text { List Selectorate }}$}

The 2003 re-organisation affected the body which ranked the candidates. Previously the List Standing Committee was made up of the Leader, Deputy Leader, President, five divisional vice presidents, the youth, Māori and women's vice presidents and four representatives from each of the five divisions (see Appendix One). Due to the changes to the National Management Board composition some of these positions no longer existed after the 2003 review.

Instead, the List Ranking Committee was to be made up of the Leader, Deputy Leader, President, non-parliamentary Board members, and each of the five regions will be represented by the Regional Chairperson and three other representatives (see Appendix One). Notably there are no ex officio representatives for youth, Māori or women on the Committee. Furthermore, the regions each have fewer representatives, although they are still strongly represented. Previously divisional representatives held 25 (five each)

\footnotetext{
${ }^{18}$ McLeay, "Representation, Selection, Election," 299.

${ }^{19}$ Tables 5.1, 5.2 and 5.3 and Appendix Two. Also see: Miller, Party Politics in New Zealand, 203, 204205.
} 
of the 31 List Standing Committee seats, whereas regions only hold 20 (four each) of the 29 seats on the List Ranking Committee.

The changes to the List Ranking Committee increase the power of the National Management Board, and in particular the Leader, to determine the list rankings - not only do they have more representation, but they also have had greater interaction with all candidates due to the Candidate's Club. Instead of divisions fighting for list placements it becomes likely that no informal regional quota system will develop and that list ranking will be more determined by the quality of the candidate rather than where they are from. The removal of the Māori, women and youth representatives may cause the list to no longer have high-placed identity candidates - indeed this is furthered by the electorate selection being the list nomination, limiting the ability of the list to bring in identity candidates.

Together, these rule changes - the introduction of the Candidate's Club and the changes to the list nomination process and the list selectorate - created a substantially different candidate selection approach within National. Formally the candidate selection process became more decentralised - electorates controlled both their own candidate selection and nomination for the vast majority of the list. Yet potentially, the Board gained control over the candidate selection process through the Candidate's Club, the removal of divisionally nominated list candidates, and a greater voting presence on the List Ranking Committee.

The theoretical impact that the new candidate selection process has on the candidate outcomes is not necessarily clear. The Candidate's Club may produce more identity 
candidates within electorates. However, if this does not happen, then the requirement that all but five list candidates are electorate candidates means that there is little chance of the list being able to provide a balancing mechanism to ensure identity representation. The informal regional quota system operating within the List Ranking Committee should subside, meaning that there would be little semblance of regional order on National's list. The 2005 candidate selection process was the first to operate under the new rules.

\section{Candidate Selection}

National undertook candidate selection for the 2005 election in late-2004 and early2005. However, the Candidate's Club had been operating since early-2004. The new candidate selection process resulted in a different outcome from previous elections indicating a significant change in the power relations between the National Management Board, regions and electorates. While there was a change, the 2005 selection still gave regions considerable power - indicating that there may be a further attempt at centralisation in candidate selection by the central elites.

\section{Candidates' College}

The 2005 election was the first to run the Candidate's Club - although elites referred to it by the more professional and educational title of the 'Candidates' College'. While little information about the College was made publicly available, President Judy Kirk noted in early 2004 that:

Sixty four potential candidates have attended the

College.... At the moment, I cannot think of one major 
selection which will not be contested by a number of people, any one of whom would be a good candidate.... Strong and well prepared candidates are important in our plan.... I am very grateful to Don [Brash], the Caucus, previous leaders and MPs for their support and help with the college. ${ }^{20}$

The Candidates' College was up and running at least one year and four months before the election. With 64 club participants it would have been obvious from the outset that not all would be able to secure nomination, especially if none challenged a sitting MP. Steven Joyce, the 2005 campaign manager, noted that the College "directly led to the very strong set of well-prepared and disciplined candidates National was able to field in the 2005 election." 21 The College obviously provided significant mentoring to make sure each candidate understood their roles, obligations and followed the decisions of the Board and Leader.

National, as a rule, does not release the names of those in the College. ${ }^{22}$ It is known that there were a number of high profile individuals whom National attempted to woo to stand as a candidate. Leader Don Brash sought out "people who on the face are very good all-rounders, and some people who have real expertise in particular areas." ${ }^{, 23}$ There was speculation that high profile lawyer Judith Ablett-Kerr QC would stand, ${ }^{24}$

\footnotetext{
${ }^{20}$ Judy Kirk, "Address to National Party Lower North Island Regional Conference " New Zealand National Party, http://www.national.org.nz/Article.aspx?articleId=1966, 2004 (accessed: 6 November 2007).

${ }^{21}$ Emphasis added. Steven Joyce, "National - The Road to Recovery," in Stephen Levine and Nigel S. Roberts (eds.), The Baubles of Office: The New Zealand General Election of 2005, (Wellington: Victoria University Press, 2007), 107.

${ }^{22}$ New Zealand National Party, "Constitution and Rules (2003)," 42.

23 Quoted in: Helen Tunnah, "Wanted: new Brash-pack MPs," New Zealand Herald, http://www.nzherald.co.nz/section/1/story.cfm?c_id=1\&objectid=3577376, 2004 (accessed: 30 October 2007).

${ }^{24}$ Sarah Catherall, "National politics on the cards for QC Judith Ablett-Kerr," New Zealand Herald, http://www.nzherald.co.nz/organisation/story.cfm?o_id=500483\&objectid=10122111, 2005 (accessed: 9 November 2007).
} 
although she decided not to. Another potential candidate who did not stand was Business Roundtable chairman Rob McLeod. ${ }^{25}$ Speculation also existed around Wellington lawyer Chris Finlayson and Auckland principal Allan Peachey, ${ }^{26}$ both of whom ended up standing for National. It is likely that some of these candidates were involved within the Candidates' College thus creating such conjecture in the media.

A notable sign in the ability of the Candidates' College is evident in the number of electorates National managed to win in 2005. While National won a number of marginal seats from Labour, National also won some seats that it had not held in many years and were becoming seen as safe, or relatively safe, seats for other parties. Napier was held from 1981 to 1999 by Labour's Geoff Braybrooke - in 1999 he secured over 60 percent of the electorate vote - and it was taken over by Labour's Russell Fairbrother in 2002 with 45 percent of the electorate vote. In 2005 National presented a new candidate in Napier, Chris Tremain, who won just over half of the electorate votes. Bob Clarkson, another new candidate, was able to take Tauranga from New Zealand First Leader Winston Peters, who had held the seat since 1984. Craig Foss, in his second attempt, won Tukituki from Rick Barker, which had been a Labour stronghold under various guises. Chester Borrows, in his third attempt, won the Whanganui electorate from Jill Pettis who had won the seat in 1993 and had held it since then. These candidates were able to do in 2005 what various candidates had been unable to do for many years - win new electorate seats for National. Again, it is not possible to tell whether these candidates were College participants, but it is likely that a number of them were.

\footnotetext{
${ }^{25}$ Tunnah, "Wanted: new Brash-pack MPs,"

${ }^{26}$ Tunnah, "Wanted: new Brash-pack MPs,"
} 
In 2005 the College did not act as an effective filter as was expected. The Board allowed 64 nominees in. One interview subject noted that "[i]t's very easy to get into the Candidates' College. I don't know many who've been refused, but nutters have been [refused]". ${ }^{27}$ The College was not exclusive enough to ensure that candidates were guided to nomination in electorates. Furthermore, a number of electorates selected candidates that were not trained by the College. ${ }^{28}$ While the Board did gain some extra control, it was not what they necessarily expected. However, the Party expected a large crop of new MPs, due to the significant poll increase in 2004, and may have wanted to keep the potential candidate pool as wide as possible. The success of the College in training new candidates to win seats and votes means that it is likely to play a more prominent role in future elections.

\section{No Māori Seat Candidates}

National decided to not stand any candidates in the seven Māori seats as part of National's commitment to abolish the Māori seats in order to achieve its 'one law for all' policy stance. However, the decision could also have been made because National was unlikely to find suitable Māori candidates or have any real chance in picking up many votes in the Māori seats. National never won a Māori seat in the post-war era due to the Labour-Ratana alliance, and National was unlikely to do so in 2005. The Press political reporter Peter Luke speculated that National's decision was "a classic political

\footnotetext{
${ }^{27}$ Subject C, Interview.

${ }^{28}$ Subject C, Interview.
} 
instance of making a virtue out of a necessity" as "National's prospects in the Maori [sic] seats were remarkably dim." 29

A decision not to contest an electorate has significant consequences for any party. The spending limit falls by $\$ 20,000$ for each electorate that is not contested. At some public meetings there may be no party representative present, depending on the organiser's rules. There will be less publicity locally within the electorate. Voters may feel as though they are being ignored and hence become less likely to cast a party vote in favour of the party. National's decision not to stand a candidate in the seven Māori seats inevitably meant that their spending cap was $\$ 140,000$ less than that of other parties (including Labour) and that they were likely to lose party votes from those on the Māori roll. Furthermore, with the dual candidacy requirements, National was not going to have significant Māori representation on the list.

The choice to not stand any candidates in the Māori seats was made by the Board and caucus. Leader Don Brash stated that the "caucus agrees with a decision by the Party board that National will campaign only for the party vote in the Maori [sic] electorates." ${ }^{30}$ However, under the Constitution and Rules there is no role for the caucus to play in determining candidate selection processes - indicating that the centralisation may have also increased the control of the caucus over the extraparliamentary party. The Māori seats decision was made for policy reasons, yet under the Constitution and Rules the Board may only consider four matters when deciding not

\footnotetext{
${ }^{29}$ Peter Luke, "Nats shift stance on Maori seats," The Press, 27 November 2004.

30 Don Brash, "National opts for party vote only in Maori seats," New Zealand National Party, http://www.national.org.nz/Article.aspx?ArticleID=3217, 2004 (accessed: 13 November 2007).
} 
to allow a candidate selection process to occur - none of which deal with policy or strategic matters. $^{31}$

The decision by the Board not to allow candidates to stand in the Māori seats was partially a result of the 2003 centralisation. Previously such a decision could have been made but would have resulted in internal fighting as the Māori Vice President would have strongly resisted such a move. ${ }^{32}$ The liberal Auckland and Wellington divisions may have also provided resistance. The new Board (see Appendix One), with no social or regional representation, meant that there was little resistance or veto players to the decision within the Board itself.

\section{$\underline{\text { List Outcome }}$}

The National Party list in 2005 was different from that of previous MMP lists. The representation of ethnic minorities and women fell dramatically. The list position of all sitting MPs was determined by their caucus rankings and not by the extra-parliamentary party. The regional origin of candidates also seemed to matter less. Furthermore, no candidate stood solely in an electorate and only three candidates stood solely on the list.

The list and electorate pools were largely carbon copies of each other. The National Constitution and Rules only requires that electorate candidates be "strongly encouraged by the Board to be also nominated for the Party list." ${ }^{33}$ In 2005 President Judy Kirk

\footnotetext{
${ }^{31}$ See: New Zealand National Party, "Constitution and Rules (2003)," 43-44.

${ }^{32}$ Parallels can be found in debates over the removal of the Māori seats, see: Gustafson, The First 50 Years, 253.

${ }^{33}$ New Zealand National Party, "Constitution and Rules (2003)," 64.
} 
noted that "the constituent candidate is also the list nomination". ${ }^{34}$ For the first time all electorate candidates stood on the list, indicating that the encouragement given essentially made it a necessity to stand on the list. The Board has up to five nominations for list-only candidates; in 2005 they used three of these nominations Leader Don Brash, high-profile Māori MP Georgina Te Heuheu and new-comer Tim Groser. Apart from these three candidates, the two candidate pools were identical.

The number of ethnic minority and female candidates fell within National. National had only two Māori candidates - Georgina Te Heuheu (19) and Tau Henare (29). There was one Pacific Island candidate - Fepulea'i Ulua'ipou-O-Malo Aiono (47). National also had three Asian candidates - Pansy Wong (20), Ravi Musuku (48) and Ken Yee (58). All bar Te Heuheu stood in an electorate rather than being nominated for the list by the Board. The list was also poorly representative of women - there were only six women in the top thirty of the list (one-fifth) and eleven in the rest of the list (less than one-third). For the first time National had an openly homosexual candidate Chris Finlayson (27). Identity candidates fared very poorly in 2005 and National's list was not reflective of New Zealand society.

The changes to the candidate selection rules limited the ability of National to bring in ethnic and female candidates. Previously, women and ethnic minority candidates could be brought in through the list nomination process if none (or few) were selected to stand in electorates. The decision to have no candidates in the Māori electorates in 2005 meant that National did not automatically have seven Māori candidates on its list.

\footnotetext{
${ }^{34}$ Emphasis added. Quoted in: Ruth Berry, "All National candidates to be on list," New Zealand Herald, http://www.nzherald.co.nz/topic/story.cfm?c_id=467\&objectid=10127743, $2005 \quad$ (accessed: $\quad 15$ November 2007).
} 
Further, few ethnic minority or females were selected in general electorates, and the Board only nominated one female Māori for the list. While the changes to the candidate selection rules led to more party vote-focused electorate candidates, nationwide National was unrepresentative of New Zealand society and hence less likely to attract ethnic minority and female voters. However, the lack of social identity candidates worked in with National's overall strategy of defining itself as the anti‘political correctness' party (see Chapter Six).

One of the key outcomes of the 2005 list was that the top positions were a carbon copy of the caucus rankings of the re-standing MPs. The caucus was last ranked unilaterally by Leader Don Brash in August 2004, although there were some changes between then and the list being announced in May 2005 (notably the demotion of Katherine Rich and consequent promotion of John Key to the frontbench). The first discrepancy between the caucus rankings and the list rankings occurred at number 13 - with Tim Groser coming in to take that position. Apart from Groser, caucus rankings continued throughout the list. The next non-incumbent on National's list was Chris Finlayson at number 27 - below all MPs seeking re-election. The fact that all re-standing incumbent MPs were in order of caucus rankings reflected a change in who controlled the list selectorate.

National Party insider and former-parliamentary staffer David Farrar noted on his blog that "it was decided to exempt MPs from regional rankings and have them in the top 30 in their caucus order." 35 This decision is clearly an indication of centralisation and an

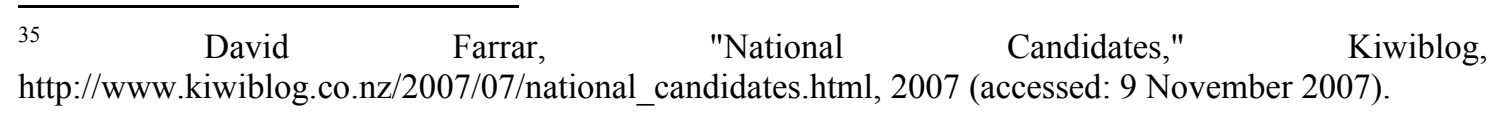


increase in the power of the Leader. As it is the Leader who decided upon caucus ranking, the continuation of those rankings onto the list means that the loyalty of MPs changed. Previously, errant MPs could claim that their legitimacy within the National caucus came from the extra-parliamentary party and not from the Leader. By allowing the Leader's ranking of caucus to determine the list ranking, the Leader was able to assume far greater control over MPs. Indeed it appears that the extra-parliamentary party will simply reinforce and agree with the decisions of the Leader, rather than serve as an external power base and as a court of appeal. The Leader's extra control came from his ability to influence the much-smaller Board and his significant role in choosing the President.

Table 5.4 2005 National Candidate Pool ${ }^{36}$

\begin{tabular}{|c|c|c|c|c|c|c|c|c|c|c|c|}
\hline List Position Block & 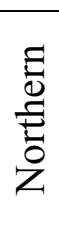 & 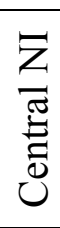 & $\begin{array}{l}\bar{Z} \\
\overline{0} \\
\dot{0} \\
0 \\
\end{array}$ & 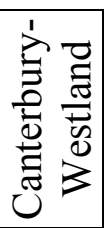 & 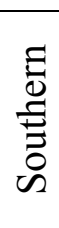 & 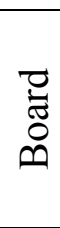 & 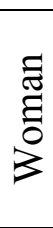 & 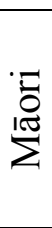 & 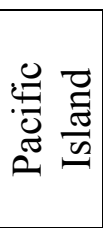 & $\cdot \frac{\bar{E}}{\frac{\pi}{2}}$ & 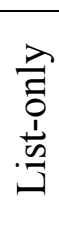 \\
\hline $1-10$ & 2 & 1 & 1 & 3 & 2 & 1 & 1 & 0 & 0 & 0 & 1 \\
\hline $11-20$ & 7 & 1 & 0 & 0 & 0 & 2 & 3 & 1 & 0 & 1 & 2 \\
\hline $21-30$ & 4 & 3 & 1 & 2 & 0 & 0 & 2 & 1 & 0 & 0 & 0 \\
\hline $31-40$ & 1 & 1 & 3 & 2 & 3 & 0 & 3 & 0 & 0 & 0 & 0 \\
\hline $41-50$ & 4 & 2 & 3 & 1 & 0 & 0 & 5 & 0 & 1 & 1 & 0 \\
\hline $51-60$ & 3 & 2 & 3 & 1 & 1 & 0 & 1 & 0 & 0 & 1 & 0 \\
\hline $61-65$ & 0 & 2 & 2 & 1 & 0 & 0 & 2 & 0 & 0 & 0 & 0 \\
\hline
\end{tabular}

The regional breakdown for the 2005 candidate pool is complicated by the fact that sitting MPs were excluded from the regional rankings and simply placed in caucus order. However, if regionalism still mattered then the List Ranking Committee should have provided substantial balance for regions that were poorly represented within caucus by ensuring high-placed list rankings for those regions. There would have been

\footnotetext{
${ }^{36}$ Regional origin was calculated by the electorate in which each candidate stood in.
} 
pressure by those regions poorly represented in caucus to provide regional balance as had happened at previous elections. ${ }^{37}$ Yet this did not happen. The Lower North Island only had one MP seeking re-election (Simon Power), ${ }^{38}$ and did receive the second non-incumbent spot (Chris Finlayson at 27). In the next block, the Lower North Island received three candidates at 33, 36 and 39. Canterbury-Westland had five MPs seeking re-election, with three being in the top ten. The third non-incumbent position (28) went to Nicky Wagner who stood in Christchurch Central. Positions 31, 38 and 42 then went to Canterbury-Westland candidates. The Lower North Island was not compensated for the lack of regional representation it had in the top positions when compared to Canterbury-Westland.

The different treatment of Lower North Island and Canterbury-Westland candidates indicates that in 2005 regionalism mattered less within the List Ranking Committee. Both Canterbury-Westland and the Lower North Island were important electoral grounds for National, although for different reasons, and should have been balanced. Repeating caucus rankings on the list meant that regional fighting for the top list positions was diluted and may have stopped regions from attempting to seriously fight for list rankings. Furthermore, as the senior leadership had more interaction with candidates, due to the Candidates' College, the quality of each candidate is likely to have had more of an impact on their list placement. The dilution of regionalism had a positive impact on the list as the quality of high-placed list candidates should be improved. However, regionalism was still important as it ensured that the Party

\footnotetext{
${ }^{37}$ For the 2002 balance experience, see: Salmond, "Choosing Candidates," 200-201.

${ }^{38}$ Roger Sowry was the only other Lower North Island MP in the caucus but had decided not to re-stand.
} 
adequately spread itself nationwide and maximised the attractiveness of National's list throughout the country.

The different nature of the candidate pool reflects both the changes made and decisions to use new opportunities arising from the rule changes. The pool was less reflective of society as a whole (see Table 5.4 and Appendix Two). Thus, the new rules did not work as well as they might have.

\section{Unfinished Business in Candidate Selection}

One of the key roles political parties play within a democracy is to select the candidates for whom electors vote. After the changes to National's candidate selection rules, National is arguably less democratic. The Candidate's Club gives the Board limited influence over the electorate selection and hence the list nomination process, although more than they have previously had. Furthermore, the regions have a decreased role in ranking list candidates.

Candidate selection is one of the areas to watch in future adjustments to National's organisation as it is a highly contested arena within the National Party itself. There was still institutional inertia in 2003 which prevented the complete centralisation of candidate selection. One interview subject stated that:

[In candidate selection there are] just some technical issues around making sure the representation is right and everything. Just more a case of clarifying the rules, there is some things that probably could have been made 
clearer. But I don't think any wholesale change [needs to be made]. ${ }^{39}$

But another interview subject thought otherwise:

Personally, I wish it [the Candidate's Club] would go more like the UK system where it would be a bit more elitist and get them, not quite like the Conservative AList, but a real sign that this person will be a good candidate and electorates [should be] strongly encouraged to take people who have been through Candidates' College cause it means they've been able to [have] been sussed out. $^{40}$

Candidate selection could become more centralised within National - Labour is still significantly more centralised. It is likely that the role of the Candidate's Club will become a more active filter in determining whether a candidate is selected or not as a means of increasing central control without amending the Constitution and Rules. Further adjustments may come in ensuring that ethnic minority and female candidates are able to get on to the list - especially given the diversifying ethnic makeup of New Zealand.

Nevertheless, the changes National undertook significantly altered what type of candidate was selected. The Candidate's Club resulted in a different form of political aspirant, although it did not act as a significant filter as theoretically expected or as it may do in the future. The decision to make all electorate candidates stand on the list altered the way electorate candidates acted within the campaign, but also limited the ability of the list to provide an ethnic and gender balance. The List Standing Committee, with less regional representation, limited the fighting between regions for

\footnotetext{
${ }^{39}$ Subject A, Interview.

${ }^{40}$ Subject C, Interview.
} 
list positions and suggests that for the National Party the quality of a candidate is now more important than regional quantity.

Further changes are likely to occur to in the candidate selection process in order to provide a better pool of candidates at each election. The National Management Board did gain significant control over the selection process, but not as much as some elites wished. Regions still have a significant say over candidate selection in National. However, the partial centralisation of National did result in a candidate pool more suitable to an MMP environment than that which the decentralised organisation could provide. 


\section{Chapter Six: Campaigning}

The organisational restructuring of 2003 significantly altered the way in which the National Party operated in the following 2005 general election. The Party was able to run its best campaign in several elections. The new organisational structure played a key role for National in helping attain 39.1 percent of the vote - almost double that of the 2002 election and beginning to get close to its FPP average of 44 percent.

The re-organisation affected National's campaigning in several different ways: party organisation creates and promotes some opportunities while preventing and limiting others. In the case of National, financial control became managed by the National Management Board, removing money from an internal power play between divisions, thus allowing significant corporate donations. With larger finances, as well as more central control of the campaign, the Party was able to hire external professionals to help with campaign strategy and advertising. The professionals introduced new strategies and some of these strategies required a flexible leadership-member relationship which the centralisation allowed. Further changes were to be found in advertising, with the centralised control giving National a clearer, more consistent nationwide messaging as well as enabling the Party to fully use the expertise of professionals. Thus, the centralisation process affected the way in which National campaigned and hence had a significant impact on the election result.

Other dynamics were at play in the 2005 election which means that the successful turnaround of National's results may not solely be ascribed to the centralisation within National. During the 2002-2005 parliamentary term many events occurred which may 
have contributed to National's vote share increasing. ${ }^{1}$ Don Brash replaced Bill English as Leader - even though significant doubts were raised about Brash's ability to lead the Party. $^{2}$ Brash's Orewa speech and the subsequent fallout resulted in a 17 percent poll rise for National and "restored a sense of contest and balance". ${ }^{3}$ National replaced Party President Michelle Boag with Judy Kirk, and brought in Steven Joyce as General Manager. Changes between the elections also occurred outside of National - Labour suffered some embarrassing scandals and promoted unpopular policy (such as school closures); the Exclusive Brethren decided to become involved in 'worldly' politics; ACT replaced Leader Richard Prebble with Rodney Hide; and the foreshore and seabed controversy created significant Māori political change, ultimately leading to the development of the new Māori Party. These other internal and external factors provide non-organisational explanations as to why National was able to rebuild its vote share. However, the re-organisation provided a backbone on which these other factors could rebuild National's vote share in the 2005 campaign.

\section{Decentralised Campaigning in an MMP Environment}

National's 1996, 1999 and 2002 campaign all have similar facets to them. During these three election campaigns National did not run MMP campaigns, but rather the decentralised organisation ran different campaigns throughout the country. As one interview subject noted:

\footnotetext{
${ }^{1}$ See: Brett de Malmanche, "Appendix 8: 'Events, My Dear Boy': The Political Scene, 2002-2005," in Stephen Levine and Nigel S. Roberts (eds.), The Baubles of Office: The New Zealand General Election of 2005, (Wellington: Victoria University Press, 2007).

${ }_{2}^{2}$ For instance, see: Dedire Mussen, "Brash challenge is 'laying groundwork for National defeat in 2008 election'," Sunday Star Times, 26 October 2003.

${ }^{3}$ Jon Johansson, "Orewa and the Rhetoric of Illusion," Political Science 56, no. 2 (2004).
} 
[T]he National Party had been traditionally organised around fiefdoms at the electorate level and collective fiefdoms at the divisional level.... it was more a loose collection of similar thinking political organisations with similar outlooks than a [political party], which worked fine under FPP because essentially the electorate was the focus, but MMP requires a national consistent message to be delivered to voters and which the Party structure didn't [do] and it was essential but it depends on the structure which made it difficult to get it central, centralised, central control. ${ }^{4}$

The lack of central control limited the ability of National to fundraise, hire professionals, have a nationwide strategy or have a centralised advertising system.

\section{Financing Campaigns}

Internal organisational capabilities are an important factor in fundraising. Traditionally, National has financed its organisation and campaigning through membership fees, voluntary donations from members and contributions from other supporters, including corporations. ${ }^{5}$ Organisational capabilities to provide internal financing fell, however, largely as a result of falling party membership (see Appendix Three). National became more reliant on external sources of funding.

However, National was unable to attract significant corporate or individual donors. Donations and fundraising became part of the internal power play within National rather than a cause that united the Party. Divisions were to "supervise the collection of

\footnotetext{
${ }^{4}$ Subject B, Interview.

${ }^{5}$ Gustafson, The First 50 Years, 200.
} 
contributions to the Party funds", ${ }^{6}$ while the nationwide Finance Committee (until it was disestablished in 1997) was only to "assist, supervise and advise on the finances of the Party". 7 To donate to the Party, corporations or wealthy individuals would need to give the money via a division rather than being able to send the money directly to the National Management Board. But, given the split of the divisions by ideology/faction, the money would not simply move through to the Board. ${ }^{8}$ Instead, the division would then argue for that individual's or corporation's policy stance with the other divisions. In short, there was no guarantee that donating significant amounts of money to National would have any influence on the policy that National stood for at an election. However, smaller donations (which do not attach patronage or policy expectations) would still have been provided to the Party as National still had 'attractive' policies. It is thus unsurprising that other political parties, such as ACT, were in a better position to attract large-scale corporate donations than National.

The decline in National's internal and external ability to raise funding caused significant problems for the Party. National was financially strong in 1996 and had no trouble purchasing advertisements. ${ }^{9}$ However, the 1999 election placed National in a financially precarious position - National was only able to raise 87 percent of the money it spent. ${ }^{10}$ This debt continued to plague National and 30 percent of the funding for the 2002 campaign had to be spent on repaying debt and keeping the Party solvent. $^{11}$ At the 2002 election National was only able to spend \$1 million on its

\footnotetext{
${ }^{6}$ New Zealand National Party, "Constitution and Rules (1998)," 27.

${ }^{7}$ New Zealand National Party, "Constitution and Rules (1986)," 20.

${ }^{8}$ Subject B, Interview.

${ }^{9}$ Miller, Party Politics in New Zealand, 100.

${ }^{10}$ Tracy Watkins, "Losing campaign cost Nats \$1m," The Dominion Post, 26 October 2002.

${ }^{11}$ See: Dalziel, "General Debate Speech, 11 September 2002."
} 
campaign - half of what National had spent in $1999 .{ }^{12}$ National had attempted to fundraise vigorously in 2002 - a team of 16-20 fundraisers, headed by former National Minister of Finance Sir William Birch, sought corporate funds - but the same channels were being used by the ACT Party. ${ }^{13}$ ACT spent $\$ 1.6$ million during the campaign and Labour spent \$1.4 million; National was only the third largest party in terms of financial capability in the 2002 election.

National's internal organisation prevented donors being attracted to the Party. While the Party was able to receive some external funding, National was unable to match the external donations that Labour or ACT were receiving. While the relationship between money and votes is not direct, ${ }^{14}$ and campaigning spending regulations prevent significant inequities between parties, ${ }^{15}$ a party which is unable to adaquately fund a campaign is unlikely to succeed in winning votes. In order for National to win office, it needed to find some source of external funding.

\section{Rejection of Professionalisation}

National largely resisted the movement towards professionalisation in the Party. Within National there was a key rule to exclude paid staff from being able to act as a delegate or committee member - meaning the governance of the Party was left to

\footnotetext{
${ }^{12}$ Watkins, "Losing campaign cost Nats $\$ 1 \mathrm{~m} . "$

13 Fran O'Sullivan, "The cost of democracy," New Zealand Herald, http://www.nzherald.co.nz/feature/story.cfm?c_id=774\&objectid=2049298, 2002 (accessed: 5 October 2007).

${ }^{14}$ Bryce Edwards, "Shining a Light on Party Finance in New Zealand" (paper presented at the New Zealand Political Studies Association Conference, Wellington, 30-31 August 2007).

${ }^{15}$ See: Andrew Geddis, Electoral Law in New Zealand: Practice and Policy (Wellington: LexisNexis, 2007), 137-139, 151-152, 161-166.
} 
amateurs. ${ }^{16}$ It was traditional for National leaders to have significant involvement in the management of election campaigns. ${ }^{17}$

Even if those amateurs who governed the Party wished to hire professional campaigners, each division would want to hire its own professional campaigner rather than give power to one central advisor. Divisions traditionally hired their own staff rather than rely on head office appointments or volunteers. ${ }^{18}$ Any professional campaigner would be limited in their effectiveness by only dealing with one division. National's organisation did not create significant opportunity for professionalisation and the poor financial situation did not help.

In 2002 the National campaign committee included: Leader Bill English; Deputy Leader Roger Sowry; MPs Simon Power and Murray McCully; Parliamentary staffers Tim Grafton and Sue Foley; and President Michelle Boag. English and the committee largely stayed out of managing the campaign. Instead, National appointed a campaign director-general - Allan Johnston. However, Johnston had a "lack of political experience and personal authority, as well as limited strategic ability". ${ }^{19}$ While 2002 was the first campaign which attempted to use a professional adviser, it may have contributed to the poor election result as the leadership was not seen as carrying messages to the electorates and divisions to push the party vote, rather Johnston was.

\footnotetext{
${ }^{16}$ Wood, "National," 255.

${ }^{17}$ Miller, Party Politics in New Zealand, 181.

${ }^{18}$ Gustafson, The First 50 Years, 205-206.

${ }^{19}$ Miller, Party Politics in New Zealand, 181.
} 
Professionalisation is a common trend within political parties, especially those undergoing decline. ${ }^{20}$ It allows parties to understand what the voters are looking for and how they are best to be targeted. While there is a degree of cynicism around professionalisation, it has helped political parties win elections.

\section{Lack of Strategy}

The MMP environment requires major parties to build a coalition of voters from various groups. The median swing vote, so important in FPP, becomes one of the groups the Party needs to target. National's 1996, 1999 and 2002 campaigns were not MMP campaigns per se. When there was an attempt to run a nationwide strategy, it was undermined by the electorate candidates who saw the electorate method of entering Parliament as more legitimate than the list, ${ }^{21}$ and hence campaigned to best maximise their chances of being elected.

In 1996 the "cold reality of MMP campaigning hit many MPs". ${ }^{22}$ The electorates continued to be viewed by many members and elites as being the key to success, as President Geoff Thompson noted:

[National] believed firmly that the constituency organizations would be strong enough to campaign for their candidate or candidates and as a spin-off, generate the party vote attached to the candidate by association. ${ }^{23}$

\footnotetext{
${ }^{20}$ Mair, Müller, and Plasser, "Conclusion," 265.

${ }^{21}$ See: Leigh J. Ward, "'Second-Class MPs'? New Zealand's Adaptation to Mixed-Member Parliamentary Representation," Political Science 49, no. 2 (1998).

${ }^{22}$ Sowry, "The National Campaign," 27.

23 Thompson, "Preparing the Party for MMP".
} 
While there was some nationwide focus and targeting of specific groups, National did not have an overall focus on the party vote aspect. Electorates focused on the same groups as they had done under FPP, rather than the multitude of groups needed to win under MMP.

In 1999 National faced a lack of overall strategy as well, with Annabel Young noting:

Even amongst National supporters there was confusion about National's overall strategy.... From the inside, it appeared that the National campaign demonstrated good operational control, but even party activists were unclear about strategy. This made it difficult to integrate their actions into the strategy. In some cases, it led to local paralysis. $^{24}$

The communication between electorates and the central campaign control fell apart. Some electorates largely campaigned for the electorate vote using their own strategies and resources. National did not target any set of voters consistently with the central and local bodies of the Party clashing.

The 2002 election, the nadir of National's support, again had no over-riding strategy. In a leaked copy of National's self-review, the Party admitted it 'forgot' to seek the party vote. ${ }^{25}$ National attempted to undermine Labour's support by getting voters to give the government a scare by voting National. As Tim Grafton notes:

This strategy failed, partly because the message was communicated poorly by the campaign advertising in the early stages of the campaign, partly because the gap

\footnotetext{
24 Annabel Young, "Strategy, Tactics and Operations: National's Campaign," in Jonathan Boston, Stephen Church, Stephen Levine, Elizabeth McLeay, and Nigel S. Roberts (eds.), Left Turn: The New Zealand General Election of 1999, (Wellington: Victoria University of Wellington, 2000), 34-35.

${ }^{25}$ See: Dalziel, "General Debate Speech, 11 September 2002."
} 
between National and Labour created a 'relevance' issue, and partly because the party's campaign failed to focus on the party vote. ${ }^{26}$

Again, National did not target specific key groups of voters. Instead it focused on trying to build discontent with the Labour-led government, forgetting that being discontent with Labour no longer necessarily meant voting National in the multi-party environment.

All the campaigns demonstrated a lack of central strategy in gaining the party vote. National further demonstrated a lack of understanding about the nature of campaigning in a multi-party system. At each election the electorates felt that their campaign was more important and relevant than the nationwide campaign (in 1996 the central campaign team even accepted this) and thus undermined any cohesive strategy that the central campaign team tried to enact.

\section{$\underline{\text { Un-Coordinated Advertising }}$}

The early MMP elections had seen National ineffectively advertising itself - the focus was not on the party vote and messages failed to come across to the voters. Each electorate largely had control over the advertising within its electorate. The only nationwide medium, television, was poorly used by the central campaign team.

National billboard campaigns, for all three elections, were poor. The 2002 campaign provides a perfect case study. During the 2002 campaign it was not until two weeks before the election day that a billboard featured Leader Bill English - and when the

\footnotetext{
${ }^{26}$ Grafton, "National's Campaign," 114.
} 
billboards came out they were regarded as weak and not highlighting the party vote strongly enough. ${ }^{27}$ Furthermore, the "National Party's electorate hoardings were all over the place... totally uncoordinated.... The party simply did not have a generic model which its candidates could adopt and then adapt to fit their needs." 28 There was a wide variety of different billboards in use, and they did not necessarily even mention the National Party (see Figure 6.1). The decentralised organisation made each electorate responsible for its own electorate billboard. Electorates had the option of centrally ordering billboards, but there was no push for them to do so and few did. ${ }^{29}$

Figure 6.1 2002 National Electorate Billboards ${ }^{30}$

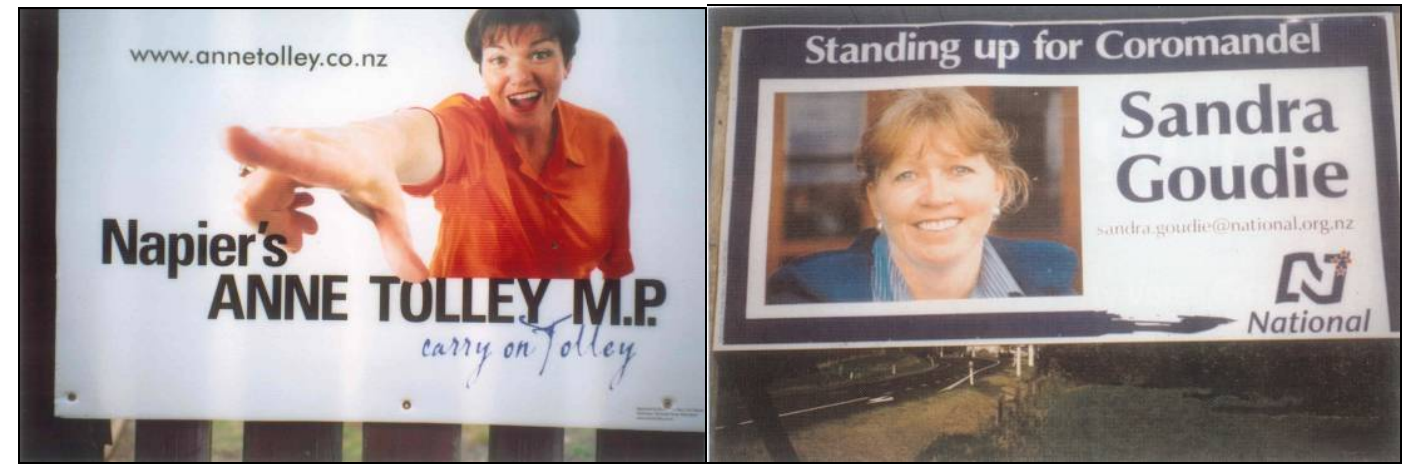

Electorates traditionally also held responsibility for campaign literature such as pamphlets. Each electorate was able to produce its own pamphlets and decide which letterboxes to place the information in. For the 1996 and 1999 elections these pamphlets were collated by Victoria University of Wellington academics. National's resources were focused on 'fairly safe electorates' in 1996 with less attention given to

\footnotetext{
27 Nigel S. Roberts, "All Over the Place: Billboards Battles in 2002," in Jonathan Boston, Stephen Church, Stephen Levine, Elizabeth McLeay, and Nigel S. Roberts (eds.), New Zealand Votes: The General Election of 2002, (Wellington: Victoria University Press, 2003), 271-272.

${ }^{28}$ Roberts, "All Over the Place," 272.

${ }^{29}$ Subject C, Interview.

${ }^{30}$ Both billboards were photos taken by Nigel S. Roberts who retains copyright. They were published in the photographic collection accompanying: Roberts, "All Over the Place."
} 
'safe electorates' and 'marginal electorates'.31 At the 1999 election, National emphasised the party vote in only 46.2 percent of pamphlets, with 53.8 percent emphasising the electorate candidate; Labour emphasised the party vote in 56.9 percent of the pamphlets. ${ }^{32}$ Some lessons were learnt - for instance in 1996 some National candidates produced pamphlets with orange, rather than blue, backgrounds, ${ }^{33}$ whereas in 1999 "most National material was produced on a blue background in the motif of a billowing New Zealand flag." 34 Yet this was forgotten in 2002 as there "was not even a central party direction that all party material be printed in the party's colour of blue!" 35 The electorate control prevented structured nationwide control over pamphlet material and resulted in a strong focus on the electorate candidate and poor targeting of information towards selected groups of voters.

Within New Zealand television is a largely nationwide medium and hence political parties cannot limit their television campaigning to specific geographic areas. However, radio stations are still localised and offer a better opportunity for electorate candidates to use an electronic medium. Hence it would be expected that a decentralised party would use radio for electorate campaigns and television for party vote campaigning.

\footnotetext{
31 Margaret Cousins and Elizabeth McLeay, "Leaflets, Letterboxes and Litter: Candidates and their Campaigns," in Jonathan Boston, Stephen Levine, Elizabeth McLeay, and Nigel S. Roberts (eds.), From Campaign to Coalition: The 1996 MMP Election, (Palmerston North: Dunmore Press, 1997), 87.

${ }^{32}$ Hilary Pearse, "'No Junk Mail': The Street-Level Campaign," in Jonathan Boston, Stephen Church, Stephen Levine, Elizabeth McLeay, and Nigel S. Roberts (eds.), Left Turn: The New Zealand General Election of 1999, (Wellington: Victoria University Press, 2000), 132.

${ }^{33}$ Cousins and McLeay, "Leaflets, Letterboxes and Litter," 93-94.

${ }^{34}$ Pearse, "'No Junk Mail'," 136.

${ }^{35}$ Chris Rudd and Janine Hayward, "Campaigning," in Raymond Miller (ed.), New Zealand Government and Politics, (Melbourne: Oxford University Press, 2006), 335.
} 
Unfortunately there is little data available on radio advertising within New Zealand. However one interview subject noted that radio has not been a significant medium for the National Party. There has been little demand from the electorates to use radio as a campaign tool within the ninety-day election spending period. Electorates did not ask for an allocation of the state funding provided for television and radio advertising. A number of electorates have been able to use radio advertising outside of the ninety-day period in order to build awareness of the candidate, not of the National Party. ${ }^{36}$

Television campaigning has been a significant tool for National. Television was the most centralised aspect of National's campaign, largely due to the structure of opportunities within television as a nationwide medium rather than due to any decision within the Party itself. In 1999 National used a combination of positive and negative (anti-Labour/Alliance) adverts, but the negative advertisements appeared to be acts of desperation rather than a legitimate campaign tactic. ${ }^{37}$ During the 2002 election, National's opening broadcast failed to mention the party vote, the advertisements ignored Bill English's strengths and the messages were poorly constructed. ${ }^{38}$ The campaign teams in 1999 and 2002 were unable to effectively use the main central tool at their disposal largely due to their inability to link all party advertising together in one unified strategy.

\footnotetext{
${ }^{36}$ Subject C, Interview.

${ }^{37}$ Stephen Church, "Lights, Camera, Election: The Televsion Campaign," in Jonathan Boston, Stephen Church, Stephen Levine, Elizabeth McLeay, and Nigel S. Roberts (eds.), Left Turn: The New Zealand General Election of 1999, (Wellington: Victoria University Press, 2000), 110-111.

${ }^{38}$ Claire Robinson, "The Party Vote, Populism and Political Advertising in 2002," in Jonathan Boston, Stephen Church, Stephen Levine, Elizabeth McLeay, and Nigel S. Roberts (eds.), New Zealand Votes: The General Election of 2002, (Wellington: Victoria University Press, 2003), 236-237, 250-252.
} 


\section{$\underline{\text { Re-Organisation }}$}

The 2003 review brought many elements of the Party under the control of the central National Management Board. The Board gained control over finances and the campaign. The re-organisation created a structure with better opportunities for professionalisation, a central unified party-vote strategy and uniform advertising. The changes made to National were of significant benefit to the 2005 election campaign.

\section{Finance}

The centralisation process changed the internal structure so that it becomes more suited towards receiving corporate donations. The review gave the Board "full responsibility for the finances of the Party. It shall have the power... to deal with the business and property of the Party." ${ }^{39}$ Corporations or wealthy individuals seeking to donate would be able to deal directly with the National Management Board rather than with a region. Although there is little indication that corporate funding was one of the aims of the restructuring, it was a significant by-product of the decision to bring control of the Party into the centre.

Any additional funding within National may allow the Party to have a more active, professional and standardised campaign than it previously had. If the Board provides funds to the regions and electorates then they have a greater say over the nationwide and electorate campaign. However, if the electorates and regions provide income to the Board, as previously happened, ${ }^{40}$ then the electorates will have some leverage over the

\footnotetext{
${ }^{39}$ New Zealand National Party, "Constitution and Rules (2003)," 16.

${ }^{40}$ Gustafson, The First 50 Years, 204-205.
} 
nature of their campaign. ${ }^{41}$ It is important, for the nationwide strategy MMP requires, that the Board has substantial income separate from levying electorates for funding.

National's, former, decentralised organisation limited the ability of the Party to have enough campaign funds and the ability of corporate donors to influence the Party's policies. The new centralised organisation increased the Party's ability to secure substantial campaign funds. However, the new organisation also provides a greater opportunity for external donors to influence policy and strategy within National which could potentially undermine the traditional grassroots of the Party. Other factors - such as leadership, polling, experience, membership figures and party funding laws influence whether these opportunities are taken up or not.

\section{Professionalisation}

The centralisation process created an opportunity for professionalisation to develop. As MMP requires a more sophisticated electoral strategy throughout the country, professional advisors are likely to be of some benefit. Professionalisation also includes the use of data analysis systems, polling techniques, and strategic advice which allows parties to figure out how to maximise their vote throughout the country.

With governance and campaign management located within one single authority, the effectiveness of professionalisation increases significantly. The Board becomes more likely to seek external advice as it is clear that responsibility for campaigning lies on its

\footnotetext{
${ }^{41}$ Subject B, Interview.
} 
shoulders and not on those of the regions. Furthermore, with a single financial centre the Party is more likely to be able to afford to hire external consultants.

Not only was the Board more likely to be willing to appoint external professional campaigners; but more importantly the organisation was more conducive to attracting professionals, as Dennis Kavanagh notes:

The marketing men prefer a party that is centralised, leader friendly, allows them direct access to the key decision-makers, including the leader, and grants much autonomy to the people they liaise with- usually the party's communication directors. Internal debate should be sacrificed in the interests of presenting a clear message. It should have what Philip Gould, [Tony] Blair's polling strategist, calls 'a unitary command structure'. Party activists thrive in the inner-directed party; marketing professionals look to an outer-directed party. They give different answers to the question of who counts. For the former it is the members who need to be courted, for the latter it is the voters who need to be won over. $^{42}$

National was more likely to hire external consultants after the centralisation process than before, and these professionals could arguably have significant control and influence within the Party.

\footnotetext{
${ }^{42}$ Dennis Kavanagh, "Party Democracy And Political Marketing: No Place For Amateurs?" (paper presented at the Political Communications in the Global World Conference, Mainz, 30-31 October 2003), $2-3$.
} 


\section{Control Over Strategy}

Previously National left electorate strategy to each electorate with a minimal nationwide strategic overview. The centralisation process substantially weakened the control regular party members had over the Party itself. As party members are notably more radical than their elite counterparts, ${ }^{43}$ the removal of direct relations between members and elites allowed the elites more flexibility in controlling the party's policy and strategy. Even though elites are still sensitive to member concerns and are unlikely to remove policy without just cause - such as it being unpopular with core segments of society - the policy put forward by National is more likely to seek out set groups of voters.

National has traditionally been able to seek out the median voter and, to some extent, ignore core National voters who were not in key swing seats. An MMP environment though requires National to target its 'natural' voters as well. Targeting traditional National voters became a problem for National under MMP as it has two distinct groups - urban liberals and rural conservatives - to appeal to. However, there are some unique strategic devices to deal with this problem such as 'dog-whistle' and 'wedge' tactics.

A dog-whistle is a deliberately ambiguous message that appeals to a certain prejudice of one set of voters, while those without those views do not recognise it as being prejudicial. National was limited in its ability to use dog-whistle tactics before the centralisation process. Previously, divisions had the ability to craft messages specific

\footnotetext{
${ }^{43}$ John D. May, "Opinion Structure of Political Parties: The Special Law of Curvilinear Disparity," Political Studies 21, no. 2 (1973).
} 
to each electorate or division and so there was, in their view, no need to 'hide' their message by using such a tactic - rather they could be explicit and clear as to what they meant. The liberal areas could use liberal messages and the conservative areas could use conservative messages. The leadership would then have to use compromise positions between the two factions. However, with a nationwide campaign system, the effectiveness of dual-messaging falls apart. The re-organisation moved control of campaign material to the campaign team which increased the ability of the Party to use dog-whistle messages. Potentially, dog-whistle politics allows National to rebuild both the liberal and conservative constituencies separately without disturbing the other.

A wedge tactic aims to attack another party's policy towards an identity group (usually an ethnic group) in order to make the other party defend the group's rights so as to highlight that the other party is more concerned with minority groups than with the majority. ${ }^{44}$ The centralisation created an opportunity for the Party elites to use 'antiMāori' wedge tactics as internal resistance was weakened. Prior to the centralisation of National's organisation, Māori concerns about the direction of the Party were able to be represented with a Māori vice presidency who acted as a veto player on such tactics. ${ }^{45}$ Concerns may have also come from the liberal Auckland and Wellington divisions and their associated vice presidencies and representatives. The development of a wedge tactic may have led to significant internal turmoil within the National Management Board. The Board may have been unwilling to approve of wedge advertising and policy in an election campaign. However the centralisation process saw the removal of the Māori and divisional vice presidencies and representatives from the National

\footnotetext{
${ }^{44}$ Sarah Maddison, "Ideas from 'Across the Ditch'? Wedge Politics in the 2005 New Zealand Election," Australian Journal of Political Science 41, no. 3 (2006); Shaun Wilson and Nick Turnbull, "Wedge Politics and Welfare Reform in Australia," Australian Journal of Politics and History 47, no. 3 (2001).

${ }^{45}$ For a parallel with the removal of the Māori seats, see: Gustafson, The First 50 Years, 252.
} 
Management Board. Hence the Party gained another strategy to deal with the MMP environment.

\section{Control over Advertising}

The centralisation process allowed National to campaign coherently throughout the country. The central control limited the ability of electorates to run their own campaign. All electorate advertising needs to be approved of by the central campaign team located within the head office. Indeed, one interview subject noted:

It was much tighter control than in the previous campaigns. Mainly because of the review of the 2002 election where there wasn't enough control.... [It was] just the basics of everyone using the same colour, having the same logo, the same brochures generally et cetera. ${ }^{46}$

The centralisation resulted in allowing the campaign team to have a more effective, unified nationwide campaign.

The previous decentralised organisation made each electorate responsible for their own billboards and pamphlets. While electorates had the option of centrally ordering billboards, it was optional. The centralisation process brought control over the design of billboards to the National Management Board in order to produce more effective and standardised electorate billboards that sought both the electorate vote and the party vote. For pamphlets, each electorate was still responsible for the design, but "you have to get permission from headquarters, so one of the headquarters campaign staff has [to]

\footnotetext{
${ }^{46}$ Subject C, Interview.
} 
sign off the pamphlet.... They do have the ultimate [say]". ${ }^{47}$ All advertising was either to be created, ordered through, or approved by the central campaign team and not done on an electorate-by-electorate basis.

With advertising brought into the centre, the party vote element should be pushed more strongly. Furthermore, the new strategies available to the Party could be expected to be present in all advertising. Professionalisation should change who was targeted and improve the quality of advertising. The changes did have an impact in the 2005 election campaign as explained in the next section.

\section{Election Campaign}

The 2005 election was called by Helen Clark for 17 September 2005. Labour had a significant poll lead going into the election year. ${ }^{48}$ The new organisational structure provided National with the opportunity to campaign more consistently throughout the country. While National lost the election, their campaign was their best MMP campaign so far and that was reflected in their vote share - the highest for National since the 1990 election landslide.

\section{$\underline{\text { Corporate Finance }}$}

In the lead up to the 2005 election National successfully raised substantial amounts of money. National's true bank account for 2005 was "bulging the purse to an extent that

\footnotetext{
${ }^{47}$ Subject C, Interview.

${ }^{48}$ de Malmanche, "'Events, My Dear Boy'," 559.
} 
will never be made public."49 There are a number of estimates available. National's declared donations for 2005 totalled $\$ 1.88$ million. This figure is unreliable, as all donations under $\$ 10,000$ need not be declared and the figure does not include money raised in 2003 and 2004 which also went towards National's 2005 campaign. National declared its election expenditure to be $\$ 2.1$ million - but this figure also misses many expenses such as employing consultants and any advertising more than three months before the election. However, Steven Joyce noted that for the 2005 election National would "need to look at raising about $\$ 2.8$ million dollars [sic] from fundraising activities, over and above electorate levies and the President's appeal". ${ }^{50}$ Whatever the true amount of money raised and spent in 2005, it was much larger than any amount National had ever spent in an election before. ${ }^{51}$

Many of the donations National received were reciprocated in the form of providing access to the leadership or input into policy, or both. It is folly to expect substantial donations not to have some sort of reciprocation attached. ${ }^{52}$ Many of the significant donations were from corporations with potentially much to gain from the election of a National-led government. For instance, pharmaceutical company Pfizer purchased a table at a fundraising event for roughly $\$ 5000$ - Pfizer stood to gain from National's policy of reviewing the state pharmaceutical purchasing agency Pharmac. ${ }^{53}$ National had several meetings over privatising accident compensation with the Insurance Council and when the policy was released Insurance Council CEO Chris Ryan privately

\footnotetext{
${ }^{49}$ Nicky Hager, The Hollow Men: A Study in the Politics of Deception (Nelson: Craig Potton Publishing, 2006), 223.

${ }^{50}$ Quoted in: Hager, The Hollow Men, 214.

${ }^{51}$ Hager, The Hollow Men, 212.

${ }^{52}$ Karl-Heinz Nassmacher, "Comparative Political Finance in Established Democracies," in Karl-Heinz Nassmacher (ed.), Foundations for Democracy: Approaches to Comparative Political Finance: Essays in Honour of Herbert E. Alexander, (Baden-Baden: Nomos Verglagsgesellschraft, 2001), 24.

${ }^{53}$ Hager, The Hollow Men, 218.
} 
stated that the policy was "very positive for the industry"; 54 the Insurance Council reportedly gave $\$ 1$ million to National's campaign. There was little internal debate about the policies decided upon by the party elites - the structure was set up to give more power to the centre.

However, the situation regarding corporate financing of National's campaign may not be a long-term trend within the National Party. In 2005 the Party elites were largely inexperienced in grass-roots fundraising and preferred to use their much greater corporate links - for instance General Manager Steven Joyce had not been active, except as the co-ordinator of the 2003 review, in the Party before but had served as CEO of Radioworks Ltd. Furthermore Leader Don Brash was well recognised within the finance community as being business friendly - Brash had served fourteen years as Governor of the Reserve Bank and had links with several wealthy businesspeople. It is unlikely that such a move towards corporate funding would have occurred without the centralisation process, yet it is equally important that the corporate donors had friendly faces to approach in Brash and Joyce. The negative public reaction to the publication of the relationship between National and its donors saw Leader Don Brash resign in late-2006, and may serve as a warning to future leaders.

\section{Professional Advisers}

The 2005 campaign saw National use external professional advisers - indeed the extent of their use within National was unprecedented within New Zealand. The only MP within the key advisor group to Leader Don Brash was Murray McCully, although

\footnotetext{
${ }^{54}$ Quoted in: Hager, The Hollow Men, 247.
} 
Deputy Leader Gerry Brownlee was occasionally involved. Bryan Sinclair (a rightwing activist mentored by prominent neo-liberal Roger Kerr), Matthew Hooton (a public relations consultant) and Peter Kennan (a neo-liberal economist) were brought in by Brash through his Parliamentary Leader's Fund. Richard Long, formerly editor of The Dominion, remained from former-Leader Bill English's staff. Outside of Parliament, former Radioworks CEO and 2003 review co-ordinator Steven Joyce was appointed General Manager of National in 2003. Of those close to Brash during the campaign only Long and McCully had had significant interaction with National previously - the others were professional outsiders brought in for their specific experience in order to get National elected. ${ }^{55}$

For the election campaign itself, National hired Mark Textor from Crosby|Textor - an Australian company dedicated to strategy, market research and campaigning. Crosby|Textor was previously involved in the Australian Liberal Party’s 1996, 1998, 2001 and 2004 successful campaigns; the United Kingdom Conservative Party's 2005 highly professional and controversial, albeit unsuccessful, campaign; and British American Tobacco's constant uphill battle against regulation and anti-smoking campaigns. Crosby|Textor was well known for its tactics of 'push-polling', dog-whistle politics and wedge tactics. ${ }^{56}$

John Ansell was brought into National to organise television, radio, billboard and pamphlet advertising. Ansell's background was in advertising, especially political party campaigns. Ansell had won the Mobil Radio Award for the 1993 Labour Party

\footnotetext{
${ }^{55}$ Hager, The Hollow Men, 19, 57.

${ }^{56}$ Hager, The Hollow Men, 152-156.
} 
campaign. Since 1996 Ansell had been a firm ACT supporter and had organised their election advertising in previous MMP campaigns. Don Brash's leadership of National attracted Ansell to the Party. Richard Long organised for Ansell to be paid out of the parliamentary leader's fund - even though none of his advertisements were fundable by Parliamentary Services. ${ }^{57}$

The professional strategists rejected input from National members. Bryan Sinclair, and others close to Don Brash, used the term 'the dark side' to refer to movements and people within National, not to Labour or other Left-wing movements. ${ }^{58}$ Matthew Hooton and Sinclair worried about Brash becoming a "prisoner of the caucus". 59 Peter Keenan felt that President Judy Kirk was "not that important in the scheme of things" ${ }^{60}$ The internal political structure was largely ignored by the professionals. Instead the professionals preferred to rely on their own experience, training and market analysis.

National's campaign strategy was substantially informed by these external professionals. The professionals were the closest advisors to Don Brash and often recommended him not to listen to other forces within National. The dominance of the professionals saw National run its most professional, vote-seeking MMP campaign.

\section{Multiple Strategies for the Party Vote}

In 2005 a new centralised strategy was used to make sure National received the largest vote share; a further objective was to ensure that the Green Party fell below the five

\footnotetext{
${ }^{57}$ Hager, The Hollow Men, 181-182.

${ }^{58}$ Hager, The Hollow Men, 68-69.

${ }^{59}$ Quoted in: Hager, The Hollow Men, 82.

${ }^{60}$ Quoted in: Hager, The Hollow Men, 119.
} 
percent threshold to limit Labour's coalition options. ${ }^{61}$ The strategy focused on several different aspects. National accepted that to win the election they would need to build a coalition of voters by capturing the swinging voter through directly appealing to the 'middle ground' as well using dog-whistle and wedge tactics to appeal to different Right-wing voters. These strategies required a more flexible leadership that was not bound to the traditional National Party base, and the centralisation provided that flexibility.

Crosby|Textor was employed to carry out focus groups of non-affiliated voters - those crucial to winning an election. Their aim was not to find out what the voters were thinking or wanted - but rather how their perceptions could be changed and how, with 'prompting', voters could see problems with the Labour-led government's policy. For instance, voters felt that tax cuts missed the point and were happy about the state of the economy. However, when focus group members were prompted they felt that Labour lacked a plan to keep the economy growing. National was thus able to link the longterm economic concern with its policy of cutting taxes. ${ }^{62}$ Due to National's tax cut campaign "more voters identified tax as their number one issue of personal concern than any other issue". ${ }^{63}$ Crosby|Textor's use of focus groups allowed National to find how their centre-Right policies could target the median voter through clever use of messages.

Not only did Crosby|Textor work on how to package policies, but they worked on agenda setting and policy creation. For instance, Crosby|Textor recommended focusing

\footnotetext{
${ }^{61}$ Hager, The Hollow Men, 134.

${ }^{62}$ Hager, The Hollow Men, 158.

${ }^{63}$ Levine and Roberts, "Mixed Messages," 373.
} 
on immigration as a key issue and recommended that National's policy focus on only allowing skilled migrants to enter New Zealand, ${ }^{64}$ Don Brash later stated that "immigrants must be likely to provide a net benefit to existing New Zealanders". 65 Further recommendations were made to focus on Helen Clark's personality. One of Clark's virtues at the previous election was that she was seen as having integrity, competence and being trustworthy; ${ }^{66}$ Brash attacked the Labour-led government as being "rotten to the core" and that "one will be amazed that Helen Clark's nose is not three feet long". 67

National realised that a number of its policies would be unpopular with the median voter and decided that these policies needed to be 'inoculated'. Three Labour policies were seen as being well supported by the public - four-week annual leave for workers, rejection of privatisation and the increased superannuation rate. If National opposed these policies then they were likely to lose votes. National believed they had already dealt with nuclear policy and the perception that tax cuts were simply for the rich. Richard Long noted that:

We [the National Party] are constantly being seen to embrace Act [Party views], or employers, and being worker unfriendly (eg four weeks leave) which means we frighten off many of those blue collar male Labour voters that Don [Brash] dragged across the divide on Orewa. ${ }^{68}$

\footnotetext{
${ }^{64}$ Hager, The Hollow Men, 159.

${ }^{65}$ Quoted in: New Zealand Press Association, "National sets out 'disciplined' immigration plan," New Zealand Herald, http://www.nzherald.co.nz/section/1/story.cfm?c_id=1\&objectid=10339908, 2005 (accessed: 24 October 2007).

${ }_{67}^{66}$ Johansson, "Leadership and the Campaign," 61, 65.

67 Quoted in: Ruth Berry, "No bite in Brash's baloney," New Zealand Herald, http://www.nzherald.co.nz/section/1/story.cfm?c_id=1\&objectid=10127538, 2005 (accessed: 24 October 2007).

${ }^{68}$ Quoted in: Hager, The Hollow Men, 125.
} 
Slowly the issues were 'inoculated' - either through simply accepting Labour's policy (four-week annual leave, superannuation) or through vague statements which implied acceptance (privatisation). ${ }^{69}$

Internally the inoculation measures were unpopular throughout the ranks of the Party. Don Brash wrote that he was "left worrying what it is that I will actually achieve by winning the election - maintaining a whole lot of dopey Labour policies". ${ }^{70}$ Peter Keenan noted that "some core supporters [party members]... are almost barking mad when it comes to choosing a package of measures that enough people might vote for". ${ }^{71}$ Keenan justified the inoculations by stating that "the policies that National/Brash stand for are not widely enough shared in the community to win an election, and most core supporters will understand that" ${ }^{72}$ However, the policies were never completely removed from the plans for when National won the election - just for what they campaigned on. ${ }^{73}$ National's inoculations represent classic vote/office seeking behaviour of political parties.

National's plan to reclaim the centre-ground through clever messaging, selecting populist policies, hiding unpopular policy and attacking Labour was not their only strategy. National also imported two strategies from the Australian Liberal Party, via Crosby|Textor, to help win the 2005 election - dog-whistle and wedge tactics. These strategies were not aimed at the median voter but instead sought to bring together the

\footnotetext{
${ }^{69}$ Hager, The Hollow Men, 126-127.

${ }^{70}$ Quoted in: Hager, The Hollow Men, 61.

${ }^{71}$ Quoted in: Hager, The Hollow Men, 64.

${ }^{72}$ Quoted in: Hager, The Hollow Men, 61.

${ }^{73}$ Hager, The Hollow Men, 62-63.
} 
divergent Right-wing voters who had, at previous MMP elections, voted for minor Right-wing parties rather than National.

The opportunity for the use of dog-whistle politics rose and it was taken up during the 2005 campaign. National employed dog-whistle tactics on numerous issues - however the prime examples were the use of the phrases 'political correctness' and 'mainstream'. Both phrases are deliberately vague and are used against minority groups perceived as having significant power.

The phrase 'politically correct' is received differently by different audiences, Nicky Hager notes that:

To one audience the messages purport to be a commonsense dismissal of silly excesses; to others they are an invitation to sneer at feminism, to feel comfortable talking about 'cripples', 'faggots' and 'coconuts' and to put the boot into Maori [sic]. ${ }^{74}$

National focused strongly upon Labour's 'politically correct' policies during the 2005 campaign. Gerry Brownlee attacked Labour's policy of ensuring teachers can pronounce Māori properly as being "politically correct tokenism". ${ }^{75}$ A decision not to drain Mount Ruapehu's crater lake, which may have created a dangerous lahar such as the 1953 lahar that killed 151 people, saw Brownlee state that "the Government chooses to put political correctness before lives."76 Each of these statements linked Labour's policy decisions with 'pandering' to Māori instead of creating policy that

\footnotetext{
${ }^{74}$ Hager, The Hollow Men, 168.

75 Quoted in: Jon Stokes, "Labour - speak Maori properly," New Zealand Herald, http://www.nzherald.co.nz/section/1/story.cfm?c_id=1\&objectid=10342696, 2005 (accessed: 25 October 2007).

${ }_{76}$ Gerry Brownlee, "A great time to be in National," Scoop, http://www.scoop.co.nz/stories/PA0503/S00418.htm, 2005 (accessed: 25 October 2007).
} 
benefited all New Zealanders. However at the same time, quite different meanings could have been taken by those who do not hear the dog-whistle, instead believing that National's message was that the government had lost its way and produced poor policy.

The key message throughout the election campaign for National was that while they represented 'mainstream' New Zealanders, Labour did not. In his speech to National's 2005 Annual Conference Brash stated that:

$[\mathrm{M}]$ iddle New Zealand - hard-working average income families - know that the serious issues confronting them in their daily lives are just not being addressed. This Clark Government, you see, is not a government of mainstream New Zealand, for mainstream New Zealand. $^{77}$

At the same conference Gerry Brownlee used 'mainstream' fifteen times during his speech. ${ }^{78}$ Again, these messages were aimed at selected segments of voters - white, middle class, male voters - while not being immediately offensive or off-putting to other segments of society. Brash did not wish to elaborate on who was, and was not, a member of the 'mainstream' New Zealand political discourse - doing so would undermine the entire purpose of using dog-whistle tactics. Yet Brash had to deal with media analysis of what 'mainstream' meant and struggled to come up with an acceptable definition to potentially swinging voters during a TV3 election debate. ${ }^{79}$

\footnotetext{
77 Don Brash, "New Zealand Needs A Change Of Government," Scoop, http://www.scoop.co.nz/stories/PA0506/S00625.htm, 2005 (accessed: 25 October 2007).

${ }^{78}$ Hager, The Hollow Men, 253.

79 Kate McMillan, "Winning the Metadebate: New Zealand's 2005 Televised Leaders' Debates in Comparative Perspective," in Stephen Levine and Nigel S. Roberts (eds.), The Baubles of Office: The New Zealand General Election of 2005, (Wellington: Victoria University Press, 2007), 226.
} 
Dog-whistle tactics were predominately used by National to substantially rebuild its conservative base without scaring away the liberal vote. However, there were instances of National using it to appeal to their liberal voters. For instance, on the issue of privatisation John Key stated that National was interested in "what will make the boat go faster", ${ }^{80}$ and that privatisation would be off the agenda "for at least our first term in office". ${ }^{81}$ The message to neo-liberal voters was that privatisation was clearly on the agenda, just not in the short-term, whereas conservative voters would feel that largescale privatisation was unlikely to occur and small-scale privatisation may occur later on. The conflicting messages predominately served National well.

Along with dog-whistle messages, National also introduced to New Zealand wedge tactics. The tactic originated in Australia and was transferred to New Zealand. ${ }^{82}$ The wedge tactic aimed to exploit the ethnic tension within New Zealand by attacking Labour's Māori policies, thus making Labour defend Māori rights, in an attempt to make Pākehā vote National. The tactic was well used by National in 2004 and 2005.

In 2004 Don Brash gave a speech entitled 'Nationhood' to the Orewa Rotary Club. The speech focused on "the dangerous drift towards racial separatism in New Zealand, and the development of the now entrenched Treaty grievance industry." 83 Brash was largely negative about Māori, with three negative statements for every positive one. ${ }^{84}$ The aim of the Orewa speech was to "put the shits up Labour and force them into a more radical 'pro' Maori [sic] position and [for National to] pick up red neck votes as

\footnotetext{
${ }^{80}$ Quoted in: Hager, The Hollow Men, 126.

${ }^{81}$ Quoted in: Hager, The Hollow Men, 127.

${ }^{82}$ Maddison, "Ideas from 'across the ditch'?."

83 Don "Nationhood," New Zealand National Party, http://www.national.org.nz/Article.aspx?ArticleID=1614, 2004 (accessed: 26 October 2007).

${ }^{84}$ Johansson, "Orewa and the Rhetoric of Illusion."
} 
well." ${ }^{85}$ The speech successfully linked Labour with Māori separatism and with giving iwi too many rights to the foreshore and seabed. Labour was immediately forced to defend Māori-specific polices and race-based funding, ${ }^{86}$ although later Labour announced a review of race-based programmes. ${ }^{87}$ The Orewa speech and its fallout resulted in a 17 percent poll increase for National. ${ }^{88}$

\section{Figure 6.2 National Party 'Iwi/Kiwi’ Billboard ${ }^{89}$}

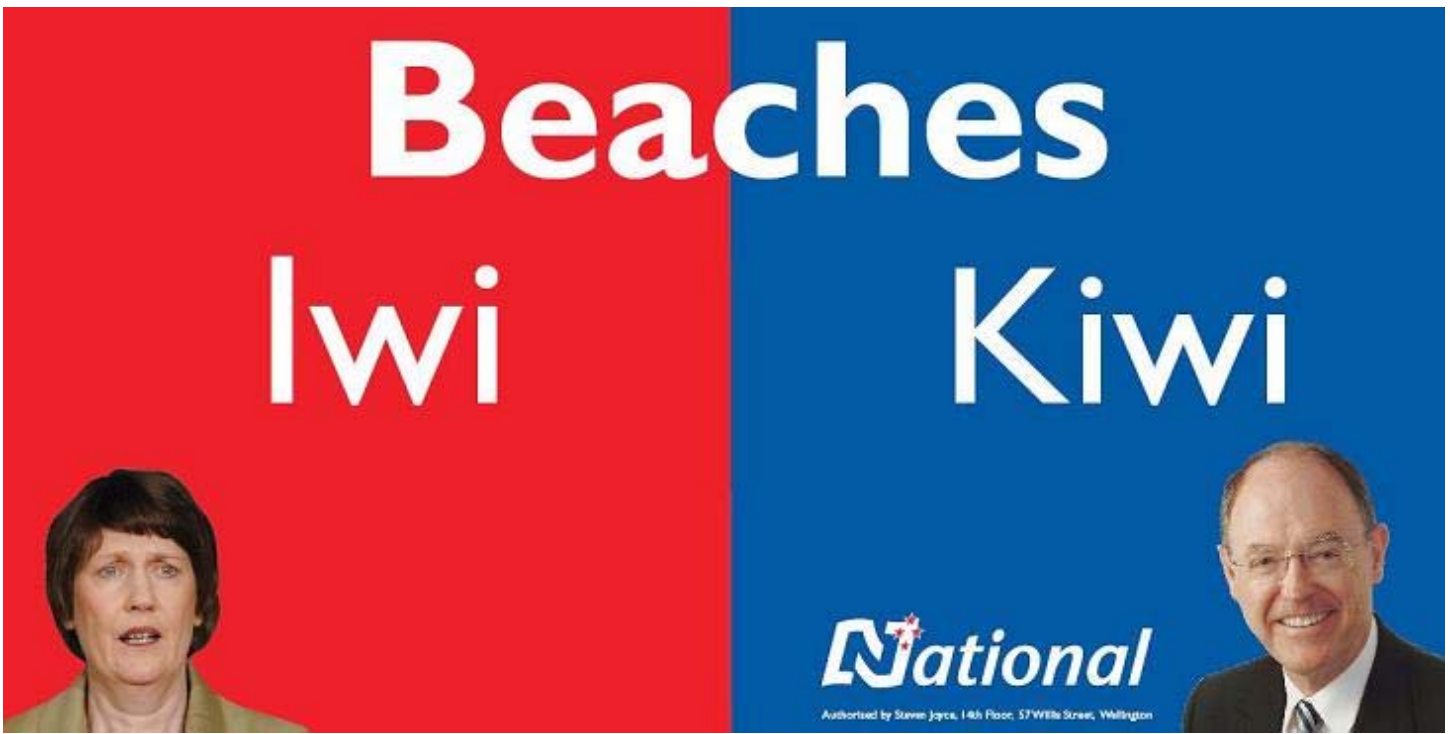

During the 2005 election campaign National continued to use wedge tactics in relation to Labour and Māori. The connection was made explicitly in one particular election billboard. At the top was the word 'Beaches', referring to the foreshore and seabed debate; on the left-hand side was Helen Clark on a red background with 'Iwi'; on the right-hand side Don Brash was on a blue background with 'Kiwi' (see Figure 6.2). The

\footnotetext{
${ }^{85}$ Matthew Hooton, quoted in: Hager, The Hollow Men, 81.

${ }^{86}$ Tara Ross, "Clark laments divisive politics," The Press, 5 March 2004.

${ }^{87}$ New Zealand Press Association, "Scrutiny of Maori smoking programme welcomed," New Zealand Herald, http://www.nzherald.co.nz/section/1/story.cfm?c_id=1\&objectid=3584112, 2004 (accessed: 30 October 2007).

${ }^{88}$ Johansson, "Orewa and the Rhetoric of Illusion."

${ }^{89}$ Image taken from: New Zealand National Party, "Send An e-Card," New Zealand National Party, http://www.national.org.nz/Ecards.aspx, 2005 (accessed: 24 October 2007).
} 
message was clear - Labour would give Māori rights to the beaches whereas National would ensure that all New Zealanders could access the beaches. The billboard separated off different groups - one side was Māori and Labour; the other side was non-Māori and National - the billboard aimed to make non-Māori vote National. The divisive nature of the billboard was denied by National, with Steven Joyce stating "with the iwi being part of the word Kiwi as well.... obviously that includes iwi and that's part of the message of the billboard." 90 The billboard was also an attempted dogwhistle. Labour was clearly linked by National to being strongly in favour of Māori and not of the wider nation.

Throughout 2005 Brash attacked Māori values generally and Labour for pandering to Māori. Brash described the powhiri used to greet international visitors as a "seminaked male, sometimes quite pale-skinned Maori [sic], leaping around in, you know, mock battle". 91 National was committed to abolishing the Māori seats and reviewing Te Puni Kōkiri, Office of the Māori Trustee, Te Māngai Pāho, the Waitangi Tribunal and the Office of Treaty Settlements - with expectations that the review would remove a number of these agencies. ${ }^{92}$ Labour was forced into defending powhiri, the Māori seats and various government agencies. ${ }^{93}$ Again the aim was to make Labour defend Māori rights and implied that Labour was more concerned with addressing Māori issues than Pākehā issues.

\footnotetext{
90 Quoted in: Ruth Berry, "National spreads short, sharp message," New Zealand Herald, http://www.nzherald.co.nz/section/1/story.cfm?c_id=1\&objectid=10328610, 2005 (accessed: 30 October 2007).

91 Quoted in: Amanda Spratt, "Too much culture, says Brash," New Zealand Herald, http://www.nzherald.co.nz/section/1/story.cfm?c_id=1\&ObjectID=10343937, $2005 \quad$ (accessed: 30 October 2007).

92 Ruth Berry, "Brash's knife hovers over Maori offices," New Zealand Herald, http://www.nzherald.co.nz/section/1/story.cfm?c_id=1\&objectid=10342927, 2005 (accessed: 30 October 2007).

${ }^{93}$ Berry, "Brash's knife hovers over Maori offices," ; Spratt, "Too much culture, says Brash,"
} 
Wedge tactics successfully served National in the 2005 campaign, but only up to a point. The Iwi/Kiwi billboard did grab attention, but it was pointed out that most of the uproar around the foreshore and seabed debate had come from Māori who were upset that the government was taking away, not giving, Māori rights. ${ }^{94}$ The Orewa speech was also attacked for having significant factual errors and 'teaching illusion' ${ }^{95}$ Indeed Colin James notes that National's stand on race issues meant that "Labour may owe as much as 1 to 2 percent of its final vote to adverse reaction to that position from liberal whites, from Maori [sic] and from Pacific Islanders." 96

National's multi-pronged 2005 election strategy was primarily devised by external consultants brought in specifically for winning the election. They produced a salesorientated campaign which focused on selling policy to traditional supporters, which had left National for other parties in 2002, rather than winning over new voters. ${ }^{97}$ For National to use these new strategies they needed a highly flexible organisation, with minimal or no internal resistance to the employment of such strategies. The 2003 reorganisation provided the degree of flexibility needed. Furthermore, the centralisation provided the money to hire professional consultants, such as Crosby|Textor, to recommend such strategies. While these new campaign strategies were introduced by the Party, more traditional methods also received a considerable boost from National's centralisation.

\footnotetext{
${ }^{94}$ Hager, The Hollow Men, 186.

95 Johansson, "Orewa and the Rhetoric of Illusion."

${ }^{96}$ Colin James, "A Contest of Values or a Contest of Wills? Factors and Issues in the 2005 Election," in Stephen Levine and Nigel S. Roberts (eds.), The Baubles of Office: The New Zealand General Election of 2005, (Wellington: Victoria University Press, 2007), 60.

${ }^{97}$ Jennifer Lees-Marshment, "Political Marketing," in Raymond Miller (ed.), New Zealand Government and Politics, (Melbourne: Oxford University Press, 2006), 495-496.
} 


\section{$\underline{\text { Consistent Advertising }}$}

National's 2005 advertising was more consistent throughout the country. Almost all advertising sought both the party and electorate vote. It was made clear to delegates at regional conferences by Steven Joyce and Judy Kirk that there was only to be one standardised campaign. ${ }^{98}$ The Party had standardised billboards and pamphlets. Television and radio campaigns were linked. The campaign team decided not to use newspaper advertising, instead allowing electorates to use that medium as their own.

National "made a clear decision not to have a newspaper advertising campaign." 99 The advertising that National did undertake in newspapers was based on the initiative of individual electorates rather than that of the National Management Board. Given the institutional view held by many volunteers within National that it was the electorate vote that mattered, ${ }^{100}$ it is not surprising that one-quarter of the newspaper adverts did not push for the party vote and none included a picture of Don Brash. ${ }^{101}$ The lack of central control over the newspaper campaign allowed electorates to present their own messaging in one medium which did not clash or contradict the central campaigns advertising in that medium.

\footnotetext{
${ }^{98}$ Rudd and Hayward, "Campaigning," 335.

${ }^{99}$ Emphasis in original. Chris Rudd, Scott Connew, Phil Harris, and Matthew Parackal, "Political Advertising in the Metropolitan Newspapers," in Stephen Levine and Nigel S. Roberts (eds.), The Baubles of Office: The New Zealand General Election of 2005, (Wellington: Victoria University Press, 2007), 202.

${ }^{100}$ See: Joyce, "National - The Road to Recovery," 109.

${ }^{101}$ Rudd, Connew, Harris, and Parackal, "Political Advertising in the Metropolitan Newspapers," 201203.
} 
National's 2005 billboard range was highly professional and standardised. The nationwide billboards were "breathtakingly simply.... clear and uncluttered" and were "probably unmatched in New Zealand electoral politics for 30 years." 102 National hired external consultant John Ansell to create the ideas for the billboards while Phil O'Reilly of 20/20 Design Group transformed them into billboards. ${ }^{103}$

\section{Figure 6.3 National Party 'Tax/Cut' Billboard ${ }^{104}$}

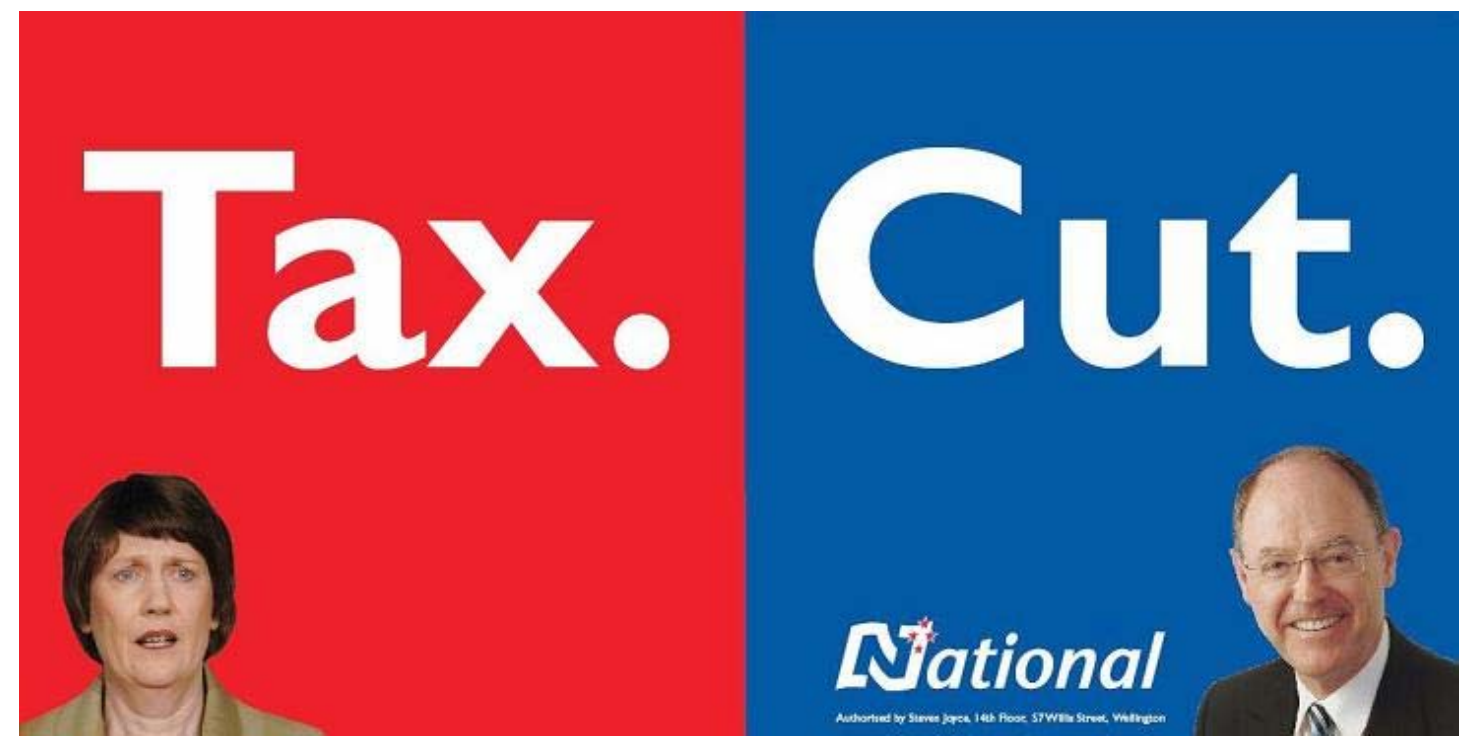

All of the nationwide billboards were split into two halves - the left half had a red background and a picture of a sour-looking Helen Clark; the right half had a blue background, a photo-shopped picture of smiling Don Brash and the National logo. Each half then had white words conveying policy differences. ${ }^{105}$ For instance, on one billboard (Figure 6.3) the Labour-side had the word 'Tax'; the National-side then had 'Cut' - the message being that Labour overtaxes voters whereas National will cut taxes.

\footnotetext{
${ }^{102}$ Nigel S. Roberts, "Changing Spots: Political Party Billboard Battles in New Zealand in 2005," in Stephen Levine and Nigel S. Roberts (eds.), The Baubles of Office: The New Zealand General Election of 2005, (Wellington: Victoria University Press, 2007), 270, 274.

${ }^{103}$ Hager, The Hollow Men, 183.

${ }^{104}$ Image from: New Zealand National Party, "Send An e-Card,"

${ }^{105}$ Roberts, "Changing Spots," 269-272.
} 
The billboards were so successful that the ACT Party copied the design by adding a yellow panel with a picture of Rodney Hide to the right-hand side. ${ }^{106}$ National used about 20 different billboards, although some were for specific events in order to appeal to a congregation of like-minded individuals (such as horse racing enthusiasts). ${ }^{107}$

The 2005 electorate billboards all followed a set pattern. On the left was a picture of the electorate candidate; on the right a picture of Don Brash - the same picture as on the nationwide billboards (although cropped slightly lower) to link the campaigns together. Between them (in descending order) were: the candidate's surname, the electorate name, 'PARTY VOTE' and finally 'National'. The billboards were clearly set out on the same blue background as the right-side of the nationwide billboards and successfully asked for both votes to go to National. Figure 6.4 shows Auckland Central candidate Pansy Wong's billboard and Wayne Mapp's North Shore billboard with a last-minute attachment, both of which followed the generic model.

Figure 6.4 National 2005 Electorates Billboards ${ }^{108}$

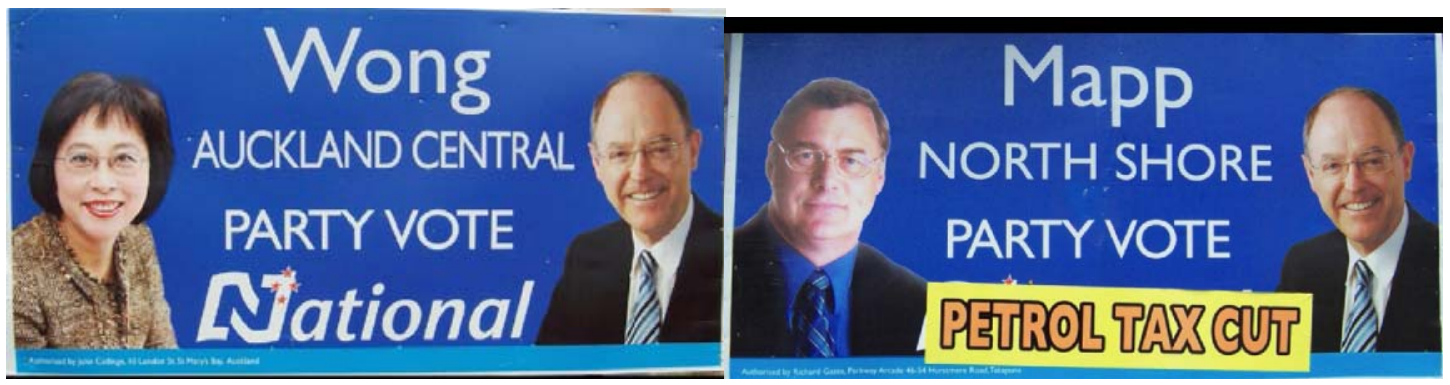

\footnotetext{
${ }^{106}$ Roberts, "Changing Spots," 277.

107 Joyce, "National - The Road to Recovery," 110.

${ }^{108}$ Both photos taken by Nigel S. Roberts who retains copyright. The photos were published in: Claire Robinson, "DVD," in Stephen Levine and Nigel S. Roberts (eds.), The Baubles of Office: The New Zealand General Election of 2005, (Wellington: Victoria University Press, 2007).
} 
While the nationwide billboards were controversial (especially the 'Iwi/Kiwi' billboard seen in Figure 6.2), they pushed National's party vote message successfully. The central control achieved by the National Management Board meant that electorate candidates were not solely seeking a personal vote but instead seeking 'two-ticks' for National. In previous election campaigns there had been an option of ordering billboards centrally, but in 2005 it "pretty much became a requirement to order centrally."109 Interestingly, the authorisation for the billboards still lay with the electorate - for instance Pansy Wong's billboard was authorised by John Collinge while Wayne Mapp's North Shore billboard received authorisation from Richard Gates (see Figure 6.4). In contrast, all Labour electorate billboards were authorised by General Secretary Mike Smith. ${ }^{110}$ However, although legal responsibility with the billboard still lay with the electorate, the design and messages were clearly controlled by the National Management Board.

In 2005 National had a more systematic central control over the material delivered to households. A nationwide pamphlet was designed by John Ansell and was distributed under the authorisation of Steven Joyce. The aim was to link the print material in with the nationwide television and radio campaign (see below). The nationwide 'Taxathon' pamphlets (see Figure 6.5) featured a picture of Helen Clark ('The Prime Moneywater') and Michael Cullen ('The Wastemaster-General') and then proceeded to list extra taxes Labour raised alongside a list of what National determined was embarrassing extra spending by the government. ${ }^{111}$ The 'Taxathon' pamphlets were distributed to almost

\footnotetext{
${ }^{109}$ Subject C, Interview.

110 To view the billboards, see: Robinson, "DVD."

111 Taylor, "New take on old jingle to push tax message,"
} 
one million households throughout the country. ${ }^{12}$ Another six pamphlets, as well as several postcard versions of the nationwide billboards, were distributed on a nationwide basis. $^{113}$

Figure 6.5 National 'Taxathon' Pamphlet ${ }^{114}$

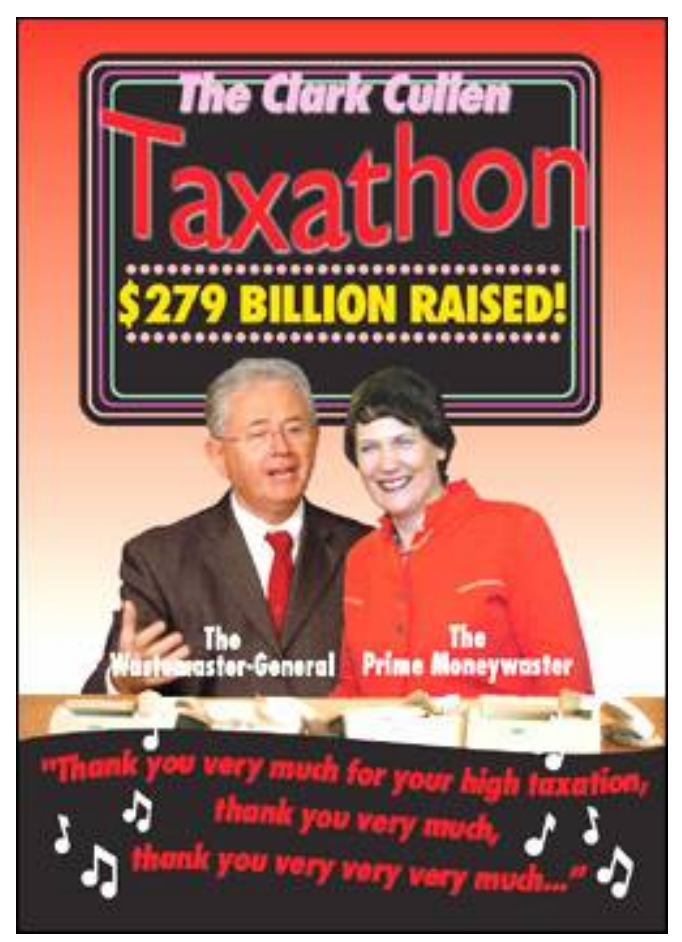

Electorates put out their own pamphlets as well - these were not coordinated nationally but did highlight the party vote. Officially the advertising on the pamphlet was split fifty-fifty between the party vote and electorate vote in order to share the spending under the Electoral Act 1993. The pamphlets were still aimed at raising candidate

\footnotetext{
112 Steven Joyce, "National to send out a million 'Taxathon' pamphlets," Scoop, http://www.scoop.co.nz/stories/PO0508/S00061.htm, 2005 (accessed: 31 October 2007).

${ }_{113}^{11}$ Joyce, "National - The Road to Recovery," 110.

${ }^{114}$ Image from: Kevin Taylor, "New take on old jingle to push tax message," New Zealand Herald, http://www.nzherald.co.nz/section/1/story.cfm?c_id=1\&objectid=10339261, 2005 (accessed: 31 October 2007).
} 
awareness, although the Party headquarters ensured they used consistent branding (such as the National logo) and sought both votes. ${ }^{115}$

Figure 6.6 Screenshots of National 'Taxathon' Television Advertisement ${ }^{116}$

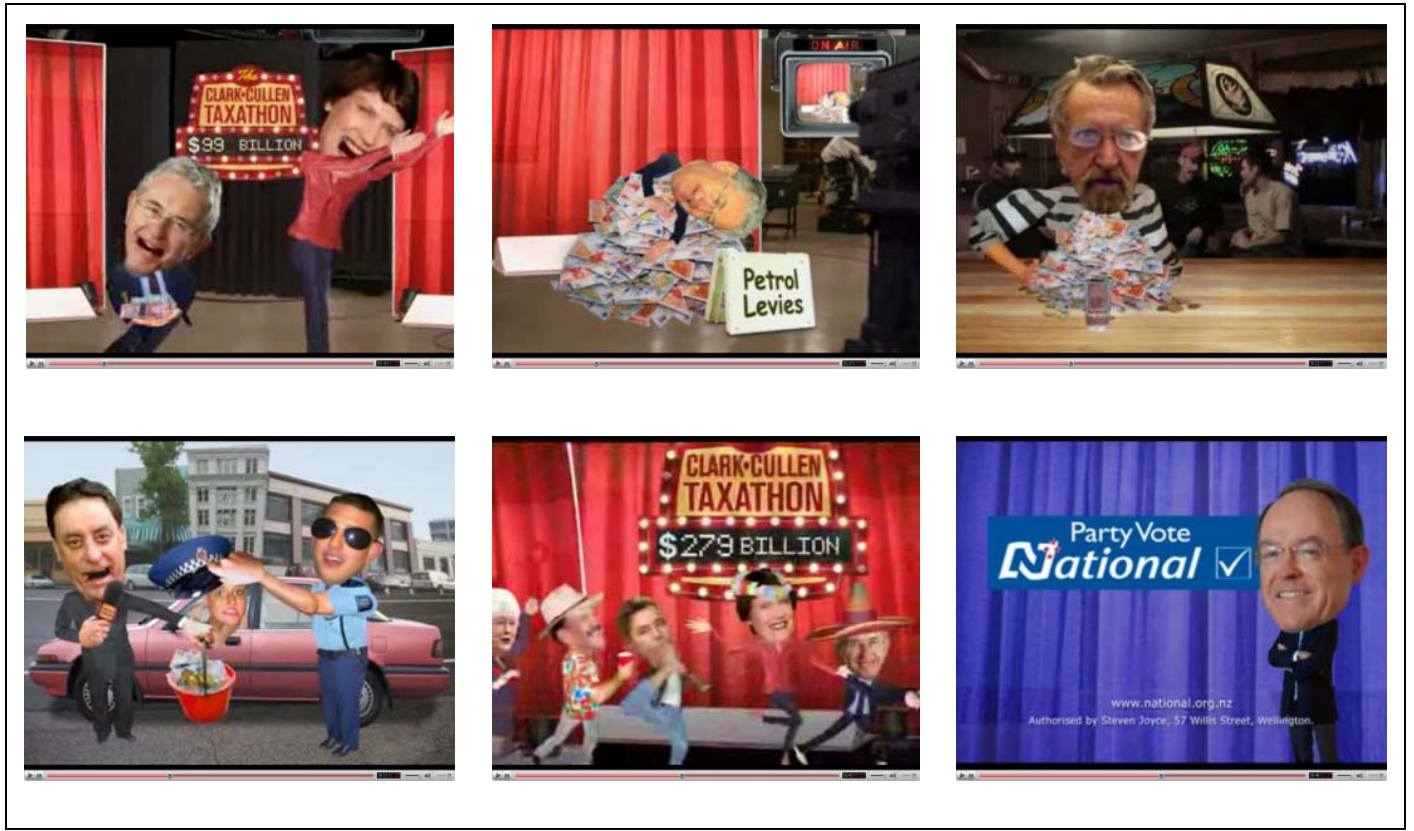

National's 2005 television and radio advertisements were strongly thematically linked together - as too was the main election pamphlet (see above). The main television advert National used was the 'Taxathon' (see Figure 6.6). The television campaign used the 'Telethon' jingle but with some new words; Helen Clark and Michael Cullen sung 'Thank you very much for you high taxation'. The advert went on to attack Labour on numerous grounds - education, personal scandals, new/higher taxes, and policing. Finally at almost the end of the advert the voiceover stated 'We have a new

\footnotetext{
115 Subject C, Interview.

${ }^{116}$ Images are screenshots from: New Zealand National Party, "The Great NZ Taxathon,"
} 
total. Time we had a new government' with Don Brash responding 'Thank you very much' in front of a blue background with 'PartyVote National' on it. ${ }^{117}$

Radio has not been a significant medium for the National Party. In 2005 electorates continued to use radio outside the ninety-day period in order to highlight the candidate - there was no central control over these advertisements. ${ }^{118}$ However, Steven Joyce's radio background led National to use radio advertising to work alongside its nationwide television and pamphlet campaign. The 2005 radio 'Taxathon' advertisments were primarily the music and lyrics from the television adverts.

Television and radio advertising were both more professionalised in the 2005 campaign. John Ansell designed the television, radio and pamphlet campaigns. Indeed, advertising initiatives had significantly improved in regard to all mediums used in the campaign, bar newspapers. Almost all of the nationwide advertising focused either on areas on which liberals and conservatives agreed - lower tax, ending government waste and so forth - or were dog-whistles and wedges.

While there was some resistance to the centralised control, electorates did follow the directives of the National Management Board. With the vastly superior advertising of the 2005 election campaign, alongside new strategies and more money to spend, National was able to secure 39.1 percent of the party vote.

\footnotetext{
117 New Zealand National Party, "The Great NZ Taxathon," New Zealand National Party, http://www.national.org.nz/files/Taxathon_small.asf, 2005 (accessed: 24 October 2007).

${ }^{118}$ Subject C, Interview.
} 


\section{$\underline{\text { The } 2005 \text { Election }}$}

The 2005 election produced significantly different results from previous MMP elections. National grew its vote share. The campaign itself was seen as being highly successful compared to previous MMP elections:

It was probably the first campaign I've been involved in since ' 87 where no one bitched about the campaign afterwards - this is incredibly rare, as I said you have a party of 20,000 experts and I've not heard any serious criticism. $^{119}$

Labour still had the advantage going into the campaign - a booming economy, a significantly larger caucus to send out on the campaign trail, Helen Clark was well ahead in preferred Prime Minister polling - and won two percent more of the party vote. The 2002 election result still hurt National in the 2005 campaign:

[T] he election result was a case of 'If I was trying to go there, I wouldn't start from here'. It is hard to impress as an alternative government with only 27 MPs out of a Parliament of 120 , and the support resources to match. As a result of the 2002 election, the National political team was woefully small compared to the resources the Labour government could bring to bear, and that led to too many cracks. ${ }^{120}$

While the centralisation had many positive impacts for National, it also meant that in 2005 the Party suffered from a lack of institutional knowledge on the ground:

That institutional knowledge was pretty good at the regional level, we've lost that, and that was one of the prices we paid, and we're yet to find a formula, we're yet to replace it at the national level. I think we're getting

\footnotetext{
${ }^{119}$ Subject C, Interview.

${ }^{120}$ Joyce, "National - The Road to Recovery," 113.
} 
there, we're getting underway for the long-term good of the Party. ${ }^{121}$

The campaign strategy that National ran ensured that it almost doubled its previous election result and was within two percent of Labour's result. National actually won 802 more electorate votes than Labour throughout the country, although both parties secured 31 electorate seats.

Figure 6.7 Straight-Ticket Voting for the National Party, 1996-2005 ${ }^{122}$

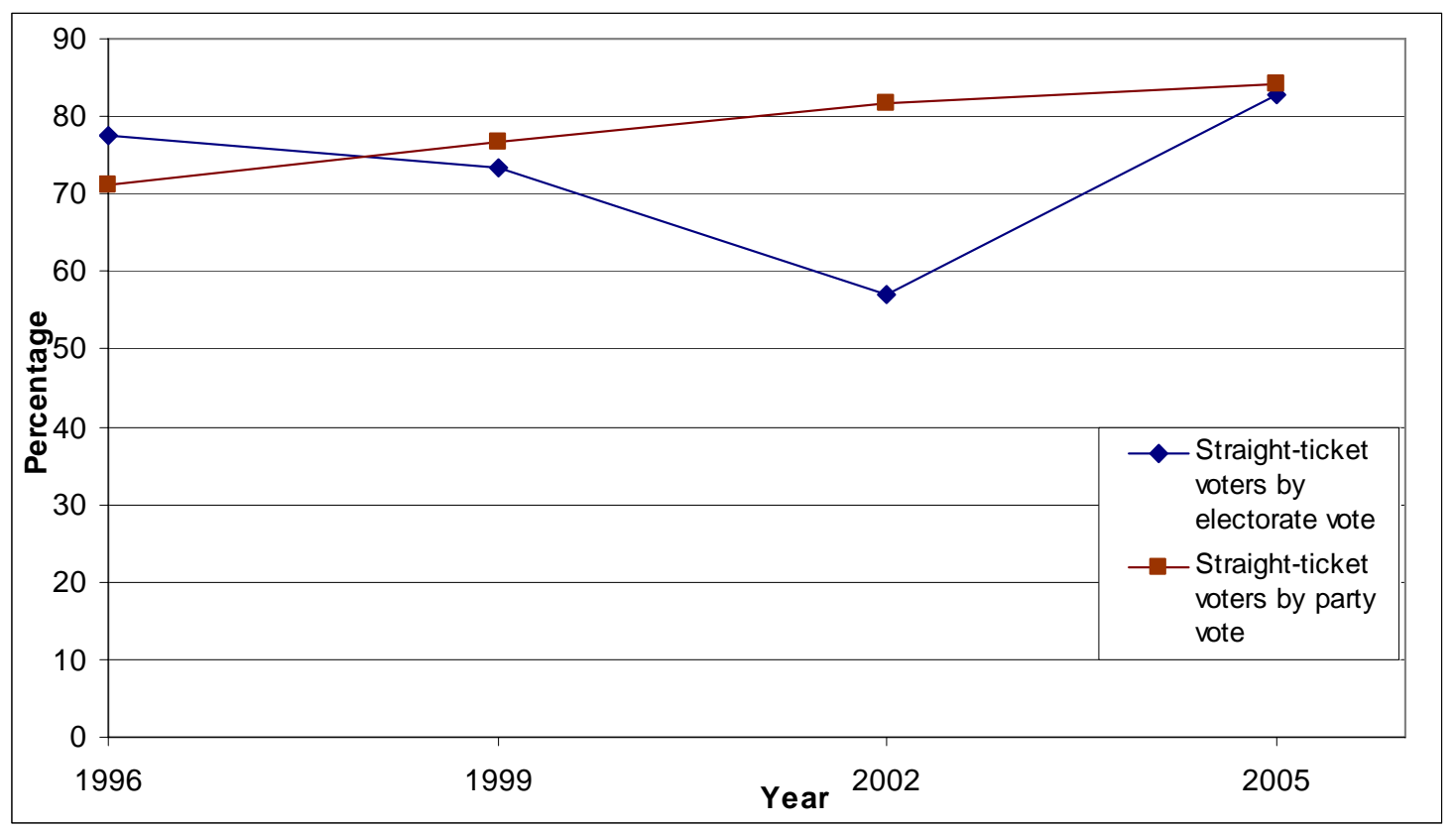

Split-ticket voting significantly fell in 2005. In the 1996, 1999 and 2002 elections, National was unable to convert all electorate-vote voters into party-vote voters (see

${ }^{121}$ Subject B, Interview.

122 The 1996 data is from survey data: Levine and Roberts, "Surveying the Snark," 185-186. The 1999 data is calculated from: Jack Vowles, "What Happened at the 1999 Election?," in Jack Vowles, Peter Aimer, Jeffrey Karp, Susan Banducci, Raymond Miller, and Ann Sullivan (eds.), Proportional Representation on Trial: The 1999 New Zealand General Election and the Fate of MMP, (Auckland: Auckland University Press, 2002), 88. The 2002 and 2005 data has been calculated from official results from: Chief Electoral Office, "2002 General Election Split Voting Statistics," Elections New Zealand, http://2002.electionresults.govt.nz/splitvotes/excel/SplitVotingAllElectorates.xls, 2002 (accessed: 10 December 2007); Chief Electoral Office, "2005 General Election Split Voting Statistics - All Electorates," Elections New Zealand, http://2005.electionresults.govt.nz/elect-splitvote-Overall.html, 2005 (accessed: 10 December 2007). 
Figure 6.7). In 2002 only 57.1 percent of those giving National their electorate vote went on to give National a party vote. In contrast, 82.9 percent of those giving their electorate vote to National also gave their party vote to National in 2005. The substantial increase in terms of electorate voters giving National their party vote indicates that in 2005 National was able to convert electorate support into party votes more effectively through a party vote focused campaign. As Figure 6.8 shows, National decline had largely been in the party vote; the electorate vote in 2002 was not significantly below that of the previous election.

Figure 6.8 National Valid Vote Share $1990-2005^{123}$

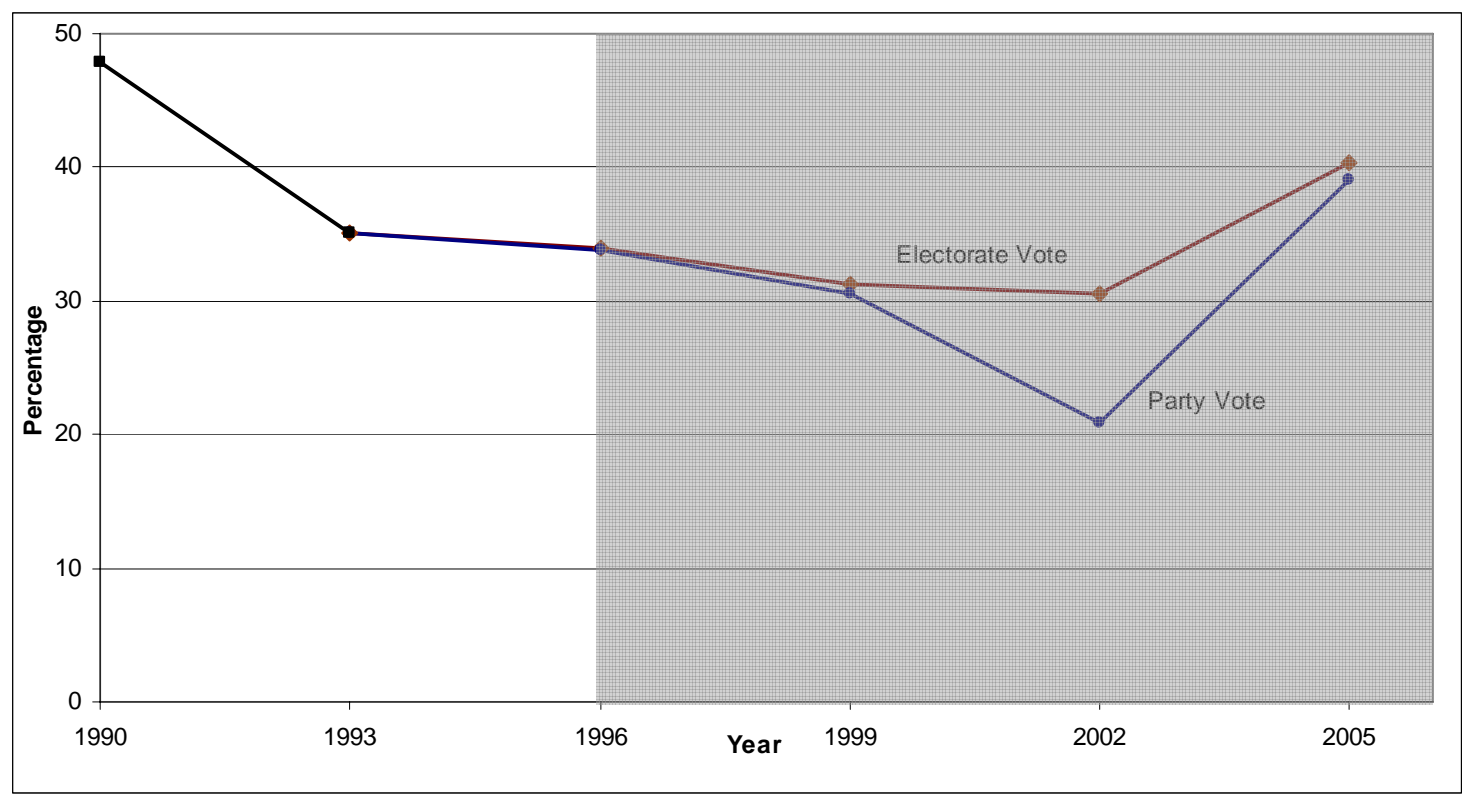

National's recovery was not evenly distributed throughout the country. As a result of promises by National to reduce the number of civil servants, the Wellington Central seat swung towards Labour. Northland swung slightly towards Labour largely, it seems, as a result of Shane Jones being selected as Labour's candidate. While National

${ }^{123}$ Electoral Commission, "General elections 1890-1993," ; Electoral Commission, "General elections 1996-2005," 
won the plurality in the general seats, the Māori seats swung to National by just 0.06 percent of the party vote, and meant National did not receive the overall plurality. National won the North Island general electorates by 42.1 percent to Labour's 39.5 percent. Yet Labour won the South Island by 42.4 percent to National's 39.2 percent. Women comprised only 46 percent of National's voters. The campaigning, and the candidates selected, did not have enough nationwide appeal. ${ }^{124}$

National's new campaign strategies also had significant impacts on other political parties. ACT was largely decimated and only remained in Parliament due to National voters splitting their ticket in Epsom, against the wishes of the National Party, by giving their electorate vote to Rodney Hide. ${ }^{125} \mathrm{ACT}$ also lost the significant financial donations from large corporations and wealthy individuals, as well as political advertiser John Ansell. United Future was reduced to just three MPs. New Zealand First lost a significant number of voters and the Tauranga electorate, placing New Zealand First in a precarious position for following elections.

Steven Joyce noted that the centralisation "became the first building blocks of the party’s 2005 election campaign." 126 The re-organisation created new opportunities for the Party. It became easier for National to collect corporate donations, to seek the advice of professional campaigners, to use new and controversial tactics and to run a nationwide campaign. These new strategies and opportunities were all taken up in the

\footnotetext{
${ }^{124}$ Stephen Levine and Nigel S. Roberts, "The Baubles of Office: Winning and Losing Under MMP," in Stephen Levine and Nigel S. Roberts (eds.), The Baubles of Office: The New Zealand General Election of 2005, (Wellington: Victoria University Press, 2007), 31-48.

${ }^{125}$ Rodney Hide, "ACT - Survival in Epsom," in Stephen Levine and Nigel S. Roberts (eds.), The Baubles of Office: The New Zealand General Election of 2005, (Wellington: Victoria University Press, 2007), 141-142.

${ }^{126}$ Joyce, "National - The Road to Recovery," 105.
} 
2005 election campaign and all had significant impact on the way in which National campaigned throughout the country. National was able to convert supporters into voters more effectively due to its new organisation. The centralised organisation was better to suited to the MMP environment than the previous decentralised organisation. 


\section{Chapter Seven: Conclusion}

The New Zealand National Party underwent dramatic events in the 1990s and 2000s. The period started well for National - under Jim Bolger National won a landslide FPP election after six years in opposition at the 1990 election. Soon, however, the Party faced serious difficulty. National barely won the 1993 election and only because Labour and the Alliance divided the Left vote. The 1996 election, the first under the new MMP electoral system, again saw National scrape back in to government - this time in a coalition with New Zealand First. After a leadership change to Jenny Shipley and the collapse of the coalition, National lost office at the 1999 election. The party changed its leader again, this time to Bill English, only to fall dramatically at the 2002 election to just 20.9 percent of the party vote.

This catalogue of defeats prompted changes which resulted in National winning 39.1 percent in the 2005 election - not enough to get National into government, but almost double the 2002 result. After the 2002 election result, the Party accepted that something was seriously wrong and embarked upon a number of changes. First, Judy Kirk replaced Michelle Boag as Party President. Then, National reviewed its structures and, after finding them wanting, re-organised itself into a leaner, more centralised party. Leader Don Brash replaced Bill English, promising corporate donations and expertise. However, the most significant change, which affected the power balances, was the internal restructuring. This new centralised structure was the main reason National was finally able to produce an MMP campaign in 2005. 


\section{Electoral Systems and Party Organisation}

National's decline and climb is, at least partially, an organisational story. The decentralised organisation served National well under FPP and allowed it to win the majority of elections in which the Party competed. The new MMP electoral system raised challenges which the decentralised organisation could not cope with. Instead National entered into a decline. The Party re-organised itself into a centralised party that was better able to operate in the MMP environment.

Internationally there has been a common trend for parties to centralise their activities due to decline, infighting or cartelisation. ${ }^{1} \quad$ The alternative explanations for centralisation need to be ruled out for National. Parties have tended to respond to vote share decline through centralisation. However National's decline was primarily not due to weak leadership, a lack of voter trust, social change or economic change - thereby ruling out that it was a response to a 'normal' decline. Further, parties have been reformed as part of infighting within the party. Yet there is little evidence to suggest that the re-organisation was an attempt by one group of elites to takeover the entire party, indeed one rule change ensured Board turnover rather than entrench their positions. $^{2}$ Another potential explanation for a centralisation is that it is the cartelisation of National. Yet other cartel model reforms were not attempted, and National rejected state funding after it was proposed by Labour. ${ }^{3}$

\footnotetext{
${ }^{1}$ See Chapter Two.

2 See: New Zealand National Party, "Constitution and Rules (2003)," 21.

3 Judy Kirk, "National Party President Perspective" (paper presented at the Funding of Political Parties and Election Campaigns Symposium, Wellington, 15 June 2007).
} 
National's centralisation was a response to changes in the electoral system under which the Party operated. While postulating general rules and laws from one case is folly, the experience of the National Party does provide clues for further comparative analysis. The hypotheses proposed earlier were:

Hypothesis 1: In competitive environments, political parties require an organisation which is suited to the environment in which they operate in.

Hypothesis 2: MMP requires a more centralised organisation than FPP.

Hypothesis 2.1: A Shift from FPP to MMP is likely to produce a centralisation of candidate selection and campaigning.

The National Party provides a single-case analysis which supports these hypotheses. Under FPP, National did have an organisation which was suited to its environment, and National won office more times than any other party. The environment changed with the introduction of MMP and National's organisation was no longer suited to its environment. National did change its organisation to make it better suited to MMP, and did so by centralising its governance, candidate selection and campaign management. The experience of National, at least, confirms the hypothesis that mixed member proportional favours a more centralised organisation than first-past-the-post is correct. National was more successful when it brought campaign control and candidate selection more under the control of the National Management Board.

The changes to National arguably meant that the New Zealand National Party was less democratic internally. Party members lost control over the Board and the presidency, over candidate selection, and over the campaign strategy. However, National cannot be blamed for its decision to re-organise itself along arguably less democratic lines. One 
of the key goals of National is to win office - they wished to reclaim the title of 'the natural party of government'. If that means that the elites have greater control, then for many members that is more than a worthwhile exchange. In terms of democracy within New Zealand, the question is was the exchange of internal party democracy for greater inter-party democracy worth while?

\section{Future Challenges for National}

National formed in an environment in which there was significant pressure for a twoparty system. However under MMP, the smaller, ideologically purer parties are better able to compete for specific voters than one broad-church hybrid party. National is surrounded by other parties and changing policy simply opens up room for other parties to gain voters. While in 2005 National was able to build a coalition of liberal and conservative voters, it is a long-term challenge for each and every election for National.

National could split itself into two political parties. The liberal faction, with some ACT members, would form one distinct political party. The conservative faction, with some New Zealand First and United Future members, would form the other centre-Right party within New Zealand. As Figure 7.1 shows, the parties would meet in the centreground and then each seek out their own distinctive set of voters. The liberal party would range from social to economic liberals and predominately target urban areas; while the conservative party would focus upon conservative issues and be linked with the farming community. 
Figure 7.1 New Zealand Political Spectrum with National Split into Separate Liberal and Conservative Parties ${ }^{4}$

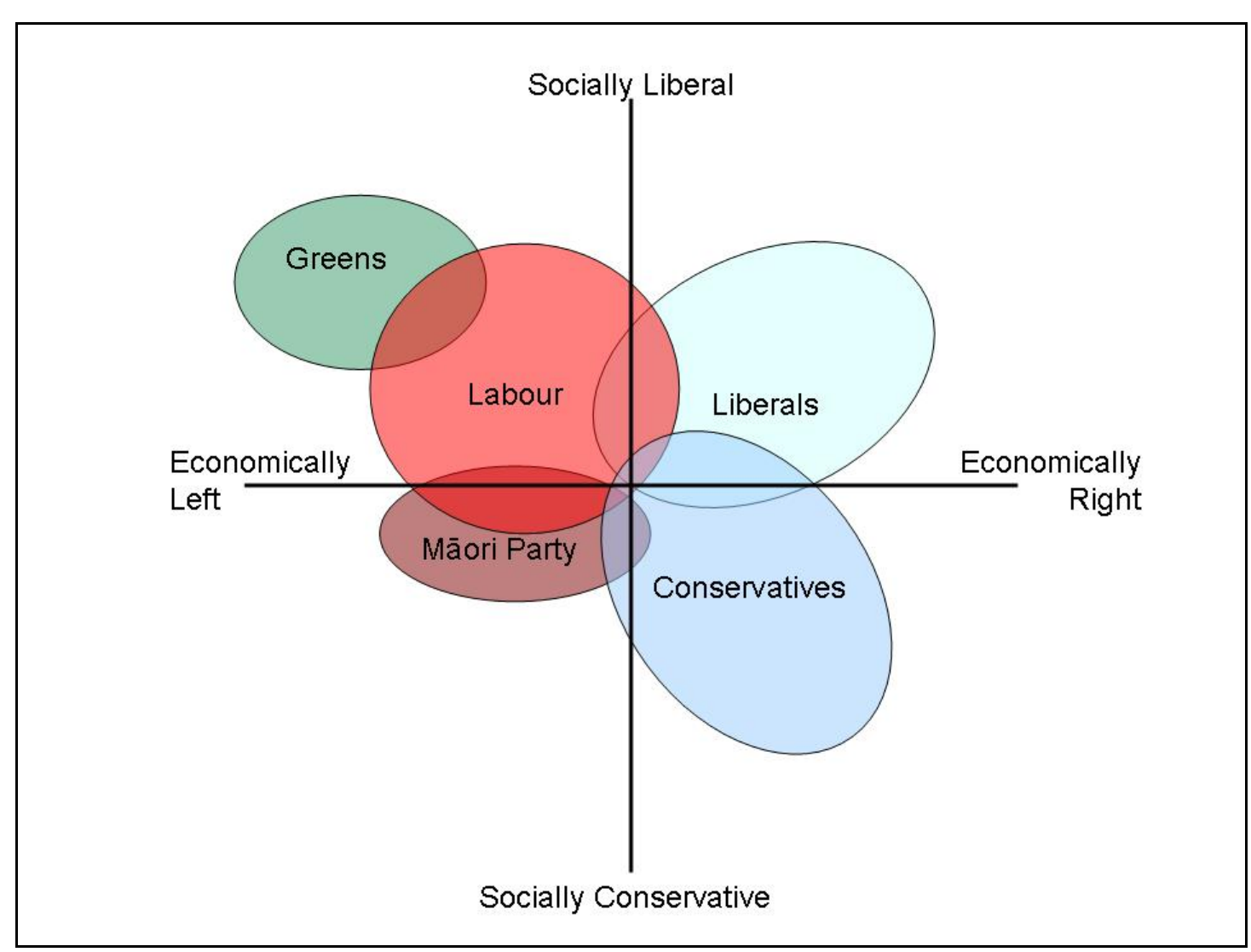

With the Duvergerian pressure on National gone, National will need to address this challenge of whether it is better to have a liberal-conservative coalition within one party or between two parties. Each system has advantages and disadvantages. The 2003 reorganisation did not address the ideological divide found within National. The divide may cause potential problems in the future for National. The lack of need for a liberalconservative alliance in one political party is a potential future challenge that National may need to address.

\footnotetext{
${ }^{4}$ The Progressive Coalition and all non-parliamentary parties are excluded. Party size indicates ideological range, not vote share. Compare with Figure 4.5 for the post-2002 political spectrum (which excludes the Māori Party).
} 


\section{Conclusion}

The 2003 changes substantially altered National and made it more suited to the new electoral system. While the National Management Board gained control in campaigning, candidate selection was only partially centralised. National's structure will continue to be reviewed to ensure that it is suited to its environment. There is likely to be an attempt to further centralise the candidate selection process, and it may be the final change to respond to electoral reform. Any other changes brought forward are unlikely to be a response to electoral reform, but to other changes in the internal or external environment.

Ultimately the New Zealand National Party was a response to the organisational demands of first-past-the-post. Its organisation was established in that environment to compete in elections. The Party began to decline under mixed member proportional electoral rules and only a significant centralisation helped it to recover in the 2005 election. The change to mixed member proportional led National to centralise its organisational structure. The pressure for parties to centralise is indeed stronger under mixed member proportional than under first-past-the-post. 


\section{Appendix One: Organisation and Candidate Selection Charts}

The following charts are designed as visual aids of organisation. They do invariably result in simplifying the relationships and do not indicate how each stage is determined. However, they do provide a useful guide to be read alongside the various editions of the Constitution and Rules of the New Zealand National Party.

\section{Notes:}

- The 1995-2003 candidate selection chart is based upon the post-1997 reform rules. There were three minor changes impacting on the process.

o In 1996 the Young Nationals were represented on the List Standing Committee by the Young Nationals Chairperson. From 1997 onwards the Young Nationals were represented by the Youth Vice President.

o In 1996 the National Treasurer was involved in candidate selection through his/her position on the National Executive.

o In 1996 the central body is known as the 'National Executive'. From 1997 onwards it is known as the 'National Management Board'.

- No account is made for how each stage progresses.

- No account is made for the different powers each body or person has.

- Selection by a collection of different persons/groups is indicated by a bordered box around those people with an arrow from the box itself.

- Lines are coloured with the colour of the box that the line flows to. However, parliamentary candidates are found in brown throughout.

- Colours are kept constant through the graphs for the same, or similar, body.

- Nominations are in dotted-lines.

- The choice of colour does not represent any judgement value whatsoever. 


\section{5-1997 Organisation}

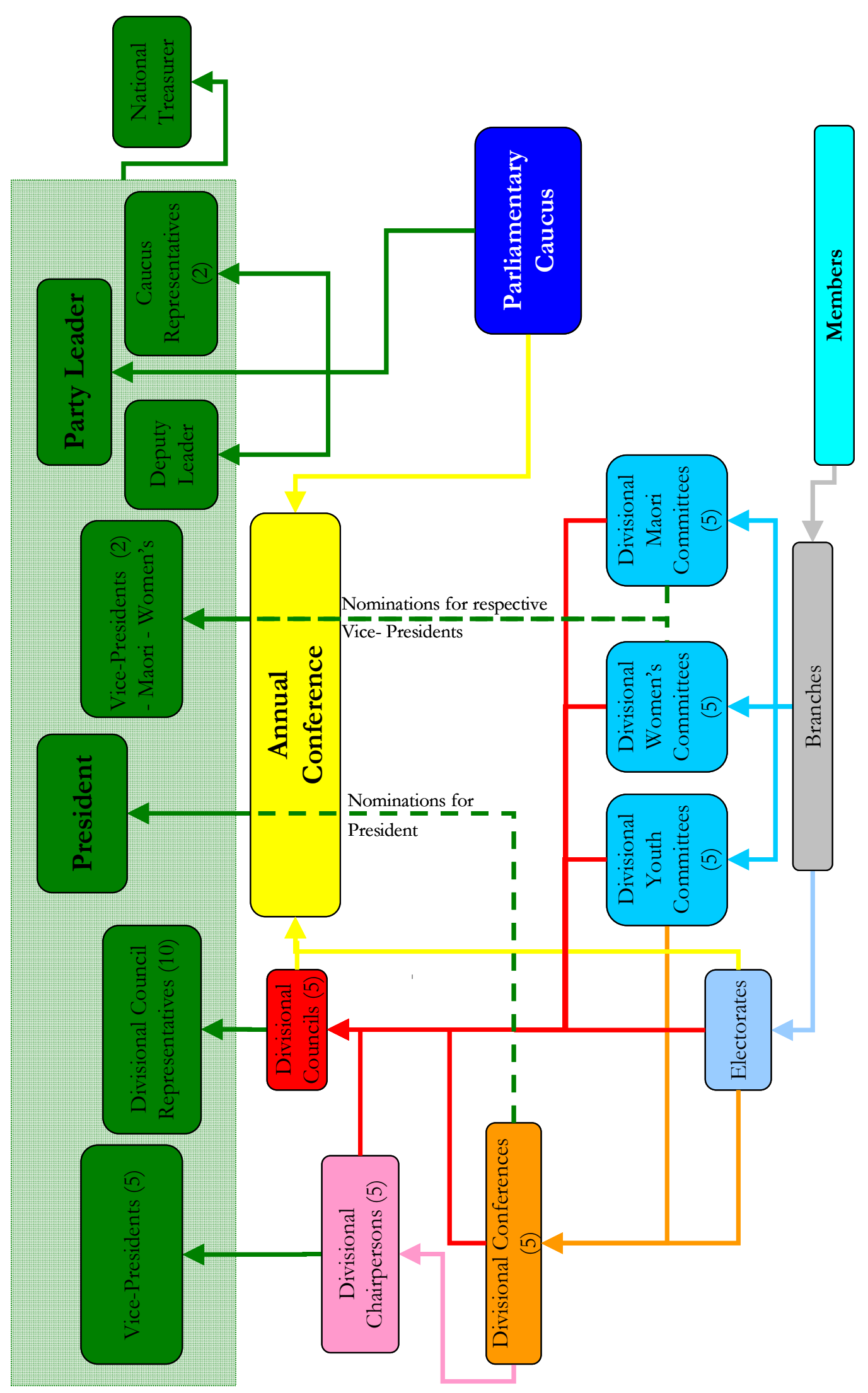




\section{7-2003 Organisation}

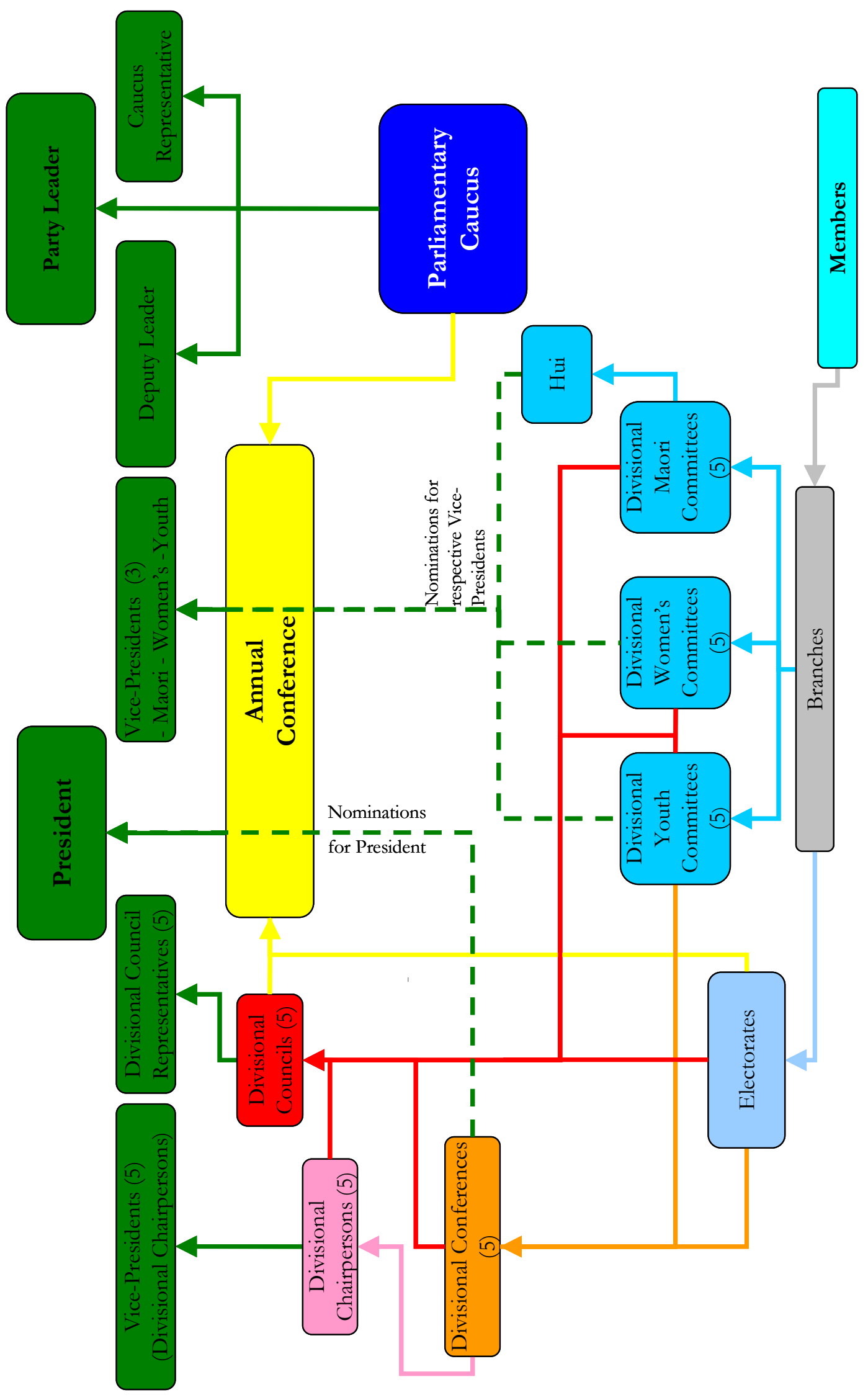




\section{3- Organisation}

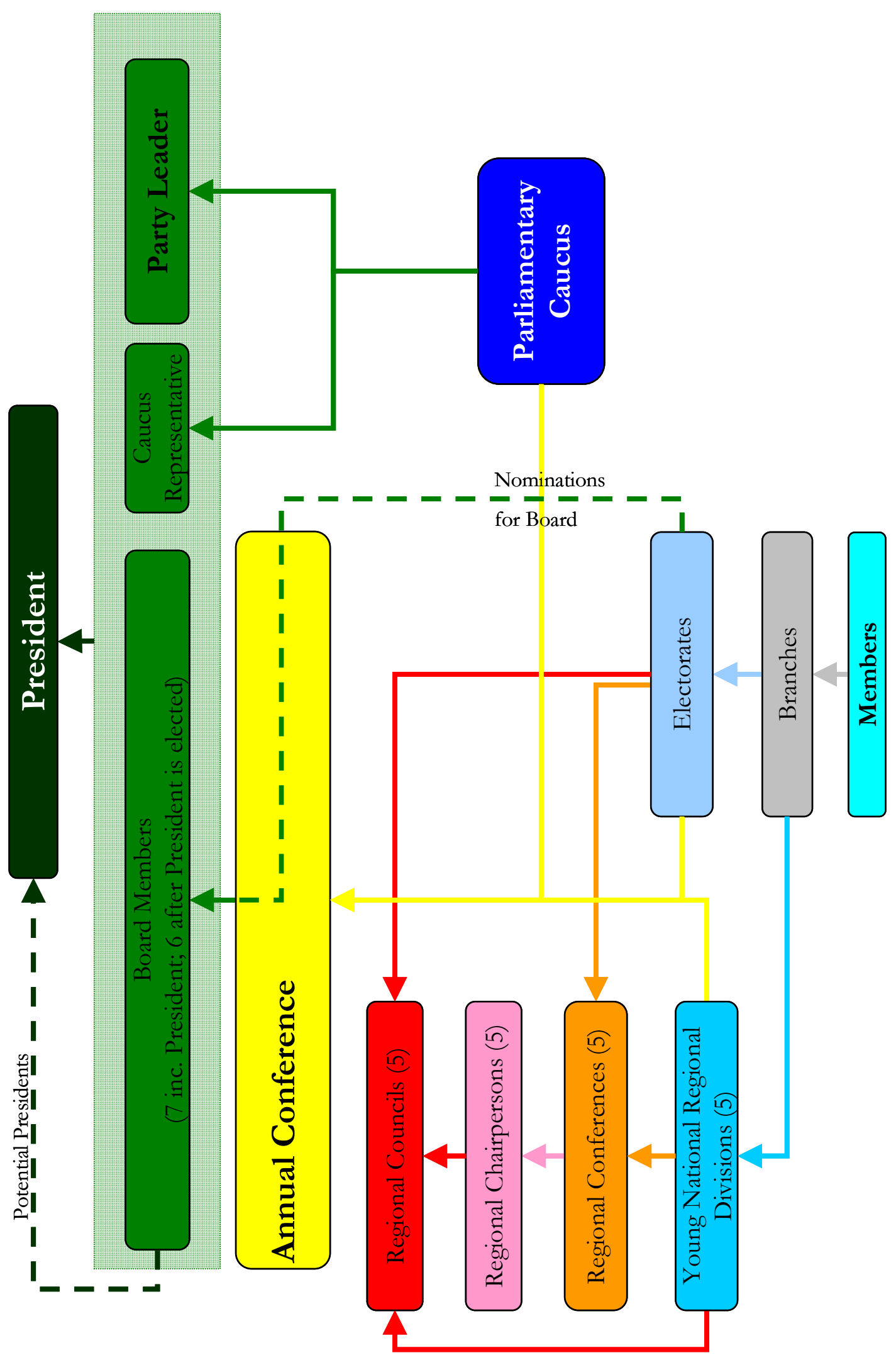




\section{3-1995 Candidate Selection}

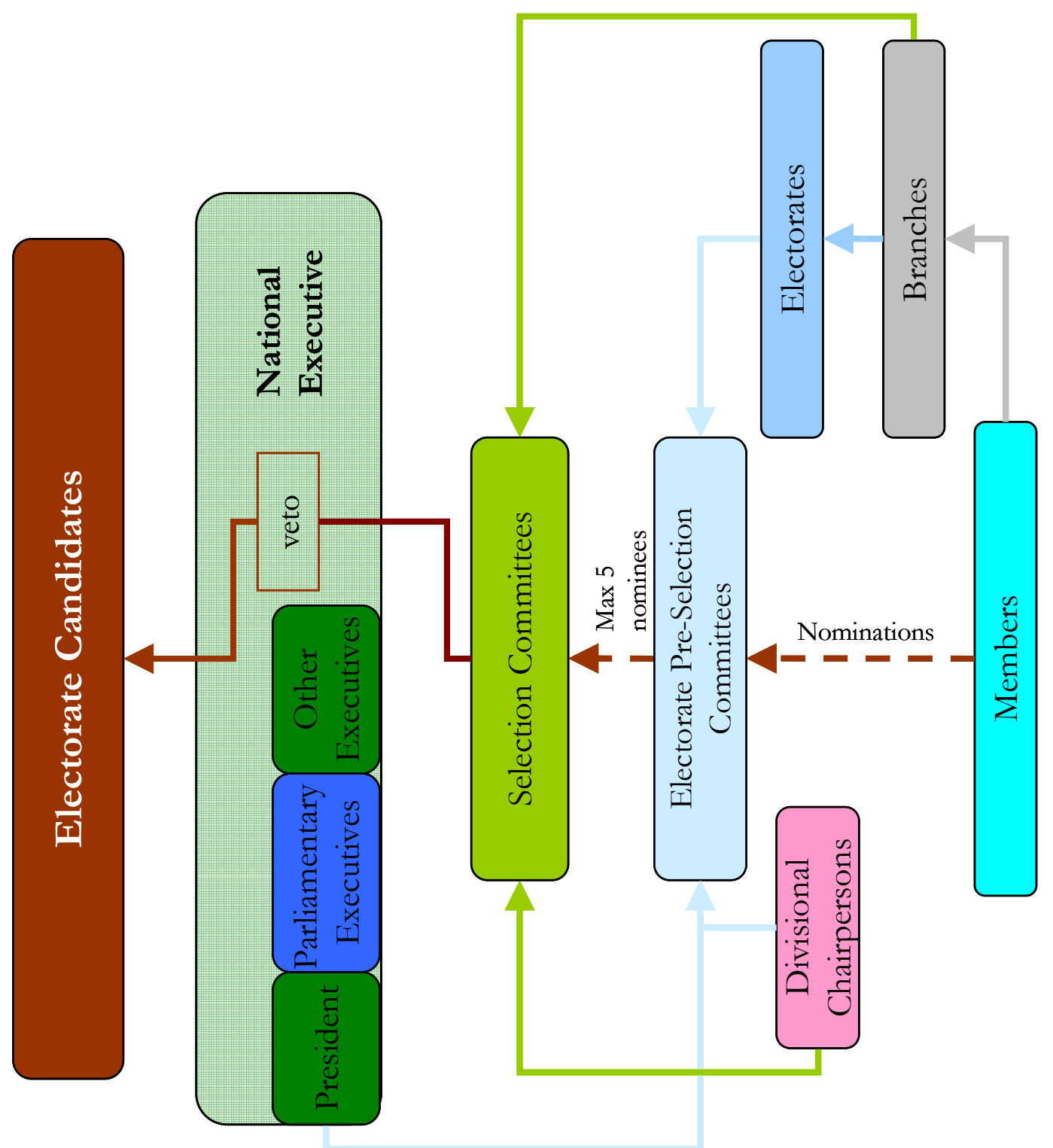




\section{5-2003 Candidate Selection}

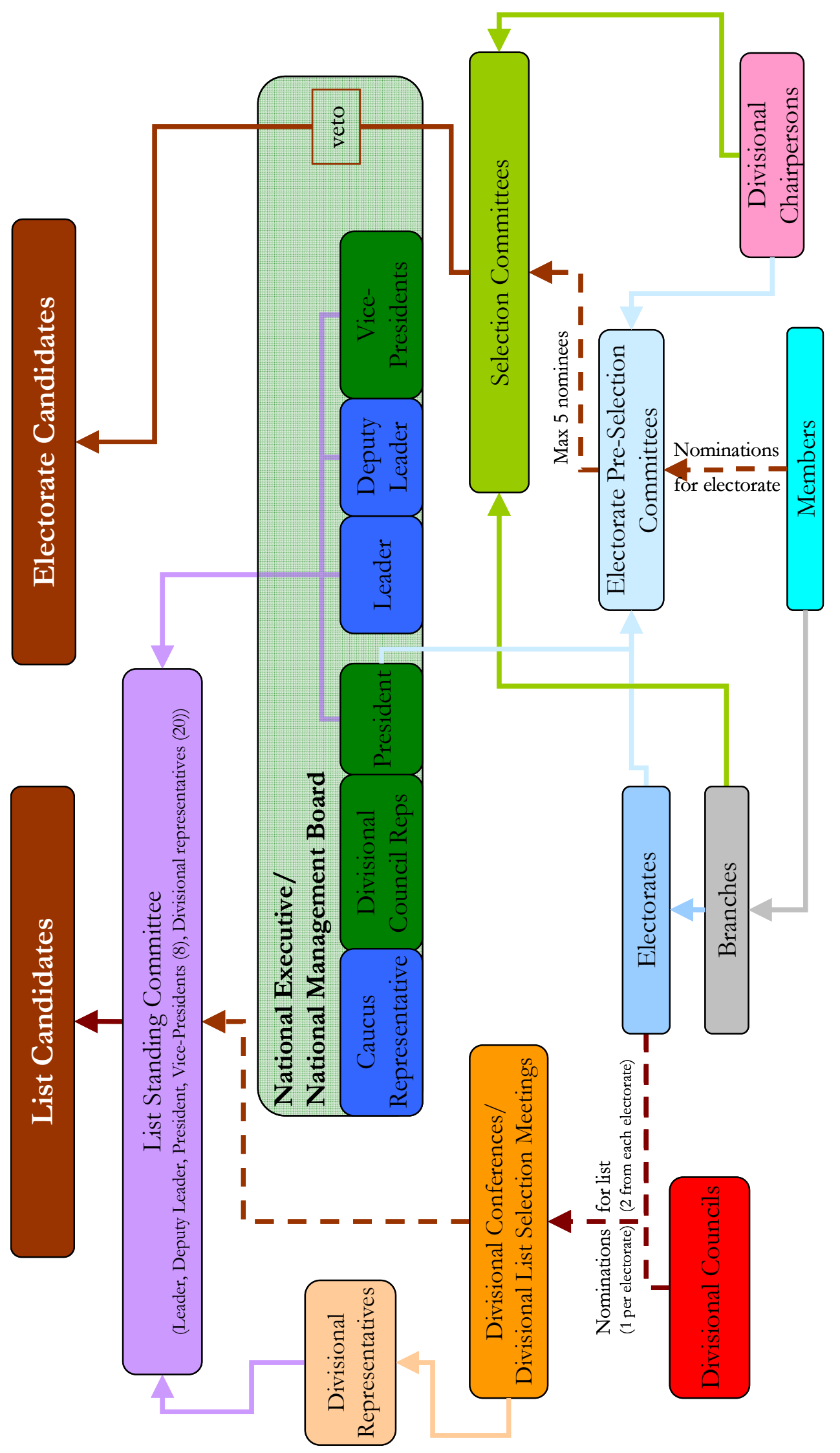




\section{3- Candidate Selection}

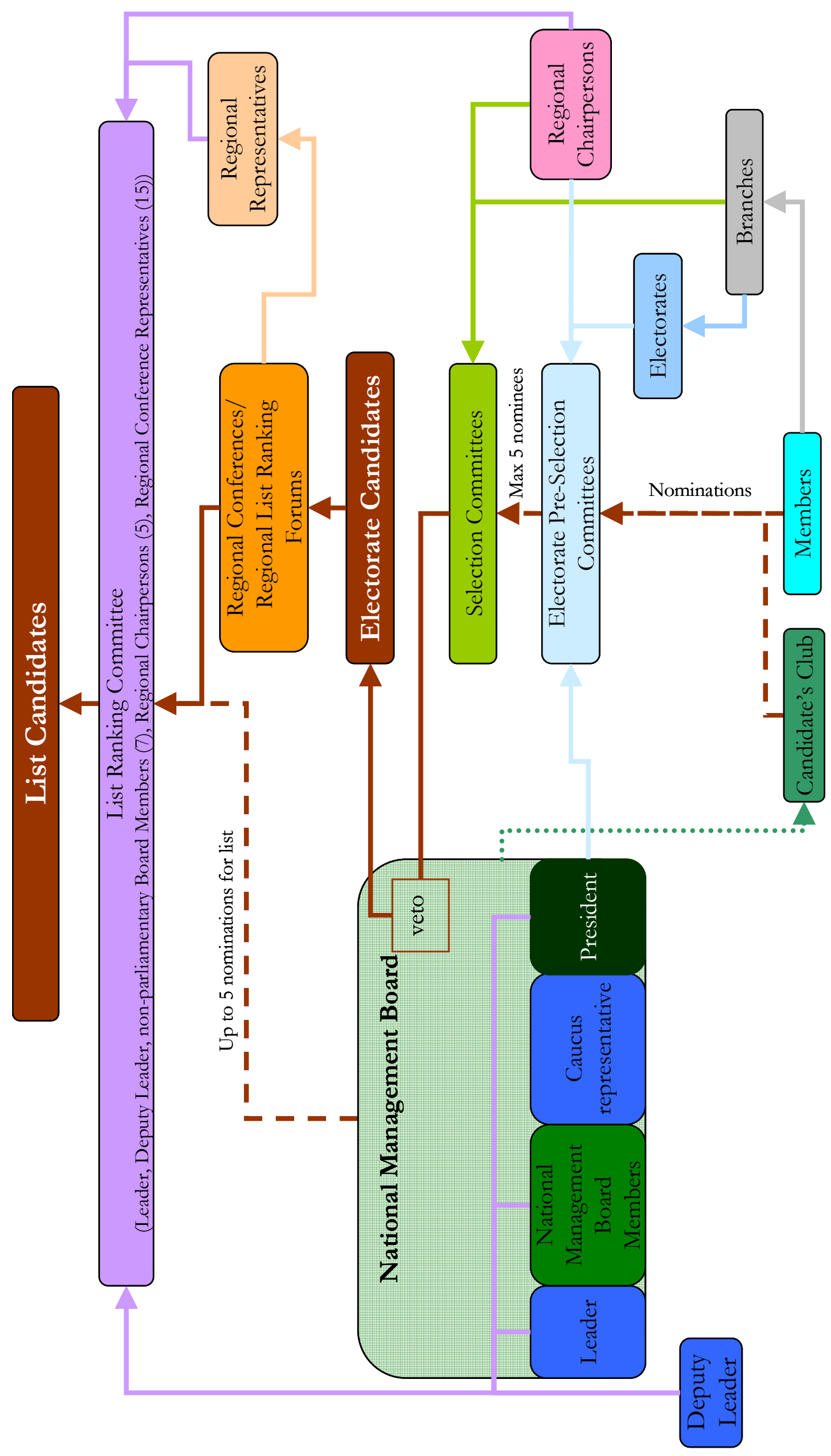




\section{Appendix Two: National Party Candidates 1996-2005}

Losing candidates (on election night) are in italics. If the electorate is italicised, but not the candidate, then it indicates the candidate came in on the list and lost the electorate. No ranking indicates that the candidate was not on the list.

\section{Election}

The National Party candidate pool for 1996 was:

\begin{tabular}{|c|c|c|}
\hline List Ranking & Candidate & Electorate \\
\hline 1 & Jim Bolger & Taranaki-King Country \\
\hline 2 & Don McKinnon & \\
\hline 3 & Bill Birch & Port Waikato \\
\hline 4 & Jenny Shipley & Rakaia \\
\hline 5 & Paul East & \\
\hline 6 & Doug Graham & \\
\hline 7 & Georgina te Heuheu & \\
\hline 8 & Lockwood Smith & Rodney \\
\hline 9 & Bill English & Clutha-Southland \\
\hline 10 & Katherine O'Regan & Tauranga \\
\hline 11 & Simon Upton & \\
\hline 12 & Wyatt Creech & Wairarapa \\
\hline 13 & Joy McLauchlan & Hutt South \\
\hline 14 & Doug Kidd & Kaikoura \\
\hline 15 & Roger Sowry & Otaki \\
\hline 16 & John Banks & Whangarei \\
\hline 17 & Jim Gerard & Waimakariri \\
\hline 18 & Belinda Vernon & Maungakiekie \\
\hline 19 & Arthur Anae & \\
\hline 20 & Maurice Williamson & Pakuranga \\
\hline 21 & Murray McCully & Albany \\
\hline 22 & Christine Fletcher & Epsom \\
\hline 23 & Eric Roy & Invercargill \\
\hline 24 & Peter Gresham & Whanganui \\
\hline 25 & Roger Maxwell & New Plymouth \\
\hline 26 & Pansy Wong & \\
\hline 27 & Marie Hasler & Waitakere \\
\hline 28 & Annabel Young & \\
\hline 29 & Tony Ryall & Bay of Plenty \\
\hline 30 & Nick Smith & Nelson \\
\hline 31 & Alec Neill & \\
\hline 32 & Denis Marshall & Rangitikei \\
\hline 33 & John Luxton & Karapiro \\
\hline 34 & John Carter & Northland \\
\hline 35 & Brian Neeson & Waipareira \\
\hline 36 & Ian Revell & Northcote \\
\hline 37 & Wayne Taitoko & \\
\hline
\end{tabular}




\begin{tabular}{|c|c|c|}
\hline 38 & David Major & Rongotai \\
\hline 39 & Margie Stevens & Dunedin North \\
\hline 40 & Warren Kyd & Hunua \\
\hline 41 & David Carter & Banks Peninsula \\
\hline 42 & Clem Simich & Tamaki \\
\hline 43 & Lindsay Tisch & \\
\hline 44 & Tony Steel & Hamilton East \\
\hline 45 & Bob Simcock & Hamilton West \\
\hline 46 & Phil Raffils & Owairaka \\
\hline 47 & Gerry Brownlee & Ilam \\
\hline 48 & Karyn Bisdee & Rimutaka \\
\hline 49 & Mark Thomas & Wellington Central \\
\hline 50 & Shane Frith & Auckland Central \\
\hline 51 & Margaret Moir & West Coast - Tasman \\
\hline 52 & Paul Hutchinson & \\
\hline 53 & Angus McKay & Wigram \\
\hline 54 & Stuart Boag & Aoraki \\
\hline 55 & Dick Dargaville & Te Tai Tokerau \\
\hline 56 & Peta Butt & Te Tai Rawhiti \\
\hline 57 & Gavan Herlihy & Otago \\
\hline 58 & Wayne Mapp & North Shore \\
\hline 59 & Wayne Kimber & Mahia \\
\hline 60 & Graeme Reeves & Tukituki \\
\hline 61 & Sue McKenzie & Christchurch East \\
\hline 62 & George Matthew & Palmerston North \\
\hline 63 & Cliff Bedwell & Te Tai Tonga \\
\hline 64 & Ken Yee & Manukau East \\
\hline \multirow[t]{12}{*}{65} & Kathryn Ward & Napier \\
\hline & Max Bradford & Rotorua \\
\hline & Murray McLean & Coromandel \\
\hline & David Broome & Mangere \\
\hline & Richard Gardner & New Lynn \\
\hline & Malcolm MacPherson & Dunedin South \\
\hline & Les Marinkovich & Manurewa \\
\hline & John McCarthy & Taupo \\
\hline & Tahuna Minhinnick & Te Tai Hauauru \\
\hline & Kerry Sutherland & Christchurch Central \\
\hline & Timoti te Heuheu & Te Puku O Te Whenua \\
\hline & Allan Wells & Mana \\
\hline
\end{tabular}

No National candidate was stood in Ohariu-Belmont. 


\section{Election}

The National Party candidate pool for 1999 was:

\begin{tabular}{|c|c|c|}
\hline List Ranking & Candidate & Electorate \\
\hline 1 & Jenny Shipley & Rakaia \\
\hline 2 & Wyatt Creech & \\
\hline 3 & Don McKinnon & \\
\hline 4 & Bill English & Clutha-Southland \\
\hline 5 & Lockwood Smith & Rodney \\
\hline 6 & Georgina te Heuheu & \\
\hline 7 & Roger Sowry & Otaki \\
\hline 8 & Nick Smith & Nelson \\
\hline 9 & Tony Ryall & Bay of Plenty \\
\hline 10 & Belinda Vernon & Maungakiekie \\
\hline 11 & Pansy Wong & \\
\hline 12 & Simon Upton & \\
\hline 13 & Maurice Williamson & Pakuranga \\
\hline 14 & John Luxton & \\
\hline 15 & Max Bradford & Rotorua \\
\hline 16 & John Carter & Northland \\
\hline 17 & Doug Kidd & \\
\hline 18 & Annabel Young & \\
\hline 19 & Eric Roy & Invercargill \\
\hline 20 & Anne Tolley & Napier \\
\hline 21 & David Carter & Banks Peninsula \\
\hline 22 & Bob Simcock & Hamilton West \\
\hline 23 & Katherine Rich & Dunedin North \\
\hline 24 & Marie Hasler & Titirangi \\
\hline 25 & Arthur Anae & \\
\hline 26 & Alec Neill & \\
\hline 27 & Katherine O'Regan & Tauranga \\
\hline 28 & Mark Thomas & Mana \\
\hline 29 & Phil Raffills & Mt Roskill \\
\hline 30 & Kerry Prendergast & \\
\hline 31 & Martin Poulsen & Auckland Central \\
\hline 32 & Gavan Herlihy & Otago \\
\hline 33 & Wayne Mapp & North Shore \\
\hline 34 & Brian Neeson & Waitakere \\
\hline 35 & Shane Ardern & Taranaki-King Country \\
\hline 36 & Gerry Brownlee & Ilam \\
\hline 37 & Simon Power & Rangitikei \\
\hline 38 & Paul Hutchison & Port Waikato \\
\hline 39 & David Steele & Taupo \\
\hline 40 & Dale Stephens & Ikaroa-Rawhiti \\
\hline 41 & Angus McKay & Wigram \\
\hline 42 & Phil Heatley & Whangerei \\
\hline 43 & Paul Henry & Wairarapa \\
\hline
\end{tabular}




\begin{tabular}{|c|c|c|}
\hline 44 & Richard Worth & Epsom \\
\hline 45 & Chester Borrows & Whanganui \\
\hline 46 & George Ngatai & Waiariki \\
\hline 47 & Enosa Auva'a & Manurewa \\
\hline 48 & Rea Wikaira & \\
\hline 49 & Bret Bestic & \\
\hline 50 & Rod O'Beirne & West Coast - Tasman \\
\hline 51 & Wayne Marriott & Aoraki \\
\hline 52 & Stephen Rainbow & \\
\hline 53 & Tim MacIndoe & \\
\hline 54 & George Kahi & Hauraki \\
\hline 55 & Larry White & Tukituki \\
\hline 56 & Ken Yee & Manakau East \\
\hline 57 & Lynda Scott & Kaikoura \\
\hline 58 & Matthew Parkinson & East Coast \\
\hline 59 & Dawn Honeybun & \\
\hline 60 & George Halligan & Palmerston North \\
\hline 61 & Grant McCallum & \\
\hline 62 & Peggy Burrows & \\
\hline 63 & Toni Millar & \\
\hline 64 & Noelene Buckland & Mt Albert \\
\hline \multirow[t]{20}{*}{65} & Stuart Boag & Rongotai \\
\hline & Warren Kyd & Hunua \\
\hline & Murray McCully & Albany \\
\hline & Clem Simich & Tamaki \\
\hline & Tony Steel & Hamilton East \\
\hline & Lindsay Tisch & Karapiro \\
\hline & Gideon Couper & Waimakariri \\
\hline & Len Jury & New Plymouth \\
\hline & Russell Keast & Dunedin South \\
\hline & John Knox & Christchurch East \\
\hline & Murray McLean & Coromandel \\
\hline & Vanessa Neeson & Te Atatu \\
\hline & Clare Radomkse & Hutt South \\
\hline & Ian Revell & Northcote \\
\hline & Stuart Roddick & Rimutaka \\
\hline & John Stringer & Christchurch Central \\
\hline & Sylvia Taylor & Mangere \\
\hline & Dennis Patuwairua & Te Tai Hauauru \\
\hline & Tom Murray & Te Tai Tokerau \\
\hline & Cliff Bedwell & Te Tai Tonga \\
\hline
\end{tabular}

Rea Wikaira (48) was not on the list given to the Electoral Commission.

No National candidates were stood in Ohariu-Belmont or Wellington Central 


\section{Election}

The National Party candidate pool for 2002 was:

\begin{tabular}{|c|c|c|}
\hline List Ranking & Candidate & Electorate \\
\hline 1 & Bill English & Clutha-Southland \\
\hline 2 & Roger Sowry & Otaki \\
\hline 3 & Nick Smith & Nelson \\
\hline 4 & David Carter & Banks Peninsula \\
\hline 5 & Don Brash & \\
\hline 6 & Georgina Te Heuheu & \\
\hline 7 & Wayne Mapp & North Shore \\
\hline 8 & Tony Ryall & Bay of Plenty \\
\hline 9 & Gerry Brownlee & Ilam \\
\hline 10 & Pansy Wong & Auckland Central \\
\hline 11 & Lockwood Smith & Rodney \\
\hline 12 & Lynda Scott & Kaikoura \\
\hline 13 & Simon Power & Rangitikei \\
\hline 14 & Katherine Rich & Dunedin North \\
\hline 15 & Hekia Parata & Wellington Central \\
\hline 16 & Gavan Herlihy & Otago \\
\hline 17 & Bob Simcock & Hamilton West \\
\hline 18 & Allan Peachey & \\
\hline 19 & Sue Wood & Mana \\
\hline 20 & Guy Salmon & \\
\hline 21 & John Carter & Northland \\
\hline 22 & Alec Neill & Wigram \\
\hline 23 & Belinda Vernon & Maungakiekie \\
\hline 24 & Anne Tolley & Napier \\
\hline 25 & Richard Worth & Epsom \\
\hline 26 & Eric Roy & Invercargill \\
\hline 27 & Paul Hutchison & Port Waikato \\
\hline 28 & Arthur Anae & Manukau East \\
\hline 29 & Ian Buchanan & Wairarapa \\
\hline 30 & Greg White & Te Tai Hauauru \\
\hline 31 & Phil Heatley & Whangarei \\
\hline 32 & Marie Hasler & Waitakere \\
\hline 33 & Annabel Young & \\
\hline 34 & Eric Liu & \\
\hline 35 & Tau Henare & Te Atatu \\
\hline 36 & Chester Borrows & Whanganui \\
\hline 37 & Nicky Wagner & Christchurch Central \\
\hline 38 & Leanne Jensen-Daines & East Coast \\
\hline 39 & Tim MacIndoe & Tauranga \\
\hline 40 & Wayne Marriott & Aoraki \\
\hline 41 & Dan Gordon & Waimakariri \\
\hline 42 & Sandra Goudie & Coromandel \\
\hline 43 & John Key & Helensville \\
\hline
\end{tabular}




\begin{tabular}{|c|c|c|}
\hline 44 & Jeremy Sole & Northcote \\
\hline 45 & George Ngatai & Tamaki Makaurua \\
\hline 46 & Dale Stephens & Ohariu-Belmont \\
\hline 47 & Craig Foss & Tukituki \\
\hline 48 & Judith Collins & Clevedon \\
\hline 49 & Glenda Hughes & Rongotai \\
\hline 50 & Dave Scott & Palmerston North \\
\hline 51 & Weston Kirton & Taupo \\
\hline 52 & Hamuera Mitchell & Waiariki \\
\hline 53 & Enosa Auva'a & Manurewa \\
\hline 54 & Sylvia Taylor & Mangere \\
\hline 55 & Barry Nicolle & West Coast - Tasman \\
\hline 56 & Paul Foster & Dunedin South \\
\hline 57 & Mita Harris & Te Tai Tokerau \\
\hline 58 & Brent Trewheela & Mt Roskill \\
\hline 59 & Raewyn Bhana & Mt Albert \\
\hline 60 & Bill Karaitiana & Te Tai Tonga \\
\hline 61 & Geoff Horton & New Plymouth \\
\hline 62 & Rodney Williams & \\
\hline 63 & Alan Delamere & Ikaroa-Rawhiti \\
\hline 64 & Peter O'Brien & \\
\hline \multirow[t]{15}{*}{65} & Rod O'Beirne & \\
\hline & Shane Ardern & Taranaki-King Country \\
\hline & Brian Connell & Rakaia \\
\hline & Murray McCully & East Coast Bays \\
\hline & Clem Simich & Tamaki \\
\hline & Lindsay Tisch & Piako \\
\hline & Maurice Williamson & Pakuranga \\
\hline & Brendan Beach & New Lynn \\
\hline & Cliff Bedwell & Te Tai Tonga \\
\hline & Kevin Davies & Tainui \\
\hline & Stephen Johnston & Christchurch East \\
\hline & Mike Leddy & Rimutaka \\
\hline & Tony Steel & Hamilton East \\
\hline & Malcolm Short & Rotorua \\
\hline & Richard Townley & Hutt South \\
\hline
\end{tabular}




\section{Election}

The National Party candidate pool for 2005 was:

\begin{tabular}{|c|c|c|}
\hline List Ranking & Candidate & Electorate \\
\hline 1 & Don Brash & \\
\hline 2 & Gerry Brownlee & Ilam \\
\hline 3 & Simon Power & Rangitikei \\
\hline 4 & Bill English & Clutha-Southland \\
\hline 5 & Nick Smith & Nelson \\
\hline 6 & Tony Ryall & Bay of Plenty \\
\hline 7 & John Key & Helensville \\
\hline 8 & David Carter & Banks Peninsula \\
\hline 9 & Lockwood Smith & Rodney \\
\hline 10 & Katherine Rich & Dunedin North \\
\hline 11 & Murray McCully & East Coast Bays \\
\hline 12 & Judith Collins & Clevedon \\
\hline 13 & Tim Groser & \\
\hline 14 & Wayne Mapp & North Shore \\
\hline 15 & John Carter & Northland \\
\hline 16 & Richard Worth & Epsom \\
\hline 17 & Maurice Williamson & Pakuranga \\
\hline 18 & Clem Simich & Mangere \\
\hline 19 & Georgina te Heuheu & \\
\hline 20 & Pansy Wong & Auckland Central \\
\hline 21 & Shane Ardern & Taranaki-King Country \\
\hline 22 & Phil Heatley & Whangarei \\
\hline 23 & Paul Hutchison & Port Waikato \\
\hline 24 & Lindsay Tisch & Paiko \\
\hline 25 & Brian Connell & Rakaia \\
\hline 26 & Sandra Goudie & Coromandel \\
\hline 27 & Chris Finlayson & Mana \\
\hline 28 & Nicky Wagner & Christchurch Central \\
\hline 29 & Tau Henare & Te Atatu \\
\hline 30 & Allan Peachey & Tamaki \\
\hline 31 & Jo Goodhew & Aoraki \\
\hline 32 & David Bennett & Hamilton East \\
\hline 33 & Chester Borrows & Whanganui \\
\hline 34 & Chris Auchinvole & West Coast - Tasman \\
\hline 35 & Jonathan Coleman & Northcote \\
\hline 36 & Mark Blumsky & Wellington Central \\
\hline 37 & Eric Roy & Invercargill \\
\hline 38 & Kate Wilkinson & Waimakariri \\
\hline 39 & Nathan Guy & Otaki \\
\hline 40 & Jacqui Dean & Otago \\
\hline 41 & Jackie Blue & Mt Roskill \\
\hline 42 & Colin King & Kaikoura \\
\hline 43 & Anne Tolley & East Coast \\
\hline
\end{tabular}




\begin{tabular}{|l|l|l|}
\hline 44 & Craig Foss & Tukituki \\
\hline 45 & Paula Bennett & Waitakere \\
\hline 46 & Katrina Shanks & Ohariu-Belmont \\
\hline 47 & Fepulea'i Ulua'ipou-OMa Aiono & Manurewa \\
\hline 48 & Ravi Musuku & Mt Albert \\
\hline 49 & Bob Clarkson & Tauranga \\
\hline 50 & John Hayes & Wairarapa \\
\hline 51 & Moira Irving & New Plymouth \\
\hline 52 & Chris Tremain & Napier \\
\hline 53 & Mita Harris & New Lynn \\
\hline 54 & Mike Leddy & Rimutaka \\
\hline 55 & Conway Powell & Dunedin South \\
\hline 56 & David Round & Christchurch East \\
\hline 57 & Gilbert Stehbens & Rotorua \\
\hline 58 & Ken Yee & Manukau East \\
\hline 59 & Paul Goldsmith & Maungakeikei \\
\hline 60 & Malcolm Plimmer & Palmerston North \\
\hline 61 & Nicola Young & Rongotai \\
\hline 62 & Tim MacIndoe & Hamilton West \\
\hline 63 & Allison Lomax & Wigram \\
\hline 64 & Weston Kirton & Taupo \\
\hline 65 & Rosemarie Thomas & Hutt South \\
\hline
\end{tabular}

No National candidates were stood in the following seats:

Ikaroa-Rawhiti

Tainui

Tamaki Makaurau

Te Tai Hauauru

Te Tai Tokerau

Te Tai Tonga

Waiariki 


\section{Appendix Three: Estimated Number of Party Members}

No formal membership figures are released, but there are a number of estimates made on the size of National's membership.

\section{Long-term trend, 1936-2007}

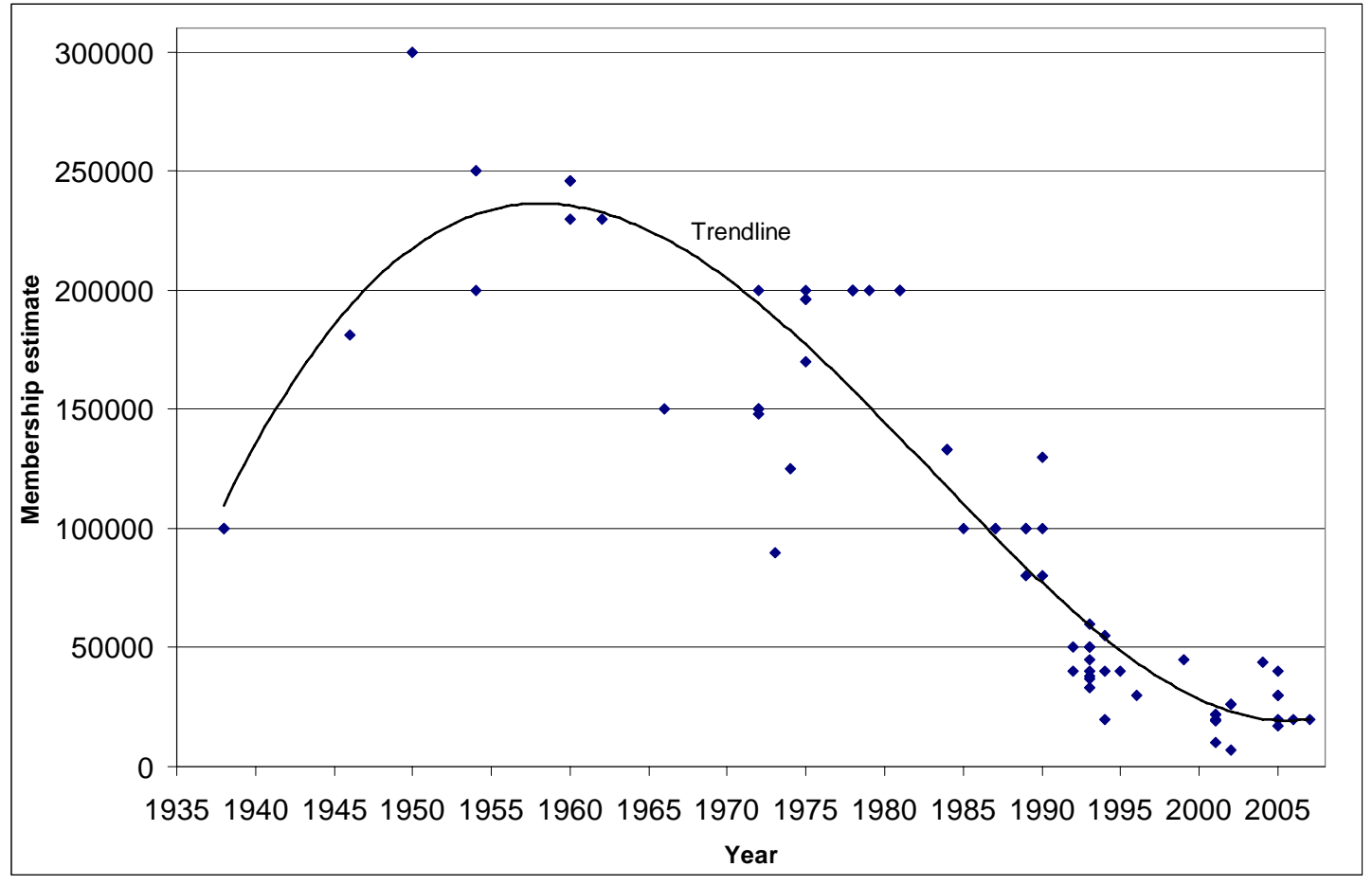

\section{Recent trend, 1990-2007}

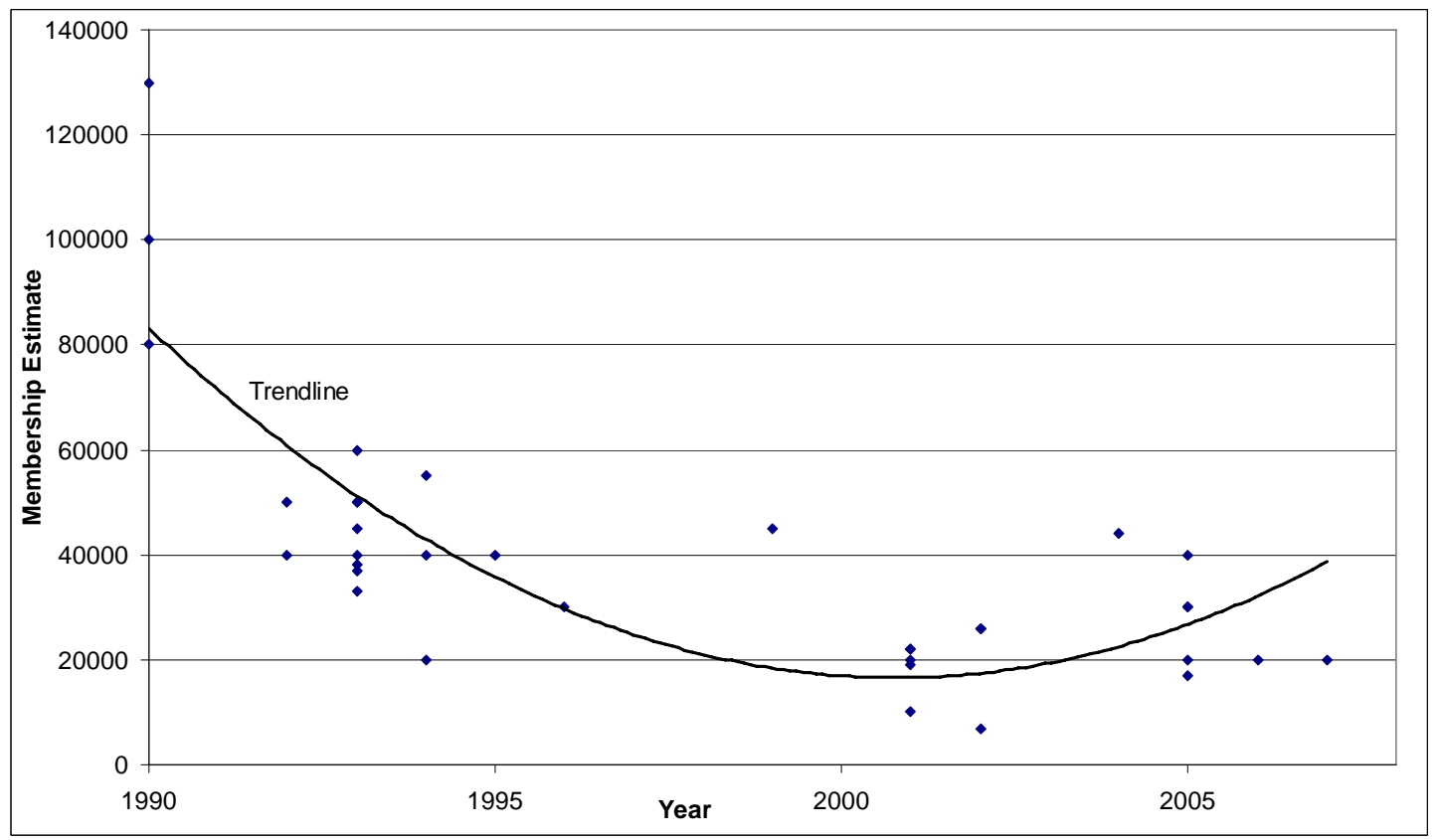




\section{Sources}

Most of the data is collated in:

Edwards, Bryce, "Political Parties in New Zealand: A Study of Ideological and Organisational Transformation" (PhD, University of Canterbury, 2003). 397, 689-691

However, this has been supplemented by some more recent estimates, from:

\begin{tabular}{|c|c|c|}
\hline Year & Estimate & Source \\
\hline $\begin{array}{l}1940 \mathrm{~s} \\
\text { and } \\
1950 \mathrm{~s}\end{array}$ & 300,000 & $\begin{array}{l}\text { Miller, Raymond, Party Politics in New Zealand (Melbourne: } \\
\text { Oxford University Press, 2005). } 73\end{array}$ \\
\hline $\begin{array}{l}\text { Early } \\
1970 \mathrm{~s}\end{array}$ & 200,000 & $\begin{array}{l}\text { James, Colin, "National," in Raymond Miller (ed.), New } \\
\text { Zealand Government and Politics. (Auckland: Oxford } \\
\text { University Press, 2006). } 368\end{array}$ \\
\hline 2001 & 20,000 & $\begin{array}{l}\text { James, Colin, "National," in Raymond Miller (ed.), New } \\
\text { Zealand Government and Politics. (Auckland: Oxford } \\
\text { University Press, 2006). n375 }\end{array}$ \\
\hline 2001 & 22,000 & $\begin{array}{l}\text { Young, Audrey, "Brash plotting to extend magic run." New } \\
\text { Zealand Herald, } \\
\text { http://www.nzherald.co.nz/section/1/story.cfm?c id=1\& } \\
\text { objectid=3561003, } 2004 \text { (accessed: } 7 \text { June } 2007 \text { ) }\end{array}$ \\
\hline 2002 & 26,000 & $\begin{array}{l}\text { New Zealand Press Association, "National supporters urged to } \\
\text { overturn the polls," New Zealand Herald, } \\
\text { http://www.nzherald.co.nz/feature/story.cfm?c_id=774\& } \\
\text { objectid=2050667, } 2002 \text { (accessed: } 7 \text { June 2007) }\end{array}$ \\
\hline 2002 & 7,000 & $\begin{array}{l}\text { Salmond, Rob, "Choosing Candidates: Labour and National in } \\
\text { 2002," in Jonathan Boston, Stephen Church, Stephen } \\
\text { Levine, Elizabeth McLeay, and Nigel S. Roberts (eds.), } \\
\text { New Zealand Votes: The General Election of 2002, } \\
\text { (Wellington: Victoria University Press, 2003). } 196\end{array}$ \\
\hline 2004 & 44,000 & $\begin{array}{l}\text { Young, Audrey, "Brash plotting to extend magic run." New } \\
\text { Zealand Herald, } \\
\text { http://www.nzherald.co.nz/section/1/story.cfm?c id=1\& } \\
\text { objectid=3561003, } 2004 \text { (accessed: } 7 \text { June } 2007)\end{array}$ \\
\hline 2005 & 40,000 & $\begin{array}{l}\text { Berry, Ruth, "National members bid to soften race policy," New } \\
\text { Zealand Herald, } \\
\text { http://www.nzherald.co.nz/topic/story.cfm?c id= }=58 \& \text { obj } \\
\text { ectid=10347251, } 2005 \text { (accessed: } 7 \text { June } 2007 \text { ) }\end{array}$ \\
\hline 2005 & 30,000 & $\begin{array}{l}\text { Milne, Jonathan, "Nervous Labour faces tough battle to return to } \\
\text { power," New Zealand Herald, } \\
\text { http://www.nzherald.co.nz/section/1/story.cfm?c id=1\& } \\
\text { objectid=10117265, } 2005 \text { (accessed: } 7 \text { June } 2007 \text { ) }\end{array}$ \\
\hline 2005 & $\begin{array}{l}\text { Between } \\
10,000 \\
\text { and } \\
17,000\end{array}$ & $\begin{array}{l}\text { O'Connor, Teresa, "Maori Party 'biggest in the country'," New } \\
\text { Zealand Herald, } \\
\text { http://www.nzherald.co.nz/section/1/story.cfm?c id=1\& } \\
\text { objectid=10128011, 2005 (accessed: } 7 \text { June } 2007 \text { ) }\end{array}$ \\
\hline
\end{tabular}




\begin{tabular}{|l|l|c|}
\hline 2005 & 20,000 & $\begin{array}{c}\text { Subject C, Interview with Gregory R. Stephens, 12 November } \\
2007\end{array}$ \\
\hline 2005 & 30,000 & $\begin{array}{r}\text { Young, Audrey, "Remarkable rise of Don Brash," New Zealand } \\
\text { Herald, } \\
\text { http://www.nzherald.co.nz/section/1/story.cfm?c id=1\& } \\
\text { objectid=10337228, 2005 (accessed: 7 June 2007) }\end{array}$ \\
\hline 2006 & 20,000 & $\begin{array}{c}\text { Edwards, Bryce, "Backdoor funding affects democracy," New } \\
\text { Zealand Herald, } \\
\text { http://www.nzherald.co.nz/topic/story.cfm?c_id=221\&o } \\
\text { bjectid=10401160\&pnum=0, 2006 (accessed: 7 June } \\
\text { 2007) }\end{array}$ \\
\hline 2007 & 20,000 & $\begin{array}{l}\text { Collins, Simon, "Private donations make up small percentage of } \\
\text { funding," New Zealand Herald, } \\
\text { http://www.nzherald.co.nz/section/story.cfm?c_id=280\& } \\
\text { objectid=10481111\&ref=rss, 2007 (accessed: 8 } \\
\text { December 2007) }\end{array}$ \\
\hline
\end{tabular}




\section{Bibliography}

Allern, Elin H., and Karina Pedersen. "The Impact of Party Organisational Changes on Democracy." West European Politics 30, no. 1 (2007): 68-92.

Appleton, Andrew M., and Daniel S. Ward. "Party Response to Environmental Change: A Model of Organizational Innovation." Party Politics 3, no. 3 (1997): 341-362.

Arseneau, Therese. "The Defining Features of the 2005 Election: A 'Glass Ceiling' and 'Constitutional Innovation'." In Stephen Levine and Nigel S. Roberts (eds.) The Baubles of Office: The New Zealand General Election of 2005, 419-441. Wellington: Victoria University Press, 2007.

Atkinson, Neill. Adventures in Democracy: A History of the Vote in New Zealand. Dunedin: Otago University Press, 2003.

Bale, Tim, and Nigel S. Roberts. "Plus ça change...? Anti-Party Sentiment and Electoral System Change: A New Zealand Case Study." Commonwealth and Comparative Politics 40, no. 2 (2002): 1-20.

Banducci, Susan. "The Changing Nature of Representation in New Zealand: Evaluations of the Party List." Paper presented at the Elections and Democracy Conference, Lisbon, 28 February 2002.

Barker, Fiona. "Negotiating with New Zealand First: A Study of its Coalition Agreements with National and with Labour." In Jonathan Boston, Stephen Levine, Elizabeth McLeay and Nigel S. Roberts (eds.) From Campaign to Coalition: New Zealand's First General Election Under Proportional Representation, 247-273. Palmerston North: Dunmore Press, 1997. . "Party Policy Positioning: The New Zealand Labour Party in Opposition 19901996." MA, Victoria University of Wellington, 1998.

Barker, Fiona, Jonathan Boston, Stephen Levine, Elizabeth McLeay, and Nigel S. Roberts. "An Initial Assessment of the Consequences of MMP in New Zealand." In Matthew Soberg Shugart and Martin P. Wattenberg (eds.) MixedMember Electoral Systems: The Best of Both Worlds?, 297-322. Oxford: Oxford University Press, 2001.

Barker, Fiona, and Elizabeth McLeay. "How Much Change? An Analysis of the Initial Impact of Proportional Representation on the New Zealand Parliamentary Party System " Party Politics 6, no. 2 (2000): 131-154.

Bean, Clive. "Party Leaders and Local Candidates." In Martin Holland (ed.) Electoral Behaviour in New Zealand, 141-168. Auckland: Oxford University Press, 1992.

Beller, Dennis C., and Frank P. Belloni, eds. Faction Politics: Political Parties and Factionalism in Comparative Perspective. Santa Barbara and Oxford: ABCClio, 1978.

Berry, Ruth. "All National candidates to be on list." New Zealand Herald, http://www.nzherald.co.nz/topic/story.cfm?c id=467\&objectid=10127743, 2005 (accessed: 15 November 2007).

"Brash's knife hovers over Maori offices." New Zealand Herald, http://www.nzherald.co.nz/section/1/story.cfm?c id=1\&objectid=10342927, 2005 (accessed: 30 October 2007).

. "National members bid to soften race policy." New Zealand Herald, http://www.nzherald.co.nz/topic/story.cfm?c id=58\&objectid=10347251， 2005 (accessed: 7 June 2007). 
- "National spreads short, sharp message." New Zealand Herald, http://www.nzherald.co.nz/section/1/story.cfm?c id=1\&objectid=10328610, 2005 (accessed: 30 October 2007).

"No bite in Brash's baloney." New Zealand Herald, http://www.nzherald.co.nz/section/1/story.cfm?c id=1\&objectid=10127538, 2005 (accessed: 24 October 2007).

Blyth, Mark, and Richard S. Katz. "From Catch-all Politics to Cartelisation: The Political Economy of the Cartel Party." West European Politics 28, no. 1 (2005): 33-60.

Boston, Jonathan, Stephen Church, and Hilary Pearse. "Explaining the Demise of the National-New Zealand First Coalition." Australian Journal of Political Science 39, no. 3 (2004): 585-603.

Boston, Jonathan, Stephen Levine, Elizabeth McLeay, and Nigel S. Roberts. New Zealand Under MMP: A New Politics? Auckland: Auckland University Press, 1996.

Boston, Jonathan, and Elizabeth McLeay. "Forming the First MMP Government: Theory, Practice and Prospects." In Jonathan Boston, Stephen Levine, Elizabeth McLeay and Nigel S. Roberts (eds.) From Campaign to Coalition: New Zealand's First General Election Under Proportional Representation, 207-246. Palmerston North: Dunmore Press, 1997.

Bowler, Shaun, and David M. Farrell. "Conclusion: The Contemporary Election Campaign." In Shaun Bowler and David M. Farrell (eds.) Electoral Strategies and Political Marketing, 223-235. New York: St. Martin's Press, 1992.

. "The Study of Election Campaigning." In Shaun Bowler and David M. Farrell (eds.) Electoral Strategies and Political Marketing, 1-23. New York: St. Martin's Press, 1992.

Boyd, David. "Party Candidate Selection Procedures and Objectives under MMP." MA, University of Auckland, 1996.

Brash, Don. "National opts for party vote only in Maori seats." New Zealand National Party, http://www.national.org.nz/Article.aspx?ArticleID=3217, 2004 (accessed: 13 November 2007).

"Nationhood." New Zealand National Party, http://www.national.org.nz/Article.aspx?ArticleID=1614, 2004 (accessed: 26 October 2007).

- "New Zealand Needs A Change Of Government." Scoop, http://www.scoop.co.nz/stories/PA0506/S00625.htm, 2005 (accessed: 25 October 2007).

Brownlee, Gerry. "A great time to be in National." Scoop, http://www.scoop.co.nz/stories/PA0503/S00418.htm, 2005 (accessed: 25 October 2007).

Budge, Ian. "Identifying Dimensions and Locating Parties: Methodological and Conceptual Problems." In Richard S. Katz and William Crotty (eds.) Handbook of Party Politics, 422-434. London: Sage, 2006.

Carey, John M., and Matthew Soberg Shugart. "Incentives to Cultivate a Personal Vote: A Rank Ordering of Electoral Formulas." Electoral Studies 14, no. 4 (1995): 417-439.

Carty, R. Kenneth. "Parties as Franchise Systems: The Stratarchical Organizational Imperative." Party Politics 10, no. 1 (2004): 5-24.

Catherall, Sarah. "National politics on the cards for QC Judith Ablett-Kerr." New Zealand

Herald, 
http://www.nzherald.co.nz/organisation/story.cfm?o id=500483\&objectid=101 22111, 2005 (accessed: 9 November 2007).

Catt, Helena. "New Zealand." In Pippa Norris (ed.) Passages to Power: Legislative Recruitment in Advanced Democracies, 137-157. Cambridge: Cambridge University Press, 1997.

. "Frail Success?: The New Zealand Experience Of Electing Women." Paper presented at the European Consortium for Political Research, Edinburgh 2003.

Chief Electoral Office. "2002 General Election Split Voting Statistics." Elections New Zealand, http://2002.electionresults.govt.nz/splitvotes/excel/SplitVotingAllElectorates.xls , 2002 (accessed: 10 December 2007).

. "2005 General Election Split Voting Statistics - All Electorates." Elections New Zealand, http://2005.electionresults.govt.nz/elect-splitvote-Overall.html, 2005 (accessed: 10 December 2007).

Christensen, Ray. "The Effect of Electoral Reforms on Campaign Practices in Japan: Putting New Wine into Old Bottles." Asian Survey 38, no. 10 (1998): 986-1004.

Church, Stephen. "Lights, Camera, Election: The Televsion Campaign." In Jonathan Boston, Stephen Church, Stephen Levine, Elizabeth McLeay and Nigel S. Roberts (eds.) Left Turn: The New Zealand General Election of 1999, 105-126. Wellington: Victoria University Press, 2000.

Clark, Philip J. "The Impact of MMP on Political Party Electorate Organisations: A Case Study of National In Banks Peninsula." MA, University of Canterbury, 1998.

Collins, Simon. "Private donations make up small percentage of funding." New Zealand

Herald, http://www.nzherald.co.nz/section/story.cfm?c id=280\&objectid=10481111\&re $\mathrm{f}=\mathrm{rss}, 2007$ (accessed: 8 December 2007).

Colomer, Josep M. "It's Parties That Choose Electoral Systems (or, Duverger's Laws Upside Down)." Political Studies 53, no. 1 (2005): 1-21.

Cousins, Margaret, and Elizabeth McLeay. "Leaflets, Letterboxes and Litter: Candidates and their Campaigns." In Jonathan Boston, Stephen Levine, Elizabeth McLeay and Nigel S. Roberts (eds.) From Campaign to Coalition: The 1996 MMP Election, 83-95. Palmerston North: Dunmore Press, 1997.

Cox, Gary W., Frances M. Rosenbluth, and Michael F. Thies. "Electoral Reform and the Fate of Factions: The Case of Japan's Liberal Democratic Party." British Journal of Political Science 29, no. 1 (1999): 33-56.

_. "Electoral Rules, Career Ambitions, and Party Structure: Comparing Factions in Japan's Upper and Lower Houses." American Journal of Political Science 44, no. 1 (2000): 115-122.

Crotty, William, ed. Approaches to the Study of Party Organization. Boston: Allyn and Bacon, 1968.

Crotty, William, Donald Freeman, and Douglas Gatlin, eds. Political Parties and Political Behavior. Boston: Allyn and Bacon, 1966.

Dalton, Russell J. "The Decline of Party Identifications." In Russell J. Dalton and Martin P. Wattenberg (eds.) Parties without Partisans: Political Change in Advanced Industrial Democracies, 19-37. Oxford: Oxford University Press, 2000 .

Dalziel, Lianne. "General Debate Speech, 11 September 2002." In Hansard, 447-448: New Zealand House of Representatives, 2002. 
de Malmanche, Brett. "Appendix 8: 'Events, My Dear Boy': The Political Scene, 20022005." In Stephen Levine and Nigel S. Roberts (eds.) The Baubles of Office: The New Zealand General Election of 2005, 553-569. Wellington: Victoria University Press, 2007.

Debnam, Geoffrey. "Overcoming the Iron Law? The Role of Policy Committees of the New Zealand Labour Party." In Kay Lawson (ed.) How Political Parties Work: Perspectives from Within, 55-72. Westport, CT: Praeger, 1994.

Denemark, David. "New Zealand: The 1987 Campaign." In Shaun Bowler and David M. Farrell (eds.) Electoral Strategies and Political Marketing, 163-182. New York: St. Martin's Press, 1992.

. "Thinking Ahead to Mixed-Member Proportional: Party Strategies and Election Campaigning under New Zealand's New Electoral Law." Party Politics 2, no. 3 (1996): 409-420.

. "Choosing MMP in New Zealand: Explaining the 1993 Electoral Reform." In Matthew Soberg Shugart and Martin P. Wattenberg (eds.) Mixed-Member Electoral Systems: The Best of Both Worlds?, 70-95. Oxford: Oxford University Press, 2001.

_. "Electoral Change, Inertia and Campaigns in New Zealand: The First Modern FPP Campaign in 1987 and the First MMP Campaign in 1996." Party Politics 9, no. 5 (2003): 601-618.

Deschouwer, Kris. "Political Parties as Multi-Level Organizations." In Richard S. Katz and William Crotty (eds.) Handbook of Party Politics, 291-300. London: Sage, 2006.

Douglas, Roger. "How We Did It." In Margaret Clark (ed.) For the Record: Lange and the Fourth Labour Government, 56-59. Wellington: Dunmore Press, 2005.

Downs, Anthony. An Economic Theory of Democracy. Boston: Addison-Wesley, 1985 [1957].

Dulio, David A. "Party Crashers? The Relationship Between Political Consultants and Political Parties." In Richard S. Katz and William Crotty (eds.) Handbook of Party Politics, 348-358. London: Sage, 2006.

Duverger, Maurice. Political Parties: Their Organization and Activity in the Modern State. Translated by Barbara North and Robert North. New York: John Wiley \& Sons, 1967 [1951].

Edwards, Bryce. "Political Parties in New Zealand: A Study of Ideological and Organisational Transformation." PhD, University of Canterbury, 2003.

- "Backdoor funding affects democracy." New Zealand Herald, http://www.nzherald.co.nz/topic/story.cfm?c id=221\&objectid=10401160\&pnu $\underline{\mathrm{m}=0}, 2006$ (accessed: 7 June 2007).

. "Shining a Light on Party Finance in New Zealand." Paper presented at the New Zealand Political Studies Association Conference, Wellington, 30-31 August 2007.

Electoral Commission. "General elections 1890-1993 - seats won by party." Elections New Zealand, http://www.elections.org.nz/elections/FPP seats won.html, 2005 (accessed: 10 December 2007).

_. "General elections 1996-2005 - seats won by party." Elections New Zealand, http://www.elections.org.nz/elections/article_126.html, 2006 (accessed: 10 December 2007).

Engelmann, Fredrick C. "A Critique of Recent Writings on Political Parties." The Journal of Politics 19, no. 3 (1857): 423-440. 
Epstein, Leon D., ed. Political Parties in Western Democracies. New York: Frederick A. Praeger, 1967.

"Political Parties: Organization." In David Butler, Howard R. Penniman and Austin Ranney (eds.) Democracy at the Polls: A Comparative Study of Competitive National Elections, 52-74. Washington, D.C.: American Enterprise Institute for Public Policy Research, 1981.

Espiner, Guyon. "Nat party chief criticises Govt over job losses." The Evening Post, 31 July 1998, 1.

Farrar, David. "National Candidates." Kiwiblog, http://www.kiwiblog.co.nz/2007/07/national_candidates.html, 2007 (accessed: 9 November 2007).

Farrell, David M. "Campaign Strategies and Tactics." In Lawrence LeDuc, Richard G. Niemi and Pippa Norris (eds.) Comparing Democracies: Elections and Voting in Global Perspective, 160-183. Thousand Oaks: Sage, 1996.

. Electoral Systems: A Comparative Introduction. Basingstoke, Hampshire: Palgrave, 2001.

. "Political Parties in a Changing Campaign Environment." In Richard S. Katz and William Crotty (eds.) Handbook of Party Politics, 122-133. London: Sage, 2006.

Ferrara, Federico, Erik S. Herron, and Misa Nishikawa. Mixed Electoral Systems: Contamination and its Consequences. New York and Basingstoke: Palgrave and MacMillan, 2005.

Fisher, Justin. "Economic performance or electoral necessity? Evaluating the system of voluntary income to political parties." British Journal of Politics and International Relations 2, no. 2 (2000): 179-204.

Fisher, Justin, David Denver, and Gordon Hands. "The Relative Electoral Impact of Central Party Co-ordination and Size of Party Membership at Constituency Level." Electoral Studies 25, no. 4 (2006): 664-676.

Gallagher, Michael. "Conclusion." In Michael Gallagher and Michael Marsh (eds.) Candidate Selection in Comparative Perspective: The Secret Garden of Politics, 236-283. London: Sage, 1988.

_. "Introduction." In Michael Gallagher and Michael Marsh (eds.) Candidate Selection in Comparative Perspective: The Secret Garden of Politics, 1-19. London: Sage, 1988.

Geddis, Andrew. "The General Election in New Zealand, July 2002." Electoral Studies 23, no. 1 (2004): 149-155.

—. "The Unsettled Legal Status of Political Parties in New Zealand." New Zealand Journal of Public and International Law 3, no. 1 (2005): 105-129.

- Electoral Law in New Zealand: Practice and Policy. Wellington: LexisNexis, 2007.

_. "Rethinking the Funding of New Zealand's Election Campaigns." Policy Quarterly 3, no. 1 (2007): 3-10.

Gibson, Rachel, and Robert Harmel. "Party Families and Democratic Performance: Extraparliamentary vs. Parliamentary Group Power." Political Studies 46, no. 3 (1998): 633-650.

Grafton, Tim. "National's Campaign." In Jonathan Boston, Stephen Church, Stephen Levine, Elizabeth McLeay and Nigel S. Roberts (eds.) New Zealand Votes: The General Election of 2002, 111-117. Wellington: Victoria University Press, 2003. 
Gustafson, Barry. The First 50 Years: A History of the New Zealand National Party. Auckland: Reed Methuen, 1986.

Hager, Nicky. The Hollow Men: A Study in the Politics of Deception. Nelson: Craig Potton Publishing, 2006.

Hames, Martin. Winston First: The Unauthorised Account of Winston Peters' Career. Auckland: Random House, 1995.

Harmel, Robert. "Environment and Party Decentralization: A Cross-National Analysis." Comparative Political Studies 14, no. 1 (1981): 75-99.

Harmel, Robert, Uk Heo, Alexander C. Tan, and Kenneth Janda. "Performance, Leadership, Factions and Party Change: An Empirical Analysis." West European Politics 18, no. 1 (1995): 1-33.

Harmel, Robert, and Kenneth Janda. Parties and their Environments: Limits to Reform? New York: Longman, 1982.

- "An Integrated Theory of Party Goals and Party Change." Journal of Theoretical Politics 6, no. 3 (1994): 259-287.

Harrington Jr, Joseph E., and Gregory D. Hess. "A Spatial Theory of Positive and Negative Campaigning." Games and Economic Behavior 17, no. 2 (1996): 209229.

Hawke, Gary, ed. Changing Politics? The Electoral Referendum 1993. Wellington: The Institute of Policy Studies, 1993.

Hazan, Reuven Y., and Gideon Rahat. "Candidate Selection: Methods and Consequences." In Richard S. Katz and William Crotty (eds.) Handbook of Party Politics, 109-121. London: Sage, 2006.

Hazan, Reuven Y., and Gerrit Voerman. "Electoral Systems and Candidate Selection." Acta Politica 41, no. 2 (2006): 146-162.

Heidar, Knut. "Party Membership and Participation." In Richard S. Katz and William Crotty (eds.) Hanbook of Party Politics, 301-315. London: Sage, 2006.

Heitshusen, Valerie, Garry Young, and David M. Wood. "Electoral Context and MP Constituency Focus in Australia, Canada, Ireland, New Zealand, and the United Kingdom." American Journal of Political Science 49, no. 1 (2005): 32-35.

Hide, Rodney. "ACT - Survival in Epsom." In Stephen Levine and Nigel S. Roberts (eds.) The Baubles of Office: The New Zealand General Election of 2005, 139146. Wellington: Victoria University Press, 2007.

Hine, David. "Factionalism in West European Parties: A Framework for Analysis." West European Politics 5, no. 1 (1982): 36-53.

Hopkin, Jonathan. "Bringing the Members back in? Democratizing Candidate Selection in Britain and Spain." Party Politics 7, no. 3 (2001): 343-261.

-. "Political Decentralization, Electoral Change and Party Organizational Adaptation: A Framework for Analysis." European Urban and Regional Studies 10, no. 3 (2003): 227-237.

Hopkin, Jonathan, and Caterina Paolucci. "The Business Firm Model of Party Organisation: Cases from Spain and Italy." European Journal of Political Research 35, no. 3 (1999): 307-339.

Inglehart, Ronald. Modernization and Postmodernization: Cultural, Economic, and Political Change in 43 Societies. Princeton, New Jersey: Princeton University Press, 1997.

Jackson, Keith. "Political Leadership and Succession in the New Zealand National Party." Political Science 27, no. 1 \& 2 (1975): 1-24. 
"Candidate Selection and the 1978 General Election." In Howard R. Penniman (ed.) New Zealand at the Polls: The General Election of 1978. Washington, D.C.: American Enterprise Institute for Public Policy Research, 1980.

Jackson, Keith, and Alan McRobie. New Zealand Adopts Proportional Representation: Accident? Design? Evolution? Aldershot: Ashgate, 1998.

James, Colin. "Rogernomics-Plus with Ruth." In Colin James and Alan McRobie (eds.) Turning Point: The 1993 Election and Beyond, 32-63. Wellington: Bridget Williams Books, 1993.

- "Commentary on Political Parties and Participation." In Alan Simpson (ed.) The Constitutional Implications of MMP, 178-183. Wellington: Occasional Publication No.9, School of Political Science and International Relations, Victoria University of Wellington, 1998.

- "Assessing the Issues." In Jonathan Boston, Stephen Church, Stephen Levine, Elizabeth McLeay and Nigel S. Roberts (eds.) Left Turn: The New Zealand General Election of 1999, 69-76. Wellington: Victoria University Press, 2000.

. "Two Million Voters in Search of a Rationale." In Jonathan Boston, Stephen Church, Stephen Levine, Elizabeth McLeay and Nigel S. Roberts (eds.) New Zealand Votes: The General Election of 2002, 45-58. Wellington: Victoria University Press, 2003.

. "Comment: Ten Prime Ministers." Political Science 56, no. 2 (2004): 5-10.

. "National." In Raymond Miller (ed.) New Zealand Government and Politics, 366-376. Auckland: Oxford University Press, 2006.

. "A Contest of Values or a Contest of Wills? Factors and Issues in the 2005 Election." In Stephen Levine and Nigel S. Roberts (eds.) The Baubles of Office: The New Zealand General Election of 2005, 50-61. Wellington: Victoria University Press, 2007.

—. "Ruth Amid the Alien Corn." Paper presented at the Bolger Years: The Seventh Parliamentary Conference, Wellington, 27-28 April 2007.

Johansson, Jon. "Leadership and the Campaign." In Jonathan Boston, Stephen Church, Stephen Levine, Nigel S. Roberts and Elizabeth McLeay (eds.) New Zealand Votes: The General Election of 2002, 59-74. Wellington: Victoria University Press, 2003.

. "Orewa and the Rhetoric of Illusion." Political Science 56, no. 2 (2004): 111129.

Johnston, Richard. "Issues, Leaders, and the Campaign." In Jack Vowles, Peter Aimer, Susan Banducci and Jeffrey Karp (eds.) Voters' Victory? New Zealand's First Election Under Proportional Representation, 65-80. Auckland: Auckland University Press, 1998.

Johnston, Ron, and Charles Pattie. "Switching and Splitting: Local Contexts and Campaigns from Intentions to the Ballot Box - New Zealand 1999." Journal of Elections, Public Opinion and Parties 14, no. 1 (2004): 40-71.

Joyce, Steven. "National to send out a million 'Taxathon' pamphlets." Scoop, http://www.scoop.co.nz/stories/PO0508/S00061.htm, 2005 (accessed: 31 October 2007).

_ . "National - The Road to Recovery." In Stephen Levine and Nigel S. Roberts (eds.) The Baubles of Office: The New Zealand General Election of 2005, $105-$ 114. Wellington: Victoria University Press, 2007.

Karp, Jeffrey. "Incentive to Mobilise? The Effects of Proportional Representation on Party Activity in New Zealand." Paper presented at the Annual Conference of 
the Pacific Northwest Political Science Association, Vancouver, 16-19 October 2003.

Karp, Jeffrey, and Susan Banducci. "Issues and Party Competition Under Alternative Electoral Systems." Party Politics 8, no. 1 (2002): 123-141.

Katz, Richard S. A Theory of Parties and Electoral Systems. Baltimore and London: The Johns Hopkins University Press, 1980.

- Democracy and Elections. New York: Oxford University Press, 1997.

. "The Problem of Candidate Selection and Models of Party Democracy." Party Politics 7, no. 3 (2001): 277-296.

Katz, Richard S., and Peter Mair. "Changing Models of Party Organization and Party Democracy: The Emergence of the Cartel Party." Party Politics 1, no. 1 (1995): 5-28.

. "Cadre, Catch-All or Cartel?: A Rejoinder." Party Politics 2, no. 4 (1996): 525-534.

Kavanagh, Dennis. "Party Democracy And Political Marketing: No Place For Amateurs?" Paper presented at the Political Communications in the Global World Conference, Mainz, 30-31 October 2003.

Kelly, Richard. "The Party Didn't Work: Conservative Reorganisation and Electoral Failure." The Political Quarterly 73, no. 1 (2002): 38-43.

. "Renew and Reorganise: Party Structures and the Politics of Reinvention." The Political Quarterly 74, no. 1 (2003): 109-115.

Kirchheimer, Otto. "The Transformation of the Western European Party Systems." In Joseph LaPalombara and Myron Weiner (eds.) Political Parties and Political Development, 177-200. Princeton: Princeton University Press, 1966.

Kirk, Judy. "Address to National Party Lower North Island Regional Conference " New Zealand National Party, http://www.national.org.nz/Article.aspx?articleId=1966, 2004 (accessed: 6 November 2007).

. "National Party President Perspective." Paper presented at the Funding of Political Parties and Election Campaigns Symposium, Wellington, 15 June 2007.

Kitschelt, Herbert. "The Internal Politics of Parties: The Law of Curvilinear Disparity Revisited." Political Studies 37, no. 3 (1989): 400-421.

Kittilson, Miki Caul, and Susan E. Scarrow. "Political Parties and the Rhetoric and Realities of Democratization." In Bruce E. Cain, Russell J. Dalton and Susan E. Scarrow (eds.) Democracy Transformed? Expanding Political Opportunities in Advanced Industrial Democracies, 59-80. Oxford: Oxford University Press, 2003.

Koole, Ruud. "Cadre, Catch-all or Cartel?: A Comment on the Notion of the Cartel Party." Party Politics 2, no. 4 (1996): 507-523.

Krauss, Ellis S., and Robert Pekkanen. "Explaining Party Adaptation to Electoral Reform: The Discreet Charm of the LDP?" Journal of Japan Studies 30, no. 1 (2004): 1-34.

Krouwel, André. "Party Models." In Richard S. Katz and William Crotty (eds.) Handbook of Party Politics, 249-270. London: Sage, 2006.

Lamare, James W., and Jack Vowles. "Party Interests, Public Opinion and Institutional Preferences: Electoral System Change in New Zealand." Australian Journal of Political Science 31, no. 3 (1996): 321-345. 
Lancaster, Thomas D. "Electoral Structures and Pork Barrel Politics." International Political Science Review/Revue Internationale de Science Politique 7, no. 1 (1986): 67-81.

LeDuc, Lawrence. "The Canadian Federal Election of 1993." Electoral Studies 13, no. 2 (1994): 163-168.

Lees-Marshment, Jennifer. "Political Marketing." In Raymond Miller (ed.) New Zealand Government and Politics, 488-498. Melbourne: Oxford University Press, 2006.

Levine, Stephen, and Nigel S. Roberts. "Surveying the Snark: Voting Behaviour in the 1996 New Zealand General Election." In Jonathan Boston, Stephen Levine, Elizabeth McLeay and Nigel S. Roberts (eds.) From Campaign to Coalition: The 1996 MMP Election, 181-197. Palmerston North: Dunmore Press, 1997. . "Voting Behaviour in 1999." In Jonathan Boston, Stephen Church, Stephen Levine, Elizabeth McLeay and Nigel S. Roberts (eds.) Left Turn: The New Zealand General Election of 2002, 161-174. Wellington: Victoria University Press, 2000.

. "Consistent Patterns and Clear Trends: Electoral Behaviour in 2002." In Jonathan Boston, Stephen Church, Stephen Levine, Elizabeth McLeay and Nigel S. Roberts (eds.) New Zealand Votes: The General Election of 2002, 309332. Wellington: Victoria University Press, 2003.

. "The Baubles of Office: Winning and Losing Under MMP." In Stephen Levine and Nigel S. Roberts (eds.) The Baubles of Office: The New Zealand General Election of 2005, 23-49. Wellington: Victoria University Press, 2007.

. "Mixed Messages: Voting Behaviour in New Zealand in 2005." In Stephen Levine and Nigel S. Roberts (eds.) The Baubles of Office: The New Zealand General Election of 2005, 359-383. Wellington: Victoria University Press, 2007.

Lijphart, Arend. Electoral Systems and Party Systems: A Study of Twenty-seven Democracies, 1945-1990 Oxford: Oxford University Press, 1994. . Patterns of Democracy: Government Forms and Performance in Thirty-Six Countries. New Haven and London: Yale University Press, 1999.

Lilleker, Darren G., and Ralph Negrine. "Professionalization: Of What? Since When? By Whom?" The Harvard International Journal of Press/Politics 7, no. 4 (2002): 98-103.

Lipset, Seymour Martin, and Stein Rokkan. "Cleavage Structures, Party Systems, and Voter Alignments." In Peter Mair (ed.) The West European Party System, 91138. Oxford: Oxford University Press, 1990.

Lipson, Leslie. The Politics of Equality: New Zealand's Adventures in Democracy. Chicago: The University of Chicago Press, 1948.

List, Kevin. "National Pushes Limits Of Campaign Spending In 2005." Scoop, http://www.scoop.co.nz/stories/HL0601/S00049.htm, 2006 (accessed: 31 October 2007).

Luke, Peter. "The trouble with ideology." The Press, 13 June 1998, 15.

_. "Nats shift stance on Maori seats." The Press, 27 November 2004, 19.

Lundell, Krister. "Determinants of Candidate Selection: The Degree of Centralization in Comparative Perspective." Party Politics 10, no. 1 (2004): 25-48.

Ma, Ngok, and Chi-keung Choy. "The Impact of Electoral Rule Change on Party Campaign Strategy: Hong Kong as a Case Study." Party Politics 9, no. 3 (2003): 347-367. 
Maddison, Sarah. "Ideas from 'Across the Ditch'? Wedge Politics in the 2005 New Zealand Election." Australian Journal of Political Science 41, no. 3 (2006): 427-435.

Mair, Peter, and Ingrid van Biezen. "Party Membership Decline in Twenty European Democracies, 1980-2000." Party Politics 7, no. 1 (2001): 5-21.

Mair, Peter, and Richard S. Katz. "Party Organisation, Party Democracy, and the Emergence of the Cartel Party." In Peter Mair (ed.) Party System Change: Approaches and Interpretations, 93-120. Oxford: Clarendon Press, 1997.

Mair, Peter, Wolfgang C. Müller, and Fritz Plasser. "Conclusion: Political Parties in Changing Electoral Markets." In Peter Mair, Wolfgang C. Müller and Fritz Plasser (eds.) Political Parties in Changing Electoral Markets, 264-274. London: Sage, 2004.

— , eds. Political Parties and Electoral Change: Party Responses to Electoral Markets. London: Sage Publications, 2004.

Mancini, Paolo. "New Frontiers in Political Professionalism." Political Communication 16, no. 3 (1999): 231-245.

Matland, Richard E. "Enhancing Women's Political Participation: Legislative Recruitment and Electoral Systems." In Julie Ballington and Azza Karam (eds.) Women in Parliament: Beyond Numbers, 93-110. Stockholm: International Institute for Democracy and Electoral Assistance, 2005.

May, John D. "Opinion Structure of Political Parties: The Special Law of Curvilinear Disparity." Political Studies 21, no. 2 (1973): 135-151.

McKenna, Megan K.L. "Can Rural Voices Effect Rural Choices? Contesting Deregulation in New Zealand's Apple Industry." Sociologia Ruralis 40, no. 3 (2000): 366-286.

McLeay, Elizabeth. "New Zealand: Parliamentary Careers and Electoral Reform." In Jens Borchet and Jürgen Zeiss (eds.) The Political Class in Advanced Democracies: A Comparative Handbook, 278-297. Oxford: Oxford University Press, 2003.

—. "Representation, Selection, Election: The 2002 Parliament." In Jonathan Boston, Stephen Church, Stephen Levine, Elizabeth McLeay and Nigel S. Roberts (eds.) New Zealand Votes: The General Election of 2002, 283-308. Wellington: Victoria University Press, 2003.

McLeay, Elizabeth, and Jack Vowles. "Redefining Constituency Representation: The Role of New Zealand MPs Under MMP." Regional and Federal Studies 17, no. 1 (2007): 71-95.

McMillan, Kate. "Winning the Metadebate: New Zealand's 2005 Televised Leaders' Debates in Comparative Perspective." In Stephen Levine and Nigel S. Roberts (eds.) The Baubles of Office: The New Zealand General Election of 2005, 211235. Wellington: Victoria University Press, 2007.

Michels, Robert. Political Parties: A Sociological Study of the Oligarchical Tendencies of Modern Democracy. Translated by Eden Paul and Cedar Paul. New York: The Free Press, 1968 [1915].

Miller, Raymond. "Labour." In Raymond Miller (ed.) New Zealand Government and Politics, 235-250. Melbourne: Oxford University Press, 2003.

. "New Zealand First." In Raymond Miller (ed.) New Zealand Government and Politics, 261-273. Melbourne: Oxford University Press, 2003.

. "Who Stood for Office, and Why?" In Jack Vowles, Peter Aimer, Susan Banducci, Jeffrey Karp and Raymond Miller (eds.) Voters' Veto: The 2002 
Election in New Zealand and the consolidation of minority government, 85-103. Auckland: Auckland University Press, 2004.

. Party Politics in New Zealand. Melbourne: Oxford University Press, 2005.

. "New Zealand's Multi-Party System: Consolidation of the Cartel Model under Proportional Representation." In Ian Marsh (ed.) Political Parties in Transition?, 218-234. Annandale: Federation Press, 2006.

Milne, Jonathan. "Nervous Labour faces tough battle to return to power." New Zealand Herald, http://www.nzherald.co.nz/section/1/story.cfm?c id=1\&objectid=10117265, 2005 (accessed: 7 June 2007).

Milne, R. S. Political Parties in New Zealand. Oxford: Clarendon Press, 1966.

Müller, Wolfgang C., and Kaare Strøm, eds. Policy, Office, or Votes? How Political Parties in Western Europe Make Hard Decisions. Cambridge: Cambridge University Press, 1999.

Mulgan, Richard. Politics in New Zealand. second ed. Auckland: Auckland University Press, 1997.

. Politics in New Zealand. third (updated by Peter Aimer) ed. Auckland: Auckland University Press, 2004.

Mussen, Dedire. "Brash challenge is 'laying groundwork for National defeat in 2008 election'." Sunday Star Times, 26 October 2003, 4.

Nagel, Jack. "New Zealand: Reform by (Nearly) Immaculate Design." In Josep M. Colomer (ed.) Handbook of Electoral System Choice, 530-543. London: Palgrave-Macmillan, 2004.

Nassmacher, Karl-Heinz. "Comparative Political Finance in Established Democracies." In Karl-Heinz Nassmacher (ed.) Foundations for Democracy: Approaches to Comparative Political Finance: Essays in Honour of Herbert E. Alexander, 933. Baden-Baden: Nomos Verglagsgesellschraft, 2001.

National Party Electoral Reform Working Party. "The Emerging Picture: Party List and Constituency Selection: Discussion Paper - Mark II." Wellington: New Zealand National Party, 1994.

New Zealand Election Study. "Campaign and Issues, 1993." New Zealand Election Study, http://www.nzes.org/exec/show/freq 1993a, 1993 (accessed: 5 September 2007).

_. "Party Preferences and Voting, 1996." New Zealand Election Study, http://www.nzes.org/exec/show/freq 1996e, 1996 (accessed: 5 September 2007).

—. "Democracy, Parties, and the Electoral System, 1999." New Zealand Election Study, http://www.nzes.org/exec/show/freq 1999b, 1999 (accessed: 5 September 2007).

—. "Democracy, Parties, and the Political System, 2002." New Zealand Election Study, http://www.nzes.org/exec/show/freq 2002b, 2002 (accessed: 5 September 2007).

—. "2005 NZES: Section B Frequencies." New Zealand Election Study, http://www.nzes.org/exec/show/freq_2005b, 2005 (accessed: 5 September 2007).

New Zealand Labour Party. "New Zealand Labour Party Constitution and Rules." Wellington, 2003.

. "New Zealand Labour Party Constitution and Rules." Wellington, 2007.

New Zealand National Party. "The National Party Handbook." Wellington, 1969. 
. "Constitution and Rules of the New Zealand National Party." Wellington, 1986.

. "Constitution and Rules of the New Zealand National Party." Wellington, 1997.

. "Constitution and Rules of the New Zealand National Party." Wellington, 1998.

"National Announces Party List." Scoop Press Release Archive, 1999.

. "General Election 2002- National Party List Ranking." Scoop, http://www.scoop.co.nz/stories/PA0206/S00251.htm, 2002 (accessed: 7 November 2007).

. "Constitution and Rules of the New Zealand National Party." Wellington, 2003.

- "English Speech: Give MPs the tools to do their job." Scoop Press Release Archive, 2003.

. "National Party overwhelmingly backs change." Scoop Press Release Archive, 2003.

. "Nats to consider critical changes." Scoop Press Release Archive, 2003.

-. "The Great NZ Taxathon." New Zealand National Party, http://www.national.org.nz/files/Taxathon small.asf, 2005 (accessed: 24 October 2007).

- "Send An e-Card." New Zealand National Party, http://www.national.org.nz/Ecards.aspx, 2005 (accessed: 24 October 2007).

New Zealand Press Association. "Heartland NZ gives National 'wake-up call' on rural policy." The Press, 11 May 1998, 9.

- "National supporters urged to overturn the polls." New Zealand Herald, http://www.nzherald.co.nz/feature/story.cfm?c id=774\&objectid=2050667, 2002 (accessed: 7 June 2007).

—. "Scrutiny of Maori smoking programme welcomed." New Zealand Herald, http://www.nzherald.co.nz/section/1/story.cfm?c id=1\&objectid=3584112, 2004 (accessed: 30 October 2007).

—. "National sets out 'disciplined' immigration plan." New Zealand Herald, http://www.nzherald.co.nz/section/1/story.cfm?c id=1\&objectid=10339908, 2005 (accessed: 24 October 2007).

Norris, Pippa, and Joni Lovenduski. "Why Parties Fail to Learn: Electoral Defeat, Selective Perception and British Party Politics." Party Politics 10, no. 1 (2004): 85-104.

O'Connor, Teresa. "Maori Party 'biggest in the country'." New Zealand Herald, http://www.nzherald.co.nz/section/1/story.cfm?c id=1\&objectid=10128011, 2005 (accessed: 7 June 2007).

O'Sullivan, Fran. "The cost of democracy." New Zealand Herald, http://www.nzherald.co.nz/feature/story.cfm?c id=774\&objectid=2049298, 2002 (accessed: 5 October 2007).

Palmer, Geoffrey, and Matthew Palmer. Bridled Power: New Zealand's Constitution and Government. fourth ed. Melbourne: Oxford University Press, 2004.

Panebianco, Angelo. Political Parties: Organization \& Power. Translated by Marc Silver. Cambridge: Cambridge University Press, 1988.

Park, Cheol Hee. "Factional Dynamics in Japan's LDP since Political Reform: Continuity and Change." Asian Survey 41, no. 3 (2001): 428-461.

Pearse, Hilary. "'No Junk Mail': The Street-Level Campaign." In Jonathan Boston, Stephen Church, Stephen Levine, Elizabeth McLeay and Nigel S. Roberts (eds.) 
Left Turn: The New Zealand General Election of 1999, 127-138. Wellington: Victoria University Press, 2000.

Peele, Gillian. "Towards 'New Conservatives'? Organisational Reform and the Conservative Party." The Political Quarterly 69, no. 2 (1998): 141-147.

Pekkanen, Robert, Benjamin Nyblade, and Ellis S. Krauss. "Electoral Incentives in Mixed-Member Systems: Party, Posts, and Zombie Politicians in Japan." American Political Science Review 100, no. 2 (2006): 183-193.

Peters vs Collinge, 2 NZLR 554 (1993).

Pomper, Gerald M. "Concepts of Political Parties." Journal of Theoretical Politics 4, no. 2 (1992): 143-159.

Rae, Douglas W. The Political Consequences of Electoral Laws. New Haven and London: Yale University Press, 1967.

Rahat, Gideon. "Intraparty Candidate Selection Methods: An Analytical Framework." Paper presented at the European Consortium for Political Research, Manheim, 26-31 March 1999.

Renwick, Alan. "Why Did National Promise a Referendum on Electoral Reform in 1990?" Political Science 59, no. 1 (2007): 7-22.

Richardson, Ruth. Making a Difference. Christchurch: Shoal Bay Press, 1995.

Roberts, Nigel S. "All Over the Place: Billboards Battles in 2002." In Jonathan Boston, Stephen Church, Stephen Levine, Elizabeth McLeay and Nigel S. Roberts (eds.) New Zealand Votes: The General Election of 2002, 270-280. Wellington: Victoria University Press, 2003.

. "Changing Spots: Political Party Billboard Battles in New Zealand in 2005." In Stephen Levine and Nigel S. Roberts (eds.) The Baubles of Office: The New Zealand General Election of 2005, 269-279. Wellington: Victoria University Press, 2007.

Robinson, Alan. "The Rise of the New Zealand National Party, 1936-1949." MA, University of New Zealand (Victoria), 1957.

Robinson, Claire. "The Party Vote, Populism and Political Advertising in 2002." In Jonathan Boston, Stephen Church, Stephen Levine, Elizabeth McLeay and Nigel S. Roberts (eds.) New Zealand Votes: The General Election of 2002, 235253. Wellington: Victoria University Press, 2003.

"DVD." In Stephen Levine and Nigel S. Roberts (eds.) The Baubles of Office: The New Zealand General Election of 2005. Wellington: Victoria University Press, 2007.

Ross, Tara. "Clark laments divisive politics." The Press, 5 March 2004, 1.

Royal Commission on the Electoral System. Report of the Royal Commission on the Electoral System: Towards a Better Democracy. Wellington: Government Press, 1986.

Rudd, Chris, Scott Connew, Phil Harris, and Matthew Parackal. "Political Advertising in the Metropolitan Newspapers." In Stephen Levine and Nigel S. Roberts (eds.) The Baubles of Office: The New Zealand General Election of 2005, 197-210. Wellington: Victoria University Press, 2007.

Rudd, Chris, and Janine Hayward. "Campaigning." In Raymond Miller (ed.) New Zealand Government and Politics, 327-337. Melbourne: Oxford University Press, 2006.

Salmond, Rob. "Choosing Candidates: Labour and National in 2002." In Jonathan Boston, Stephen Church, Stephen Levine, Elizabeth McLeay and Nigel S. Roberts (eds.) New Zealand Votes: The General Election of 2002, 192-206. Wellington: Victoria University Press, 2003. 
Sartori, Giovanni. Parties and Party Systems: A Framework for Analysis. Vol. 1. Cambridge: Cambridge University Press, 1976.

"Party Types, Organisation and Functions." West European Politics 28, no. 1 (2005 [1967]): 5-32.

Scarrow, Susan E. "The 'Paradox of Enrollment': Assessing the Costs and Benefits of Party Memberships." European Journal of Political Research 25, no. 1 (1994): 41-60.

. "Democracy within - and without - Parties: Introduction." Party Politics 5, no. 3 (1999): 275--282.

"Parties without Members?: Party Organization in a Changing Electoral Environment." In Russell J. Dalton and Martin P. Wattenberg (eds.) Parties without Partisans, 79-101. Oxford: Oxford University Press, 2001.

Scarrow, Susan E., and Burcu Gezgor. "Trends in Party Membership and Membership Participation: Smaller Parties, Different Types of Members?" Paper presented at the Midwest Political Science Association Annual Meeting, Chicago, 20-23 April 2006.

Scarrow, Susan E., Paul Webb, and David Farrell. "From Social Integration to Electoral Contestation: The Changing Distribution of Power with Political Parties." In Russell J. Dalton and Martin P. Wattenberg (eds.) Parties without Partisans: Political Change in Advanced Industrial Democracies, 129-153. Oxford: Oxford University Press, 2000.

Schlesinger, Joseph A. "On the Theory of Party Organization." The Journal of Politics 46, no. 2 (1984): 369-400.

Shugart, Matthew Soberg. ""Extreme" Electoral Systems and the Appeal of the MixedMember Alternative." In Matthew Soberg Shugart and Martin P. Wattenberg (eds.) Mixed-Member Electoral Systems: The Best of Both Worlds?, 25-51. Oxford: Oxford University Press, 2001.

Shugart, Matthew Soberg, and Martin P. Wattenberg. "Mixed-Member Electoral Systems: A Definition and Typology." In Matthew Soberg Shugart and Martin P. Wattenberg (eds.) Mixed-Member Electoral Systems: The Best of Both Worlds?, 9-24. Oxford: Oxford University Press, 2001.

Shvedova, Nadezhda. "Obstacles to Women's Participation in Parliament." In Julie Ballington and Azza Karam (eds.) Women in Parliament: Beyond Numbers, 3350. Stockholm: International Institute for Democracy and Electoral Assistance, 2005.

Siaroff, Alan. "Varieties of Parliamentarianism in the Advanced Industrial Democracies." International Political Science Review 24, no. 4 (2003): 445464.

Siavelis, Peter M. "Party and Social Structure." In Richard S. Katz and William Crotty (eds.) Handbook of Party Politics, 359-370. London: Sage, 2006.

Simpson, Alan, ed. The Constitutional Implications of MMP. Wellington: Occasional Publication No.9, School of Political Science and International Relations, Victoria University of Wellington, 1998.

Sowry, Roger. "The National Campaign: Tactics and Strategies." In Jonathan Boston, Stephen Levine, Elizabeth McLeay and Nigel S. Roberts (eds.) From Campaign to Coalition: The 1996 MMP Election, 25-32. Palmerston North: Dunmore Press, 1997.

Spratt, Amanda. "Too much culture, says Brash." New Zealand Herald, http://www.nzherald.co.nz/section/1/story.cfm?c id=1\&ObjectID =10343937, 2005 (accessed: 30 October 2007). 
Statistics New Zealand. "New Zealand: An Urban/Rural Profile." http://www.stats.govt.nz/NR/rdonlyres/A2FDF8E9-32AD-487D-AEE7040F513EE777/0/NZUrbanRuralProfile2.pdf, 2004 (accessed: 20 August 2007).

Stephens, Gregory R. "Factionalism in the New Zealand Labour and National Parties: The Challenges of Moving from a Two-Party System to a Multi-Party System." Paper presented at the New Zealand Political Studies Association Conference, Wellington, 30-31 August 2007.

Stokes, Jon. "Labour - speak Maori properly." New Zealand Herald, http://www.nzherald.co.nz/section/1/story.cfm?c id=1\&objectid=10342696, 2005 (accessed: 25 October 2007).

Strøm, Kaare. "A Behavioral Theory of Competitive Political Parties." American Journal of Political Science 34, no. 2 (1990): 565-598.

Subject A. interview with Gregory R Stephens, 15 June 2007.

Subject B. interview with Gregory R Stephens, 14 June 2007.

Subject C. interview with Gregory R Stephens, 12 November 2007.

Tan, Alexander C. "Party Change and Party Membership Decline: An Exploratory Analysis." Party Politics 3, no. 3 (1997): 363-377.

Taylor, Kevin. "New take on old jingle to push tax message." New Zealand Herald, http://www.nzherald.co.nz/section/1/story.cfm?c_id=1\&objectid=10339261, 2005 (accessed: 31 October 2007).

Taylor, Peter J. "The Case for Proportional Tenure: A Defense of the British Electoral System." In Arend Lijphart and Bernard Grofman (eds.) Choosing An Electoral System: Issues and Alternatives, 53-58. New York: Praeger, 1984.

Taylor, Peter J., and Arend Lijphart. "Proportional Tenure vs Proportional Representation: Introducing a New Debate." European Journal of Political Research 13, no. 4 (1985): 387-399.

Thompson, Geoffrey. "Preparing the Party for MMP." Paper presented at the Bolger Years: The Seventh Parliamentary Conference, Wellington, 27-28 April 2007.

Tsebelis, George. Veto Players: How Political Institutions Work. Princeton: Princeton University Press, 2002.

Tunnah, Helen. "Wanted: new Brash-pack MPs." New Zealand Herald, http://www.nzherald.co.nz/section/1/story.cfm?c id=1\&objectid=3577376, 2004 (accessed: 30 October 2007).

Vowles, Jack. "The Politics of Electoral Reform in New Zealand." International Political Science Review/Revue Internationale de Science Politique 16, no. 1 (1995): 95-115.

. "Waiting for the Realignment? The New Zealand Party System, 1972-93." Political Science 48, no. 2 (1997): 184-209.

. "Countdown to MMP." In Jack Vowles, Peter Aimer, Susan Banducci and Jeffrey Karp (eds.) Voters' Victory? New Zealand's First Election Under Proportional Representation, 12-27. Auckland: Auckland University Press, 1998.

- "Did the Campaign Matter?" In Jack Vowles, Peter Aimer, Susan Banducci, Raymond Miller and Ann Sullivan (eds.) Proportional Representation on Trial: The 1999 New Zealand General Election and the Fate of MMP, 16-33. Auckland: Auckland University Press, 2002.

. "Parties and Society in New Zealand." In Paul Webb, David Farrell and Ian Holliday (eds.) Political Parties in Advanced Industrial Democracies, 409-437. Oxford: Oxford University Press, 2002. 
"What Happened at the 1999 Election?" In Jack Vowles, Peter Aimer, Jeffrey Karp, Susan Banducci, Raymond Miller and Ann Sullivan (eds.) Proportional Representation on Trial: The 1999 New Zealand General Election and the Fate of MMP, 83-98. Auckland: Auckland University Press, 2002.

. "Estimating Change During The Campaign." In Jack Vowles, Peter Aimer, Susan Banducci, Jeffrey Karp and Raymond Miller (eds.) Voters' Veto: The 2002 Election in New Zealand and the Consolidation of Minority Government, 33-47. Auckland: Auckland University Press, 2004.

. "Patterns of Public Opinion." In Jack Vowles, Peter Aimer, Susan Banducci, Jeffrey Karp and Raymond Miller (eds.) Voters' Veto: The 2002 Election in New Zealand and the Consolidation of Minority Government, 117-133. Auckland: Auckland University Press, 2004.

. "New Zealand: The Consolidation of Reform?" In Michael Gallagher and Paul Mitchell (eds.) The Politics of Electoral Systems, 295-313. Oxford: Oxford University Press, 2005.

Vowles, Jack, and Peter Aimer. Voters' Vengeance: the 1990 Election in New Zealand and the Fate of the Fourth Labour Government. Auckland: Auckland University Press, 1993.

. "Political Leadership, Representation and Trust." In Jack Vowles, Peter Aimer, Susan Banducci, Jeffrey Karp and Raymond Miller (eds.) Voters' Veto: The 2002 Election in New Zealand and the Consolidation of Minority Government, 167-183. Auckland: Auckland University Press, 2004.

Vowles, Jack, Susan Banducci, and Jeffrey Karp. "Forecasting and Evaluating the Consequences of Electoral Change in New Zealand." Acta Politica 41, no. 3 (2006): 267-284.

Ward, Leigh J. "'Second-Class MPs'? New Zealand's Adaptation to Mixed-Member Parliamentary Representation." Political Science 49, no. 2 (1998): 125-152.

Ware, Alan. Political Parties and Party Systems. Oxford: Oxford University Press, 1996.

Watkins, Tracy. "Losing campaign cost Nats \$1m." The Dominion Post, 26 October 2002, 2.

Wilson, Margaret. "Political Parties and Participations." In Alan Simpson (ed.) The Constitutional Implications of MMP, 168-177. Wellington: Occasional Publication No.9, School of Political Science and International Relations, Victoria University of Wellington, 1998.

Wilson, Shaun, and Nick Turnbull. "Wedge Politics and Welfare Reform in Australia." Australian Journal of Politics and History 47, no. 3 (2001): 384-404.

Wood, Anthony. "The National Party." In Hyam Gold (ed.) New Zealand Politics in Perspective, 172-188. Auckland: Longman Paul, 1985.

_. Governing New Zealand. Auckland: Longman Paul, 1988.

. "The National Party." In Hyam Gold (ed.) New Zealand Politics in Perspective, 289-309. Auckland: Longman Paul, 1992.

. "National." In Raymond Miller (ed.) New Zealand Government and Politics, 251-260. Melbourne: Oxford University Press, 2003.

Young, Annabel. "Strategy, Tactics and Operations: National's Campaign." In Jonathan Boston, Stephen Church, Stephen Levine, Elizabeth McLeay and Nigel S. Roberts (eds.) Left Turn: The New Zealand General Election of 1999, 30-35. Wellington: Victoria University of Wellington, 2000. 
Young, Audrey. "Into the valley of electoral death." New Zealand Herald, http://www.nzherald.co.nz/feature/story.cfm?c id=774\&objectid=2347634, 2002 (accessed: 1 June 2007).

- "Brash plotting to extend magic run." New Zealand Herald, http://www.nzherald.co.nz/section/1/story.cfm?c id=1\&objectid=3561003, 2004 (accessed: 7 June 2007).

- "Remarkable rise of Don Brash." New Zealand Herald, http://www.nzherald.co.nz/section/1/story.cfm?c id=1\&objectid=10337228, 2005 (accessed: 7 June 2007).

Young, Audrey, and New Zealand Press Association. "Tears flow as 16 MPs say goodbye." New Zealand Herald, http://www.nzherald.co.nz/feature/story.cfm?c $\mathrm{id}=774 \&$ objectid=2347052, 2002 (accessed: 1 June 2007). 